
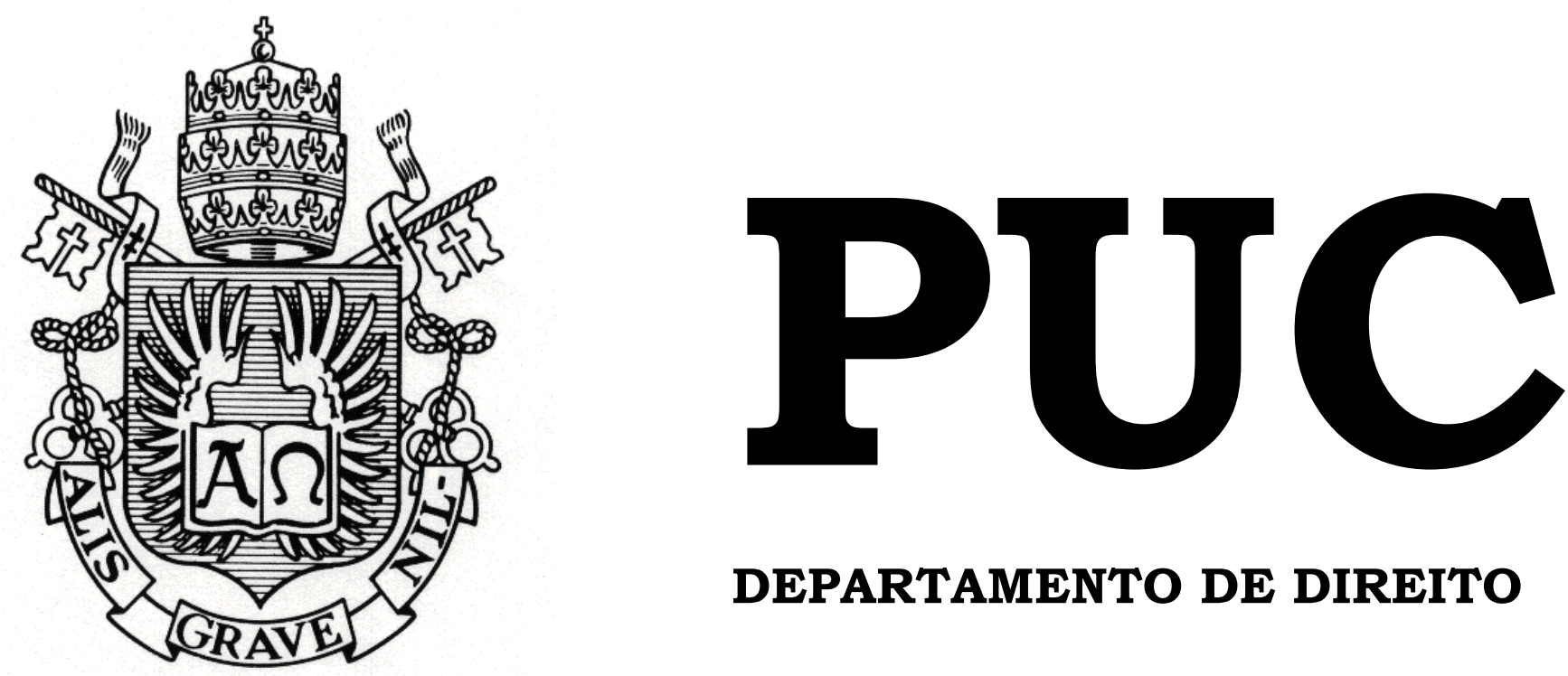

DEPARTAMENTO DE DIREITO

A Mediação como método alternativo à resolução de conflitos nos casos envolvendo ofendido e ofensor

por

Érika Pamplona Barcelos Nahid

ORIENTADORA: Samantha Pelajo

2010.1

PONTIFÍCIA UNIVERSIDADE CATÓLICA DO RIO DE JANEIRO

RUA MARQUÊS DE SÃO VICENTE, 225 - CEP 22453-900

RIO DE JANEIRO - BRASIL 


\title{
A Mediação como método alternativo à resolução de conflitos nos casos envolvendo ofendido e ofensor
}

\author{
por
}

Érika Pamplona Barcelos Nahid

Monografia apresentada ao Departamento de Direito da Pontificia Universidade Católica do Rio de Janeiro (PUC-Rio) para a obtenção do Título de Bacharel em Direito.

Orientador(a): Samantha Pelajo 


\section{DEDICATÓRIA}

Ao meu amor,

Pedro Julian

Que com seu amor e carinho incondicionais,

sempre me incentivou e me ajudou em todos os momentos.

Muito obrigado por fazer parte da minha vida. 


\section{AGRADECIMENTOS}

Agradeço aos meus pais pelo imenso amor e esforço em minha educação, me abrindo todos os caminhos para chegar até aqui, sendo para o sempre meu exemplo de carinho e dedicação.

Aos meus amados irmãos que sempre acreditaram em mim e me deram forças, sendo sempre aqueles que mais me orgulham.

Aos meus amigos pelas constantes e mais variadas demonstrações de carinho, me apoiando e aconselhando em todas as horas. 


\section{RESUMO}

O presente trabalho busca ilustrar o pouco êxito do aparato penal tradicional que se arrasta desde os primórdios até o atual sistema criminal. Diante disso, tem-se a necessidade de implementação de novos mecanismos alternativos, a fim de complementar e dar maior eficiência ao sistema retributivo criminal, obtendo-se uma melhor forma de resolução dos conflitos, em conformidade com os princípios fundamentais e normas jurídicas. A Justiça Restaurativa aparece como uma resposta a essa carência, através de sua ramificação Mediação Vítima-Ofensor.

A Mediação Penal é uma das modalidades do instituto da Mediação e tem como princípios, a participação ativa e voluntária da vítima e seu ofensor na autocomposição de uma resolução para os danos causados pelo conflito, a restauração das relações desfeitas e a assunção de culpa por parte do infrator, através da ajuda de um terceiro imparcial- o mediador- condutor deste processo.

O uso desse procedimento apresenta inúmeros resultados positivos, quais sejam: uma grande satisfação das partes, altos índices de acordo- sendo estes mais eficazescontenção da reincidência criminal e um impacto psicológico positivo sobre a vítima.

Apesar de não haver uma legislação específica, alguns institutos permitem a aplicação da Mediação Penal no ordenamento jurídico brasileiro. O uso deste método

alternativo de resolução de conflitos no país já pode ser visto, inclusive, através da criação de alguns projetos, conforme exposto nesta monografia.

\section{PALAVRAS-CHAVE}

Conflito. Sistema Retributivo. Sistema Restaurativo. Ofendido. Ofensor. Justiça Restaurativa. Mediação de conflitos. Mediação Vítima- Ofensor. Aplicação e resultados. 


\section{SUMÁRIO}

1 - INTRODUÇÃ

1.1 - A necessidade de se redefinir o sentido da pena e as concepções do sistema

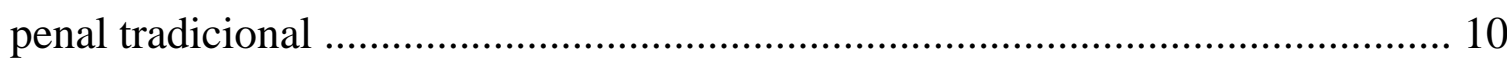

1.2 - Justiça Restaurativa como alternativa ao Sistema Penal Tradicional ........... 14

1.3 - As diferenças entre a Justiça Retributiva (tradicional) e a Justiça

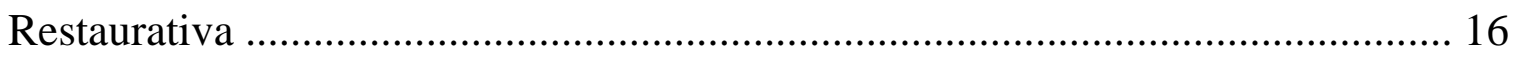

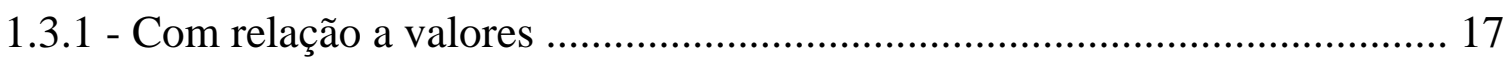

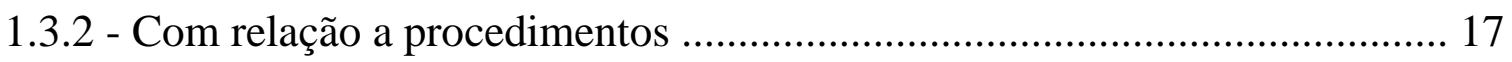

1.3.3 - Com relação aos resultados .................................................................... 18

1.3.4 - Com relação aos efeitos para a vítima ....................................................... 19

1.3.5 - Com relação aos efeitos para o ofensor ……………………………….... 19

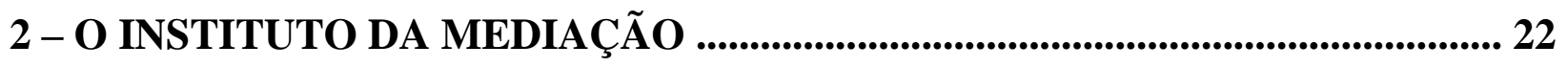

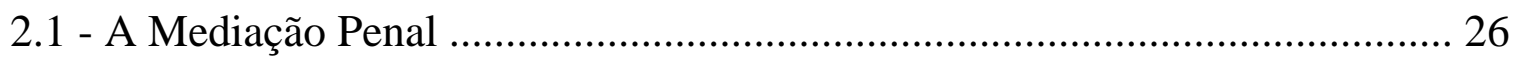

2.1.1 - Características da Mediação Penal ............................................................. 27

2.1.2 - Etapas do processo de Mediação Penal ........................................................ 32

2.1.3 - Efeitos do processo de Mediação Penal ......................................................... 36

3 - A INCIDÊNCIA DA MEDIAÇÃO PENAL NA ESFERA PROCESSUAL ...... 38

3.1 - A Mediação Penal nos casos de Ações Penais Públicas e Privadas ............. 43

3.1.1 - A Mediação Penal no que tange à suspensão condicional do processo ..... 44

3.2 - Aplicação da Mediação Penal em crimes mais graves .................................. 48

3.3 - Outras possibilidades de aplicação da Mediação Penal no processo e suas influências 
4 - CONCLUSÃO

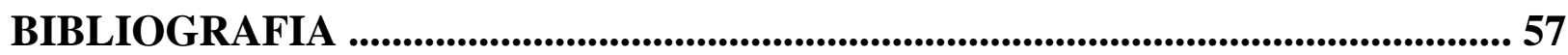

ANEXOS 


\section{1 - INTRODUÇÃO}

A criminalidade surgiu com o próprio homem, porém na sociedade primitiva não havia a presença de um sistema com princípios penais. Todo o mal que atingia aquela sociedade era entendido como conseqüências da obra divina e para repará-lo foram criadas proibições tanto religiosas, quanto sociais e políticas que acarretavam em castigos, significando uma vingança contra o ofensor. A punição dada ao infrator nesta época é conhecida atualmente como "pena". (MIRABETE, 2005, p-35)

Ao longo da história, diversos foram os meios de aplicação das penas e os princípios utilizados. A "vingança privada" foi uma delas, em que os indivíduos ou suas tribos se enfrentavam diretamente. Posteriormente, nova evolução foi presenciada com a criação da Lei de Talião, cujo intuito era impedir uma reação idêntica da vítima ao seu agressor: olho por olho, dente por dente. A Lei de Talião foi acolhida dentre outros, pelo Código de Hamurábi, lei do povo da Babilônia, provocando ordem na sociedade quanto ao tratamento dos crimes e delitos. (BITENCOURT, pp-26-27). Adotado também pelo Código de Hamurabi foi o sistema pelo qual o ofensor se livrava do castigo através da compra da sua liberdade. Ambos os sistemas apresentaram um grande avanço para Direito Penal ao limitar a ação punitiva. (MIRABETE, 2005, p-35)

No período feudal, o aparato penal era controlado pela Igreja Católica e pela divisão da sociedade em classes: clero, nobreza e camponeses. A concepção de crime e pecado nessa época eram muito próximas e até mesmo se confundiam.

O poder era absoluto, concentrado nas mãos do juiz, que detinha a faculdade de acusar, investigar, aplicar as penas e torturar o acusado. As torturas eram os chamados suplícios, nos quais o corpo era o alvo principal da repressão criminal.

Beccaria critica esta forma de sistema penal, pois além de não se definir o que é crime, as penas eram muito cruéis e por vezes o acusado/inocente, devido às torturas sofridas, acabava por confessar um crime que não cometera e paralelamente a isso, um 
acusado/culpado por resistir às torturas, não cedia à confissão de um crime que fora praticado por ele. (BECCARIA, 2005, pp. 70-71)

No entanto, entre o final do século XVIII e início do século XIX, os suplícios são eliminados, extinguindo-se a repressão sobre o corpo, tornando a punição extremamente vigiada pelo processo penal. (FOUCAULT, 2006, pp.12-14)

"A punição pouco a pouco deixou de ser uma cena. E tudo o que pudesse implicar de espetáculo desde então terá cunho negativo; e como as funções da cerimônia penal deixavam pouco a pouco de ser compreendidas, ficou a suspeita de que tal rito que dava "fecho" ao crime mantinha com ele afinidades espúrias: igualando-o, ou mesmo ultrapassando-o em selvageria, acostumando os espectadores a uma ferocidade de que todos queriam vê-los afastados, mostrando-lhes a freqüencia dos crimes, fazendo o carrasco se parecer com criminoso, os juízes aos assassinos, invertendo no último momento os papéis, fazendo do supliciado um objeto de piedade e de admiração." (FOUCAULT, 2006, pp.12-13)

Com a reforma penal, segundo Foucault a essência do direito penal passa ser a punição através da privação de liberdade do indivíduo, no sentido de reeducar e ressocializar. Vai haver uma vigilância ininterrupta da sociedade a partir das prisões legais. (2006, p- 13). A justiça criminal não deveria mais utilizar a vingança no combate ao mal, mas sim a punição. (Ibid. p-63).

"O corpo é colocado segundo essa penalidade num sistema de coação e de privação, de obrigações e de interdições. O sofrimento físico, a dor do corpo não são mais os elementos constitutivos da pena. O castigo passou a ser a arte das sensações insuportáveis a uma economia dos direitos suspensos. " (FOUCAULT, 2006, p- 14)

“... um exército inteiro de técnicos veio substituir o carrasco, anatomista imediato do sofrimento: os guardas, os médicos, os capelães, os psiquiatras, os psicólogos, os educadores; por sua simples presença ao lado do condenado, eles cantam à justiça o louvor de que ela precisa: eles lhe garantem que o corpo e a dor não são os objetos últimos de sua ação punitiva." (Ibid.).

Assim, o discurso da reforma penal passou a defender a igualdade perante a lei, não havendo distinções entre ricos e pobres na hora de punir. No entanto, permanece até os dias de hoje a contradição da predominância das punições sobre os pobres, apesar da defesa da igualdade de todos perante a lei ${ }^{1}$.

\footnotetext{
${ }^{1}$ Há uma diferenciação no direito estrangeiro quanto ao princípio da igualdade perante a lei e o da igualdade na lei. O primeiro entendimento é baseado em uma idéia de igualdade a todos aqueles que aplicam as leis, ou seja, é uma isonomia formal, devendo haver o emprego fiel das normas jurídicas gerais aos casos concretos por mais que se tenha como resultado uma discriminação. Já o segundo entendimento defende a idéia de igualdade na lei, tanto aos
} 
Partia-se da idéia de que era necessário codificar todas as práticas ilícitas, individualizando as penas, para que as infrações fossem bem definidas e punidas com segurança, impedindo a tolerância à impunidade. Além disso, a punição passou a olhar para o futuro, tendo como função principal a prevenção, porém, esse objetivo não foi alcançado, como será tratado a seguir.

"As primeiras leis e os primeiros magistrados nasceram da necessidade de coibir as desordens geradas pelo despotismo físico dos indivíduos; essa foi a finalidade instituidora da sociedade e esse fim primário sempre foi mantido, na realidade ou na aparência, à frente de todos os códigos, ainda que destruidores." (BECCARIA, 2006, pp. 57-58)

A obrigação de punir passou a vigorar no sistema penal e, apesar das transformações ao longo do tempo, a racionalidade penal moderna manteve seu fundamento teórico nas teorias da pena, conferindo-a o papel de principal freio às condutas desviadas e impondo ao Estado, detentor do monopólio penal, a obrigação pragmática de punir. (PIRES, p-39-60).

Segundo Cezar Bitencourt, apesar do intuito preventivo da pena, ela é majoritariamente entendida pela doutrina como "um mal que deve ser imposto ao autor de um delito para que expie sua culpa”. (2004, p-71).

legisladores quanto àqueles que as aplicam, ou seja, as diferenciações que não são permitidas pela Constituição, não devem ser utilizadas na aplicação das normas jurídicas gerais. A Constituição Federal Brasileira é contrária as definições supracitadas, pois o entendimento consolidado pela doutrina e pela jurisprudência é a de que a igualdade perante a lei segue o sentido de ser para todos, aplicável não só ao o legislador mas também aos aplicadores da lei. (DA SILVA, 01.2001, p-218-225).

No direito penal, a igualdade perante a lei deve seguir o sentido de que todos que cometem um crime previsto pelo sistema normativo devem sofrer as mesmas sanções e se submeter à mesma legislação. Salienta-se, no entanto, que a realidade que se vê é outra pois, diante das desigualdades sociais presenciadas nos dias de hoje, os menos abastados acabam sofrendo uma maior rigidez da justiça penal em relação aos indivíduos dotados de melhores condições financeiras, divergindo do princípio da isonomia previsto na Constituição Federal Brasileira de $1988 \mathrm{em}$ seu artigo $5^{\circ}$. (Ibid.)

Artigo $5^{\circ}$, caput, Constituição Federal Brasileira: "Todos são iguais perante a lei, sem distinção de qualquer natureza, garantindo-se aos brasileiros e aos estrangeiros residentes no País a inviolabilidade do direito à vida, à liberdade, à igualdade, à segurança e à propriedade , nos termos seguintes", 


\section{1 - A NECESSIDADE DE SE REDEFINIR O SENTIDO DA PENA E AS CONCEPÇÕES DO SISTEMA PENAL TRADICIONAL}

De acordo com Leonardo Sica há uma necessidade de se recriar o sentido preventivo da pena, pois apesar desta ser a sua natureza, essa finalidade vem sendo burlada por punições determinadas, o que gera dor, privações na vítima e rotulações de condutas criminosas, bem como castigos exemplificativos com a finalidade de desestimular práticas ilícitas e também demonstrar a regularidade do sistema criminal. (2007, pp.137-138).

Nos dias atuais, devido ao crescimento desenfreado da criminalidade, ao fracasso das políticas públicas e, conseqüentemente, ao aumento do medo social, os indivíduos passaram a buscar, de forma cada vez mais premente, respostas e soluções, no intuito de conter essa realidade. E foi a partir dessa mobilização que as penas passaram a ter um aumento considerável em sua quantidade, notando-se uma repercussão sobre as decisões penais, cada vez mais autoritárias e duras, tornando inofensivo o princípio da legalidade ${ }^{2}$.

Segundo Leonardo Sica: "A justiça penal coisifica ofensores e vítimas, transformando-os em meros e repetidos réus e testemunhas, de um paradigma que pressupõe que cada caso pode e deve ser igual aos casos anteriores, daí decisões pasteurizadas, súmulas vinculantes, etc."

"Decisões arbitrárias são servidas como solução, quando nada solucionam. Não só os aspectos pessoais e situacionais são ignorados: mesmo a argumentação e a interpretação de cada caso seguem esteriótipos, traçando um padrão ajustado ao status quo e amoldado a um discurso neutro e irresponsável quanto aos seus custos sociais, escorado no pretexto do legalismo ("prendo porque a lei manda..."). E, quando essa decisão pode resultar na aplicação de uma pena privativa de liberdade (ou seja: imposição de sofrimento), assume contornos nefastos e francamente aviltantes da dignidade da pessoa humana." (2007, p-31).

Estudos em diversas áreas já comprovaram o pouco êxito do atual modelo de justiça, notadamente ao que concerne a contenção da violência social. Logo, faz-se necessária uma redefinição das concepções do sistema tradicional individualizando cada

\footnotetext{
${ }^{2}$ Princípio da Legalidade: O princípio da legalidade, previsto no artigo $5^{\circ}$, XXXIX da Constituição da República Federal Brasileira de 1988: Art $5^{\circ}$ XXXIX CF: "não há crime sem lei anterior que o defina, nem pena sem prévia cominação legal" foi acolhido pelo Direito Penal Brasileiro, que o introduziu em seu artigo $1^{\circ}$
} 
caso, não levando em conta apenas as conseqüências do crime para a sociedade sob uma percepção meramente estatal, mas também direcionando o foco da resolução do conflito, a partir da infração penal para vítima e autor do fato.

Para o professor argentino Ulf Christian Eiras Nordenstahl, ocorre uma burocratização da resposta processual ao conflito, buscando-se generalizar soluções para problemas diversos, em detrimento de se especificar cada delito. A generalização da intervenção estatal e a tentativa de rápidas soluções diante de conflitos tão distintos resultam em uma insatisfação dos cidadãos, por não acreditarem no sucesso dessas intervenções do Estado no atual sistema penal. (2005, p-28).

Somado a isso, e tendo em vista que o crime nunca se extinguirá, pois de acordo com Durkheim, "o crime é saudável, necessário e útil à transformação das sociedades, uma vez que estas nunca atingirão uma situação imutável de equilíbrio total", são necessários, urgentemente, novos mecanismos para resolução profícua dos conflitos.

Com isso, apesar do sistema penal ter enfrentado diversas reformas, a realidade é que ele se mantém obsoleto e bastante ineficaz, sendo certo, também, que a criminalidade cresce desenfreadamente, sem que as medidas presentes na realidade penal sejam de fato satisfatórias para combater, restaurar e prevenir essa reputação do contexto de violência.

A seguir, os dois casos que, apesar de se distanciarem por cerca de quatro séculos, ilustram a ineficácia do aparato penal, que mesmo tendo vivido inúmeras transformações, mantêm-se desde os primórdios até o atual sistema: 


\section{Imagem I: Babilônia, Século XVII a.C.}

"Um indivíduo aplica pessoalmente a pena destinada a outro, integrante da mesma classe social, agredindo-o no exercício regular do direito que lhe confere a ducentésima cláusula do Código de Hamurabi: "se alguém parte os dentes de um outro, de igual condição, deverá ter partidos os seus dentes”. Sem prejuízo, terá ele assegurada uma compensação pecuniária, de acordo com a cláusula 203 do mesmo diploma legal: "se um nascido livre espanca um nascido livre de igual condição, deverá pagar uma mina”.

\section{Imagem II: Brasil, início do Século XXI d.C.}

“Seu” João diz que aceita a proposta de composição civil sugerida por representante do Estado que conhecera há exatos três minutos, a fim de não correr o risco de ser processado por violação do disposto no artigo 129, "caput”, do Código Penal. Para isso terá que pagar um valor destinado ao conserto da prótese de sua companheira, três parcelas de $R \$ 30,00$, que deverá depositar no banco oficial. Dona Maria, que, três meses antes, em um agitado plantão policial, solicitou providências contra o companheiro que a agredira, providências estas que se resumiram à lavratura de termo circunstanciado, sai do Fórum sem entender muito bem o que se passou. De tudo que foi dito naquela audiência, entendeu que deveria retornar dali a quinze dias para levantar, no banco oficial, a primeira parcela de $R \$ 30,00$. Quatro meses depois voltaria à presença do representante do Estado para confirmar que não recebeu as duas últimas parcelas. Acrescentou, porém, que não pretendia tomar nenhuma providências legal, já que o companheiro, com problemas crônicos de alcoolismo, ainda morava com ela e, no fim das contas, aquele valor seria destinado à aquisição das provisões básicas do lar. Apesar de saber que o problema não tinha sido tratado nem resolvido, e que provavelmente voltaria a ter problemas, diz que "Seu" João melhorou seu comportamento depois da audiência e saiu do Fórum orientada a retornar à Delegacia de Polícia caso tivesse novos problemas. ' (DE VITTO, 2005, pp- 46-48) 
Outro dado importante que contribui mais uma vez para a confirmação do fracasso do sistema penal são os números referentes à população prisional no Brasil. Durante o período da edição da Lei Número 9.099/95 foi feito um estudo a respeito da quantidade de internos. Em 1995, o número era de 148.760 e em 2003, chegou a 308.304. Salienta-se que nesse mesmo período analisado foi triplicado o número de vagas do sistema prisional e quadruplicado o número de estabelecimentos prisionais, no entanto, a capacidade das prisões permaneceu negativa em 50\%. Logo, conclui-se que o aumento de todo o aparato carcerário jamais será suficiente para atender à demanda do sistema prisional ${ }^{3}$. (DE VITTO, 2005, pp-41-42)

A partir desses dados, é possível analisar o baixo grau de efetividade da atual intervenção penal do Estado, baseada no encarceramento. Isto posto, deve ser desmitificada a visão de grande parte da sociedade de que a pena é um fim em si mesma, devendo ser voltada para a pacificação social. (DE VITTO, 2005, pp-41-42).

Desse modo, em conjunto com as transformações constantes do sistema penal, " $a$ ressocialização, prevenção, redução dos efeitos da vitimização, educação, empoderamento ${ }^{4}$ e humanização do conflito '”(AZEVEDO, 2005, p-136) são procurados através de novos métodos que dêem bons proventos para resolução de conflitos, dando mais eficiência ao sistema retributivo criminal.

Portanto, diante de tanta agressividade e opressão na resolução de disputas, os mecanismos alternativos na área penal aparecem como uma forma de complementar o sistema tradicional, criando novos meios de gestão de conflitos em conformidade com as normas jurídicas e princípios fundamentais. As buscas por soluções alternativas ou complementares aos mecanismos criminais tradicionais, sobretudo ao retributivo, vêm

\footnotetext{
3 Segundo dados do Departamento Penitenciário Nacional do Ministério da Justiça, em 1995 havia 309 estabelecimentos prisionais, que disponibilizavam 65.883 vagas, restando um déficit de 82.877 na capacidade carcerária. Em 2003 havia 1.262 estabelecimentos prisionais, que disponibilizavam 179.489 vagas, restando um déficit de 128.815 vagas. (DE VITTO, p-50)

${ }^{4}$ Empoderamento consiste na redescoberta pessoal e capacidades das partes de lidar com o conflito, readquirindo autonomia, reconstruindo a autoestima e aumentando sua participação. De acordo com André Gomma: “... empoderar uma parte é fazer com que ela adquira consciência das suas próprias capacidades e qualidades..." (AZEVEDO, 2009, p. 145)
} 
encontrando nas práticas restaurativas um encaminhamento possível. Segundo Leonardo Sica, "não adianta apenas reduzir a área de intervenção penal e mexer no "tamanho", do aparato punitivo, é necessário mexer em sua forma." (2007, p-10).

\section{2 - JUSTIÇA RESTAURATIVA COMO ALTERNATIVA AO SISTEMA PENAL TRADICIONAL}

Diante da enorme e crescente insegurança social e criminalidade que é vista nos dias de hoje ficam claros os fortes indícios da necessidade de mudanças do sistema penal. Neste contexto, a Justiça Restaurativa se apresenta como uma alternativa tanto para a sociedade quanto para o Estado, no sentido de possibilitar um leque maior de opções em resposta ao crime. (SLAKMON; DE VITTO; PINTO, p-13).

"A Justiça Restaurativa representa um novo paradigma aplicado ao processo penal, que busca intervir de forma efetiva no conflito, exteriorizado pelo crime e restaurar as relações que foram abaladas a partir desse evento.",

"O modelo de Justiça Restaurativa busca intervir positivamente em todos os envolvidos no fenômeno criminal. Pretende, destarte, tocar a origem e causa daquele conflito, e a partir daí possibilitar o amadurecimento pessoal do infrator, redução dos danos aproveitados pela vítima e comunidade, com notável ganho na segurança social." (DE VITTO, p- 48).

Uma das mais conceituadas definições de Justiça Restaurativa é a aquela descrita pelo ECOSOC (Conselho Econômico e Social) como sendo "todo o programa que se vale de processos restaurativos para atingir resultados restaurativos" Este conceito está presente na Resolução 2002/12, emitida pelo ECOSOC e no relatório do Instituto Latino Americano das Nações Unidas para Prevenção do Delito e Tratamento do DelinquenteILANUD (Instituto Latino-Americano das Nações Unidas para Prevenção do Delito e Tratamento do Delinqüente), sendo inclusive reconhecido pela ONU (Organização das Nações Unidas).

De acordo com Carlos Vasconcelos, os mecanismos restaurativos se caracterizam pela busca da reconstrução do diálogo entre vítimas e ofensores, com a ajuda de um terceiro imparcial, objetivando a elaboração conjunta de uma solução para o conflito. 
Ressalta-se que em determinados casos é possível a participação de outros indivíduos ou membros da comunidade dentro deste processo. (VASCONCELOS, 2008, p-127).

Conforme a análise feita anteriormente, o crime é considerado como a prática por um indivíduo de um fato típico reconhecido pela normatividade penal como tal, ou seja, é uma violação aos bens jurídicos protegidos pelo Estado. Paralelamente a esta idéia, a Justiça Restaurativa diverge quanto a visão tradicional de crime, pois passam a ser reconhecidos os valores da infração, isto é, a conduta ilícita praticada é entendida como um dano provocado a si mesmo, ao próximo e a comunidade. (BERISTAIN, 2000).

Contudo, ressalta-se que não é proposta a abolição do sistema penal ou sua substituição por outro modo de controle social e sanção, mas, sim, a busca de um sistema penal que seja justo e eficaz para todos: vítima, ofensor e comunidade. $\mathrm{O}$ objetivo é que todos em conjunto possam recompor os danos causados pelo conflito, sendo desnecessário o desgaste e violência de todo o processo penal, ou melhor, busca-se oportunizar as possibilidades dos protagonistas ${ }^{5}$ do conflito resolverem a questão que os envolve. (EIRAS NORDENSTAHL, pp-27-30).

Assim, a finalidade da Justiça Restaurativa seria aquela definida por John Braithwaite: um instrumento para aperfeiçoar o funcionamento da justiça formal, no intuito de aprimorar os institutos dos órgãos estatais no combate a violação das leis e da ordem, com a finalidade de dar eficiência e humanidade à Justiça Penal. Ademais, essas práticas restaurativas por permitirem a participação dos envolvidos na solução do caso, quando geram resultados positivos, substituem outras medidas mais custosas, além de serem aceitas com freqüência, como mais legítimas e incentivadoras do respeito à lei. (BRAITHWAITE, 2002).

Ou seja, é buscado um sistema em que prevaleçam os interesses concretos da vítima em prevalência aos do Estado, pois tanto o ofensor quanto a vítima requer

\footnotetext{
${ }^{5}$ Vítima e ofensor.
} 
demandas estatais no processo. O primeiro através da intervenção do poder público diante da violação do bem protegido e o segundo, para que não seja vitimado também pelo sistema judicial por não ter tido a oportunidade de participar efetivamente na resolução do conflito que o envolve. Portanto, a saída poderia ser encontrada na possibilidade do encontro da vítima com o seu ofensor e a sua positiva responsabilização na resolução do conflito, gerando diretrizes importantes para o futuro. (BERISTAIN, 2000).

Com isso, tanto ofensor quanto a vítima pretendem uma solução concreta para o conflito que os envolve. A aplicação deste processo além de possibilitar reparos materiais, pode restabelecer as relações e a confiança das partes afetadas com crime. Assim, dentro desses aspectos, a Justiça Restaurativa como instrumento de aperfeiçoamento da administração da Justiça estaria auxiliando na mudança da atual visão negativa que se tem do Poder Judiciário.

Essa diferenciação entre o atual sistema penal analisado até o momento e a justiça restaurativa proposta será esclarecida no subitem a seguir de forma mais detalhada.

\section{3 - AS DIFERENÇAS ENTRE A JUSTIÇA RETRIBUTIVA (TRADICIONAL) E A JUSTIÇA RESTAURATIVA}

Ambos os institutos da Justiça Retributiva e Justiça Restaurativa são complexos e ricos em conceitos que abordam o mesmo assunto. No entanto, não se misturam nem se confundem, mas se opõem em todas as suas estruturas e aplicações (frisando que a intenção da Justiça Restaurativa não é eliminar a anterior, mas complementá-la). O estudo a ser apresentado é obra do autor Renato Sócrates Gomes Pinto, publicada em seu artigo “Justiça Restaurativa é possível no Brasil?", que fora dividido em tópicos, e serão aqui respeitados, com o intuito único de preservar sua idéia e finalidade. 


\subsection{1 - COM RELAÇÃO A VALORES:}

A Justiça Retributiva faz um uso dogmático do Direito Penal Positivo, aplicando o conceito jurídico normativo ao Crime, por considerá-lo uma ação praticada contra o bem maior protegido pelo Estado, a sociedade. Em contrapartida, a Justiça Restaurativa critica o sistema penal tradicional, propondo a aplicação daquela como alternativa a este, de forma a dar um tratamento realístico ao crime, como sendo um ato que traumatiza a vítima, causando-lhe danos.

Quanto ao ofensor, a Justiça Restaurativa por ser culturalmente flexível, tolerante e respeitar as diferenças, defende a idéia de que deve haver a assunção da responsabilidade pela infração cometida, buscando a restauração numa dimensão social, compartilhada coletivamente e voltada para o futuro, dando primazia ao interesse das pessoas envolvidas no fato e a própria comunidade, formando as bases de uma Justiça Criminal e Social participativa, comprometida com a inclusão

Por outro lado, ao ofensor na justiça retributiva é imposta a culpabilidade individual voltada para o passado, resultando na sua estigmatização e dando ênfase ao monopólio do Estado na Justiça Criminal (Sociedade, representada pelo Estado, o Centro). Há uma indiferença do Estado quanto às necessidades do infrator, vítima e comunidade afetados, por ter uma postura de excludente e uma cultura única.

\subsection{2 - COM RELAÇÃO A PROCEDIMENTOS:}

A Justiça Retributiva é dotada de procedimentos e linguagens tanto formais quanto complexas, com rituais solenes e públicos e processos decisórios sob a competência de Autoridades Policiais, Delegados, Promotores, Juízes e Profissionais do Direito (considerados os atores principais de todo esse procedimento), cujo intuito é de dar garantias ao sistema em uma única dimensão. Além disso, trata-se de um processo 
contencioso e contraditório, ou seja, havendo algum tipo de discussão em juízo, independente da vontade de uma das partes, sua entrada será quase que obrigatória, tendo em vista que a ação penal é indisponível em praticamente todos os casos.

Já em se tratando de Justiça Restaurativa, segue o Principio da Oportunidade, obedecendo as características da voluntariedade ${ }^{6}$ quanto a participação dos envolvidos. $O$ processo decisório neste caso é informal $^{7}$ e dotado de confidencialidade ${ }^{8}$, com a participação comunitária das pessoas envolvidas (vítima, infrator e comunidade) dandolhe a característica de multiplicidade em sua dimensão.

\subsection{3 - COM RELAÇÃO AOS RESULTADOS}

Na Justiça Retributiva, a tutela penal de bens e interesses é feita com a condenação do infrator, tendo a pena como função prevenir de maneira geral e especial. Ela busca focar no ofensor, intimidando-o ao não cometimento de novos crimes e protegendo assim a sociedade. As penas podem ser privativas de liberdade, restritivas de direito e multa. No entanto, o que se vê nos dias atuais foge ao objetivo citado anteriormente, diante de um regime carcerário desumano e cruel, penas desatentas à proporcionalidade e razoabilidade, bem como a ineficácia das penas alternativas, como exemplo o pagamento de cestas básicas ou prestação de serviços à comunidade. Como resultado tem-se uma ressocialização secundária, que leva a um isolamento, desamparo e desintegração da vítima e ofensor, provocando um resultado que diverge do almejado: uma paz social com tensão.

Na Justiça Restaurativa há uma abordagem do crime e suas conseqüências, focando nas relações entre as partes, com o intuito restaurativo, de inclusão da vitima e assunção de responsabilidade espontânea por parte do ofensor. Para a vítima o processo

\footnotetext{
${ }^{6}$ As definições desses elementos encontram-se respectivamente, nas páginas, 22, 28 e 23 deste trabalho.

${ }^{7}$ Idem.

${ }^{8}$ Idem.
} 
busca a reparação do trauma moral e dos prejuízos emocionais, enquanto que para o infrator o objetivo é o pedido de desculpas, reparação do erro cometido, restituição e prestação de serviços comunitários. Este processo permeia os princípios da proporcionalidade e razoabilidade quanto às obrigações assumidas no acordo restaurativo, tendo como prioridades a reintegração do infrator, da vítima e a aquisição de uma paz social com dignidade.

\subsection{4 - COM RELAÇÃO AOS EFEITOS PARA A VÍTIMA}

Na Justiça Retributiva, a vítima ocupa um lugar subsidiário no processo, não tendo participação ativa, nem proteção, recebendo quase que nenhuma assistência psicológica, social, econômica ou jurídica do Estado, provocando sua frustração e ressentimento com o sistema.

Na Justiça Restaurativa, a vítima ocupa o centro do processo, com o papel e voz ativa; participação e controle sobre o que se passa. Da mesma forma, recebe assistência, afeto, restituição de perdas materiais e reparação da infração que sofreu. Conseqüentemente há ganhos positivos, com a supressão das necessidades individuais e coletivas da vítima e da comunidade.

\subsection{5 - COM RELAÇÃO AOS EFEITOS PARA O OFENSOR}

Na Justiça Retributiva o infrator é punido pelo Estado ao invés de ser efetivamente responsabilizado pela infração que cometeu, não sendo consideradas suas necessidades, mas apenas suas faltas e má formação. $\mathrm{O}$ ofensor tem rara participação e poucas informações sobre o processo, sendo desestimulado e mesmo inibido a dialogar com a vítima, comunicando-se com o sistema apenas através de seu advogado. 
Na Justiça Restaurativa, o infrator é visto pelo processo com potencialidade de responsabilizar-se pelos danos e conseqüências, suprindo também suas necessidades. Sua participação ativa e direta no processo, interagindo com a vítima e a comunidade, possibilita uma sensibilização com o trauma ocasionado, tendo a chance de desculpar-se. Além disso, o ofensor é informado sobre os fatos do processo restaurativo e das conseqüências do fato para a vítima e comunidade, vendo-se envolvido e acessível, o que contribui para a decisão do caso.

Cabe ressaltar que a Justiça Restaurativa assume diferentes formas em sua composição, a fim de promover seus valores, variando quanto ao número de participantes, aos procedimentos utilizados e à qualidade de intervenção do terceiro imparcial.

\author{
Algumas dessas modalidades encontradas na Justiça Restaurativa são ${ }^{9}$ a mediação \\ vítima-ofensor (Victim Offender Mediation), a conferência (conferencing), os círculos de
}

9

- Mediação Penal - A Mediação Penal é todo processo que permite ao ofendido e ao ofensor participar ativamente, (a partir do livre consentimento de ambos), da solução das dificuldades resultantes do delito, com a ajuda de um terceiro independente, o mediador. (Recomendación 99 del Comité de Ministros del Consejo de Europa - União Européia).

- Conferências - Esse processo envolve o ofensor e a vítima em longas conversas sobre o crime e suas consequiências. Esse instrumento especialmente utilizado quando se deseja dar foco ao suporte que familiares, amigos e outros membros da comunidade podem oferecer ao ofensor, tanto no cumprimento de condutas acordadas com a vítima e com a comunidade, como na mudança de seu comportamento. Representantes do Estado podem estar presentes nesse processo de diálogo facilitado por um terceiro imparcial que deverá conduzi-lo de maneira a balancear o atendimento das necessidades de ambas as partes, ofensor e vítima.

- Círculos de Construção de Consenso - Inspirados em comunidades indígenas, esses círculos de conversa e de construção de consenso envolvem um número maior de pessoas - vítimas, ofensores, seus familiares, a comunidade e os operadores do Direito. Os círculos incluem a presença do juiz e a construção consensual da sentença para o delito. A utilização desses círculos de construção e monitoramento de observâncias transcende hoje o seu emprego a questões relativas a delitos. Estes círculos vêm sendo utilizados em processos de diálogo que envolvem construção de consenso em questões comunitárias e institucionais.(ALMEIDA, acesso em 09/05/2010)

A construção de consenso é um exemplo de processo colaborativo, ou seja, dotado de forma particular que define sua atuação e a postura participativa de seus atores.

Ressalta-se que processo colaborativo é baseado no diálogo cooperativo e na construção de consenso geralmente coordenados por uma equipe de mediadores que, eleita pelas partes envolvidas, com elas estabelece contatos individuais e conjuntos - reuniões privadas e reuniões plenárias - auxiliando-as desde a eleição de seus representantes até o aprendizado necessário para participarem de fóruns negociais dessa natureza. Esta equipe desenha o processo de diálogo, o coordena e mantém-se disponível tanto para acompanhar sua implantação quanto para o seu monitoramento.(ALMEIDA, acesso em 12/05/2010) 
pacificação (peacemaking circles), círculos decisórios (sentencing circles), a restituição (restitution), entre outros. (AZEVEDO, 2005, p-135.)

Contudo, no estudo realizado será tratado apenas da mediação vítima-ofensor, como instrumento da justiça restaurativa, sua aplicabilidade e repercussão sobre a pena.

Antes de entrar em um estudo mais aprofundado da mediação penal será analisado brevemente o instituto de mediação, uma vez que, a mediação penal é apenas uma das diversas modalidades que abrange o gênero da mediação. (CARNEIRO, 2007).

Restituição - a restituição é definida como o pagamento pelo ofensor em face do dano que causou à vítima. Essa restituição pode ser tanto na forma monetária quanto em serviços prestados pelo ofensor à vítima. 


\section{2 - O INSTITUTO DA MEDIAÇÃO}

A mediação é um processo voluntário, confidencial, não adversarial e autocompositivo para a solução de controvérsias, visando à prevenção ou recomposição dos pontos de divergência que levaram as partes ao conflito.

É possível identificar três elementos básicos para o processo de mediação: a existência de partes em conflito, uma clara contraposição de interesses e um terceiro neutro capacitado a facilitar a busca pelo acordo, chamado de mediador. (PINHO, 2008, p- 241-248)

As partes podem ser: pessoas físicas, jurídicas, entes despersonalizados, (desde que identificável seu representante ou gestor) ou menores ${ }^{10}$ (desde que assistidos por seus pais). (Ibid.)

O processo de mediação é tido como voluntário, pois é baseado na autonomia da vontade; são as partes envolvidas no conflito que decidem se participam ou não; elas não sofrem qualquer tipo de imposição, participam do processo por livre e espontânea vontade e convicção de que o método poderá ser eficaz na resolução de sua lide.

“(...) a Mediação é recurso para ser eleito por quem está disponível para atuar com boa fé e a rever as posições anteriormente adotadas nas tentativas de resolução do desacordo; por quem preferir participar diretamente da solução a ser eleita e dela ser autor; por quem não identificar instrumento outro de resolução que melhor atenda sua demanda; por quem pretender celeridade e sigilo e quiser ter controle sobre o processo negocial e seus procedimentos; e por quem prezar a relação pessoal ou de convivência com aquele que litiga ou dela não puder prescindir." (ALMEIDA, acesso em 15/04/2010)

Com relação à participação dos mediandos ${ }^{11}$ ela é não adversarial, pois são coresponsáveis na solução da disputa, diferentemente do que ocorre nos processos

\footnotetext{
${ }^{10}$ A mediação aplicada aos casos de conflitos juvenis e escolares, funcionando de forma preventiva à participação de adolescentes em atividades criminosas.

${ }^{11}$ partes envolvidas no conflito.
} 
adversariais, em que um terceiro decidirá quem está certo, por exemplo, no caso dos processos administrativos, judiciais ou arbitrais. (VASCONCELOS, 2008, p-37).

A responsabilidade pela construção das decisões cabe às partes envolvidas no conflito, por isso, a mediação também é vista como mecanismo autocompositivo. Com o auxílio de um terceiro imparcial, o mediador, as partes serão ajudadas na identificação de interesses comuns, complementares e divergentes para a obtenção de uma solução consensual.

Não é dever do mediador decidir pelas partes, mas sim auxiliá-las a enxergar os obstáculos e removê-los, chegando ao acordo, ou à redução do conflito a um nível de melhor convívio entre as partes. O dever do mediador é de gerar confiança no processo e nas pessoas, para que as partes possam em conjunto reconstruir suas relações.

Por isso, a prática da Mediação requer do mediador qualificação e aperfeiçoamento, exigindo uma constante melhora de suas atitudes, habilidades profissionais e um conhecimento e treinamento específico de técnicas próprias.

Ressalta-se, também, que o mediador deve ser dotado de imparcialidade, não the sendo permitido favorecer qualquer uma das partes. Além disso, deve possuir credibilidade, sendo independente, honesto e coerente, bem como ter sido escolhido ou aceito livremente pelas partes.

Quanto ao elemento de confidencialidade de informações dentro do processo de mediação será assinado um termo de comprometimento da equipe de mediação, com a finalidade de manter o sigilo em relação a todos os temas tratados durante o processo, garantindo aos mediandos que tudo o que fora discutido não poderá ser usado como indício ou prova no processo penal. Esse comprometimento de sigilo gera um sentimento de confiança entre as partes do conflito, abrindo mais possibilidades de revelarem com maior facilidade todas as informações importantes acerca do conflito. 
Salienta-se, também, que no processo de mediação, desde que as partes do conflito estejam de acordo, é possível o acompanhamento de seus advogados ou de qualquer outra pessoa. A presença do advogado junto às partes, dentro ou fora do processo, é fortemente indicada, por exercerem a função de assessores jurídicos em defesa dos interesses legítimos de seus clientes, extinguindo qualquer tipo de dúvida que possa surgir e garantindo que o acordo seja legalmente viável.

"A mediação é tida como forma de pacificação social e restabelecimento da normalidade nas relações privadas e públicas que se encontram com uma "conflituosidade retirada'" ou que já explodiram em demandas distribuídas em Juízo". (FILHO; WEBER, 2008, p- 13).

De acordo com Humberto Pinho, dentre os principais benefícios da mediação, destaca-se: a celeridade e eficácia de resultados, redução do desgaste emocional e do custo financeiro, a garantia de privacidade e sigilo, redução da duração e reincidência de litígios, facilitação da comunicação e promoção de ambientes cooperativos, transformação das relações e melhoria dos relacionamentos. (PINHO, 2008 p-241-292).

Com relação às fases do processo de mediação, ao contrário do que ocorre no procedimento tradicional, não há como identificá-las, uma vez que se trata de um desenrolar altamente variável, por conta não só do envolvimento pessoal das partes, mas também da forma de como o mediador conduzirá o processo, não sendo possível prever o seu desenvolvimento de uma maneira determinada. (AZEVEDO, 2009, p-83)

"A mediação é um trabalho artesanal. Cada caso é único. Demanda tempo, estudo, análise aprofundada das questões sob os mais diversos ângulos. O mediador deve se inserir no contexto emocional-psicológico do conflito. (...)

(...) É um processo que pode se alongar por semanas, com inúmeras sessões, inclusive com a participação de co-mediadores, estando as partes, se assim for de seu desejo, assistidas a todo tempo por seus advogados, devendo todos os presentes anuírem quanto ao procedimento utilizado e à maneiro como as questões são postas na mesa para exame. ”(PINHO, 2008, p-248).

Ao tratar dos dispositivos legais que abarcam a mediação, é possível encontrá-los em diversos países, no entanto, no Brasil, essa normatividade da mediação ainda é bastante embrionária. Em âmbito nacional, têm-se um Projeto de Lei n o 4.827/98, 
regulando o tema e diplomas infralegais, quais sejam o Código de Ética da Mediação e o Regulamento Modelo (CONIMA).

O CONIMA (Conselho Nacional das Instituições de Mediação e Arbitragem) é uma associação civil, sem fins lucrativos, criada para dar as bases de atuação e velar pela ética de mediadores, árbitros e instituições especializadas em mediação e arbitragem civil.

O supracitado Projeto de Lei propõe a inclusão da mediação paraprocessual nos conflitos de natureza cível. Essas mediações poderão ser prévias ou incidentais em relação ao respectivo processo judicial na justiça comum.

"A mediação prévia será opcional, mas a mediação incidental deverá ser obrigatória no processo de conhecimento, salvo algumas hipóteses especificadas no Projeto de Lei. Os prazos prescricionais ficarão suspensos na fase de mediação. $O$ juiz do feito homologará por sentença os respectivos termos de mediação. Segundo o Projeto de Lei, os mediadores devem comprovar a sua idoneidade e aptidão, devendo ser capacitados e indicados por entidades especializadas $e$ cadastrados perante o respectivo Tribunal." (VASCONCELOS, 2008, p-167)

Em âmbito estadual, o Ato Executivo TJ Número 5555, de 10/12/2009 (ESTADUAL), instala o CENTRO DE MEDIAÇÃO DO FORUM CENTRAL DA COMARCA DA CAPITAL, com competência para atender os casos encaminhados pelos Juízes de Direito das Varas de Família da Comarca da Capital; o Ato Executivo TJ Número 1597, de 15/04/2010 (ESTADUAL), instaura dezesseis novos centros de mediação, que passam a atender aos processos encaminhados pelos Juízes de Direito em exercício na respectiva área atendida pelo fórum regional ou comarca, bem como a Resolução do TJ/ ORGÃO ESPECIAL n 19, de 17/12/2009 (ESTADUAL), que define no Estado do Rio de Janeiro a mediação e sua aplicação dentro dos processos a que se destina.

Isto posto, verifica-se que a mediação busca soluções criativas, através da clara identificação das causas que levaram ao conflito, das responsabilidades individuais, dos aspectos positivos da relação no passado, das potencialidades e ganhos, destacando sempre o lado benéfico e prospectivo. Além disso, a recuperação dos laços entre as partes 
leva a um aumento da probabilidade de cumprimento espontâneo do acordo e manutenção das relações que haviam sido rompidas.

Sendo assim, após a realização do estudo sobre as características e aplicabilidades da mediação de maneira generalizada, o próximo passo será a analise com mais profundidade a mediação penal como instrumento da Justiça Restaurativa, suas aplicabilidades e repercussão sobre pena.

\section{1 - A MEDIAÇÃO PENAL}

Após a breve análise do instituto da mediação, foi possível perceber suas diversas modalidades de apresentação, como, por exemplo: a familiar, a comunitária, a comercial e a Mediação Penal, objeto de estudo desta obra.

A Mediação Penal permite ao ofendido e ao ofensor voluntariamente, em um ambiente seguro e estruturado, participar de maneira ativa na solução do conflito que os envolve, restaurando as relações e reconstruindo o que foi afetado pela infração penal, com a ajuda de um terceiro independente, o mediador. A aplicação deste sistema apresenta resultados bastante positivos às partes e a toda a comunidade.

“A mediação penal é um processo cujos princípios ressaltam a participação direta dos principais
envolvidos no ato ofensivo, a restauração da vítima elou comunidade vitimada, a
responsabilização direta do ofensor pelo dano causado e o envolvimento de toda a comunidade
na restauração tanto da vítima quanto do ofensor, suprindo algumas falhas do processo judicial
hodierno e complementando o sistema de justiça criminal." (TIAGO, 2007, p-210)

A Mediação Penal, apesar de nem sempre resultar em um acordo, dá a possibilidade de se pensar um tipo de resposta baseado nos preceitos da justiça restaurativa $^{12}$, dando oportunidade ao ofensor de responsabilizar-se por suas ações ao enfrentar a vítima e, também, permitindo uma maior assistência, compensação e participação do ofendido no processo.

\footnotetext{
12 “Apesar da mediação penal ser um dos institutos da Justiça Restaurativa, ela permanece sendo espécie do gênero autocompositivo denominado de 'mediação' - seguindo as características basilares destas." (AZEVEDO, 2007, pp-135- 151)
} 
O papel do mediador é de extrema importância no processo de Mediação Penal, ele é o condutor do processo, sendo necessário o uso de diversas técnicas e recursos, pois dará auxílio às partes em conflito antes e durante o momento do encontro, tentando facilitar a difícil interação entre a vítima e ofensor, afirmando os efeitos restaurativos do processo e garantindo a segurança física e emocional. Deve ficar bem claro aos envolvidos que o mediador não atuará em momento algum como juiz, não sendo de sua competência realizar qualquer tipo de julgamento.

"Aquele que precisa fazer uso de instrumentos para o desempenho exitoso de uma determinada atividade, profissional ou não, deve saber reunir um conjunto de ferramentas que lhe sejam úteis para o exercício de sua arte ou ofício (Novo Aurélio 1999). Ferramentas reunidas,é preciso habilidade para eleger com adequação aquela que deve ser utilizada a cada momento e para manuseá-la com a propriedade que a situação exige." (ALMEIDA, acesso em 01/06/2010)

"A principio, a eleição adequada e o manuseio apropriado das ferramentas tendem a proporcionar eficácia e efetividade ao resultado." (ALMEIDA, acesso em $01 / 06 / 2010)$

As partes, dentro do processo de Mediação Penal atuarão ouvindo atentamente e sem interrupções uma à outra, utilizando uma linguagem não agressiva e trabalhando em conjunto para encontrar as soluções necessárias para a resolução e restauração do conflito que as cercam. (AZEVEDO, 2007, p-31).

"Diante da complexidade da matéria penal, a mediação deve ser desenvolvida sem julgamento, sem rotulação, sem permitir que se vitimize e sem vitimizar, sem castigos, sem buscar a verdade de ambas as partes, tudo isso embasado nas formas sutis dos relatos construídos, na relação espontânea, nas palavras usadas, na comunicação silenciosa das partes e no valor real e legal que o conflito requer, levando os mesmos a encontrarem uma perspectiva nova que atenda as suas necessidades reais e atuais. " (ARSÊNIO, acesso em 10/03/2010).

\subsection{1 - CARACTERÍSTICAS DA MEDIAÇÃO PENAL}

A mediação vítima-ofensor possui diversas características intrínsecas que a distingue dos demais tipos de mediação. As mediações cíveis são alguns exemplos; nestas, há aparentemente interesses que se contrapõem e grande dificuldade em haver pedidos reciprocos. Já na mediação vítima-ofensor, o objetivo é estabelecer o diálogo 
entre as partes, com ênfase na restauração da vítima, assunção de culpa por parte do ofensor- possibilitando também que este relate as circunstâncias e consequiências do crime no seu modo de ver - e na recuperação das perdas morais, patrimoniais e afetivas. (AZEVEDO, 2007, pp-135-151)

Conforme citado anteriormente, pôde-se ver que a mediação penal possui características próprias, apesar de ser uma modalidade do sistema de mediação. De acordo com professor argentino Ulf Eiras Nordenstahl, o processo de mediação penal deve abarcar as seguintes características: voluntariedade, confidencialidade, imparcialidade, informalidade, interdisciplinaridade. (NORDENSTAHL, 2005, p-59)

Ressalta-se que a maioria das características citadas pelo professor Ulf, já foi tratado anteriormente, quando realizado o estudo das características e aplicabilidades do instituto da mediação, a exceção das duas últimas. Para melhor compreendê-las, será feito uma breve explicação acerca de cada uma.

A informalidade é tida dentro deste processo devido a sutileza das formas, a liberdade de ação das partes, se contrapondo ao rigor do processo penal tradicional. (NORDENSTAHL, 2005, pp-71-72). No entanto, essa característica não deve ser confundida com a ausência de procedimentos, pois o processo de mediação penal possui diversas fases, atos coordenados logicamente, que devem ser seguidos de maneira cronológica para a obtenção de uma melhor comunicação entre as partes. (AZEVEDO, 2007, p-19).

O que ocorre na Mediação Penal é criar um ambiente confortável às partes, fazendo com que se sintam em um ambiente seguro e ao mesmo tempo acolhedor, tendo como condutor, o mediador, que se utilizará das ferramentas do instituto para encaminhar o processo.

A interdisciplinaridade também é encontrada, devido à complexidade dos casos passíveis de mediação, sendo necessária a aplicação de técnicas, métodos e 
conhecimentos de cada ciência para a resolução do conflito, ou seja, há a necessidade de uma equipe de mediação com a capacidade de combinar e convergir diferentes pontos de vista. (NORDENSTAHL, 2005, pp-67-71).

"A divisão das ferramentas em grupos temáticos - etapas do processo, ferramentas procedimentais, ferramentas de comunicação e de negociação - vem atender a uma necessidade didático-pedagógica.(...) Caixa de Ferramentas é uma metáfora usualmente empregada na prática da Mediação para designar o conjunto de técnicas e procedimentos utilizado na dinâmica do processo."(ALMEIDA, acesso em 01/06/2010)

De acordo com André Gomma, uma das maiores características da Mediação e também da Mediação Vítima-infrator, está na expectativa de empoderamento ${ }^{13}$ das partes, com o objetivo de dar-lhes a oportunidade de autocompor a resolução do conflito em que se encontram e o reconhecimento em conjunto dos interesses e necessidades que as cercam, buscando uma aproximação verdadeira e uma humanização do conflito pela empatia $^{14} \cdot(2009, \mathrm{p}-57)$

Cabe destacar também, que a Mediação Vítima-Ofensor apresenta diferenciações quanto à outras modalidades de mediação. Essa afirmação comprova-se, pois a Mediação Penal ressalta a restauração da vítima, responsabilização do ofensor e recuperação das perdas morais, patrimoniais e afetivas, enquanto que outras formas desse instituto são destinadas precipuamente ao acordo.

O estudo realizado por André Gomma,estabeleceu com mais detalhes as diferenciações e peculiaridades da Mediação Penal em comparação a outras modalidades de mediação e será exposto a seguir para uma melhor compreensão do tema.

O autor salienta que as comparações feitas são meramente exemplificativas, pois foram baseadas em procedimentos de mediação vítima-ofensor, seguindo as diretrizes de

\footnotetext{
13 "Empoderamento" é a tradução do termo em inglês empowerment significa a busca pela restauração do senso de valor e poder da parte para que esta esteja apta a melhor dirimir futuros conflitos. "(AZEVEDO, 2009, p-57).

${ }^{14}$ Empatia: através dos instrumentos de mediação aplicados para resolução da disputa há uma aproximação real das partes, gerando confiança e comprometimento recíproco e conseqüente humanização do conflito (Ibid. p-23). A empatia se dá quando o indivíduo se coloca no lugar do outro dentro daquela relação.
} 
algumas obras doutrinárias ${ }^{15}$ acerca do tema e na experiência do Grupo de Pesquisa e Trabalho em Arbitragem, Mediação e Negociação da Faculdade de Direito da Universidade de Brasília (GT Arbitragem). (2007, p- 34).

Em conformidade com o estudo supracitado as mediações voltadas ao acordo e centradas no ofensor, direcionam-se ao termo composição civil de danos, com menos oportunidade para comunicações diretas sobre o impacto integral do crime na vítima, na comunidade ou no próprio infrator. Não há um encontro prévio com as partes em separado antes da sessão de mediação. Esta pode durar em regra, de 10 a 15 minutos.

Nesse caso, as vítimas não podem optar pelo foro ou local em que serão realizadas as sessões, no intuito de sentirem-se mais confortáveis e seguras para o encontro com o ofensor. Da mesma forma, se a vítima quiser a participação de outras pessoas, não é dada essa opção, apenas lhes é apresentada uma solicitação escrita para comparecimento ao encontro de mediação. Normalmente, não há preparação acerca desse procedimento e do que ocorrerá em seu desenrolar.

O mediador ou facilitador nesse caso é agente público e descreverá a ofensa ou o crime e posteriormente o ofensor terá a oportunidade de se manifestar. O papel da vítima restringe-se a fazer ou responder a algumas perguntas por intermédio do mediador. Normalmente, não há tolerância a longos períodos de silêncio ou expressão de sentimentos. Com uma orientação diretiva, o facilitador se expressa na maior parte do processo, perguntando de forma contínua à vítima e ao ofensor, havendo pouco diálogo entre as partes.

Já a Mediação Penal além dos debates acerca da reparação civil, restabelece o diálogo entre ofendido e ofensor, sendo mais sensível à vítima. $\mathrm{O}$ enfoque deste processo

\footnotetext{
${ }^{15}$ Obras doutrinárias:

V. UMBREIT, Mark S. The Handbook of Victim Offender Mediation: An Essential Guide to Practice and Research, São Francisco, CA: Ed. Jossey Bass, 2001;

ASHWORTH, Andrew, Responsabilities, Rights and Restorative Justice, British Journal of Criminology 42, 2002; MORRIS, Allison, Critiquing the Critics, British Journal of Criminology n ${ }^{\circ}$ 42, 2002; MOORE, Christopher; $O$ Processo de Mediação. Porto Alegre: Ed. Artes Médicas, 1998 entre outros.
} 
é de proporcionar uma oportunidade aos envolvidos no conflito de se comunicarem diretamente, permitindo que as vítimas se expressem acerca do integral impacto do crime nas suas vidas e ouvirem respostas às perguntas que eventualmente tenham. Este direcionamento, busca estimular os ofensores a perceberem o real impacto humano de seu comportamento, a assumirem a infração cometida, a repararem os danos e terem também a possibilidade de expor em suas perspectivas as circunstâncias e conseqüências do crime.

Apesar da Mediação Vítima -Ofensor estar mais voltada ao ofendido, o ofensor também tem dentro deste processo, a oportunidade de relatar o crime para a vítima sob o seu olhar; não no intuito de mensurar, dividir ou culpar mais ou menos uma parte ou outra, mas sim, de poder compartilhar com a vítima a sua visão das circunstâncias e o modo como aquele crime lhe atingiu.

Nesta forma de Mediação, antes da primeira sessão conjunta são realizados encontros prévios com cada parte. Essas conversas prévias servem para dar ênfase ao debate de como o crime afetou as partes, bem como na identificação de interesses, necessidades e outros pontos preparatórios à sessão (conjunta) de mediação; em regra, esses encontros duram cerca de uma hora. Além disso, é dado constantemente às vítimas o poder de optar pelo lugar em que gostariam de se encontrar com o ofensor e, também, se gostariam da presença de outras pessoas na sessão de mediação.

Os mediadores ou facilitadores, neste caso, são membros voluntários da comunidade, monitorados ou não por agentes públicos. Caracterizam-se por possuírem um estilo não diretivo e por fazerem com que as partes tenham uma posição mais ativa dentro do processo, se expressando com mais freqüência que o próprio mediador. Há acentuada tolerância ao silêncio, à expressão de sentimentos e debates acerca do real impacto do crime, do uso de modelos humanísticos ou transformadores, dando sempre ênfase ao diálogo direto entre as partes envolvidas e o mediador, evitando-se excessos. 
Outra diferenciação exposta entre a mediação e a Mediação Penal é a ausência da necessidade de uma relação prévia entre as partes. Normalmente, o que ocorre em processos de mediação é a sua aplicação aos conflitos que envolvam partes que tenham algum tipo de relação permanente, pois permite o restabelecimento dos vínculos desses indivíduos que conviverão no futuro; a exemplo têm-se os casos de família, trabalho e membros da mesma comunidade. No entanto, quando se trata de uma infração penal, as partes não necessariamente apresentam algum vínculo.

Além disso, o processo de Mediação Penal possui etapas a serem seguidas, como será visto a seguir, diferentemente do que ocorre com outras formas de mediação, em que não é possível verificá-las; "o que é visto é apenas um caminhar altamente variável conforme o envolvimento pessoal das partes no processo, não se podendo estipular, com precisão, o desenrolar do processo de um determinado modo" (AZEVEDO, 2009, p83)

Insta salientar mais uma vez, que o processo de Mediação Penal não pretende substituir o sistema criminal atual, seu propósito é de apenas complementar o aparato tradicional, preenchendo suas lacunas falhas, de modo a obter melhores resultados em resposta às infrações penais.

\subsection{2 - ETAPAS DO PROCESSO DE MEDIAÇÃO PENAL}

Em se tratando das etapas do procedimento da Mediação Penal, o professor Ulf Nordenstahl apresenta cinco. (p-83, 2005). A primeira seria a indicação através de uma triagem em quais casos haveria a possibilidade de sua aplicação, sendo encaminhadas somente as disputas que efetivamente tenham, através deste processo, um potencial de resolutividade. (AZEVEDO, 2007, p-30)

Após a seleção dos casos para a Mediação Penal, o responsável por esta triagem deverá realizar a pré-mediação. Neste momento, ocorre a leitura do caso pela equipe 
mediadora, tornando-se conhecida a denúncia e as partes que poderão ou não participar do processo. Diante disso, é feito o convite à vítima e ao ofensor, esclarecendo que é de livre escolha sua participação, bem como o acompanhamento por advogado. (NORDENSTAHL, 2005, pp-83-88).

Com a aceitação dos envolvidos em integrar o processo de mediação, serão marcados encontros conjuntos, com os ofensores e as vítimas, sendo feito o discurso de abertura. Neste, serão esclarecidas todos os procedimentos da Mediação Penal, as vantagens e desvantagens da busca por uma autocomposição, a identificação de interesses, exigências e outros pontos preparatórios à sessão conjunta de mediação. Caso sinta necessidade, o mediador poderá indicar a realização de reuniões privadas com as partes.

No entanto, André Gomma e Mark Umbreit afirmam que deverão ser realizadas primeiramente reuniões individuais com as vítimas e os ofensores, precedendo a primeira sessão conjunta. Durante esses encontros privados, Gomma diz haver necessidade de se dar enfoque às conversas que identifiquem os interesses e necessidades das partes, de saber de qual maneira o crime as afetou e de se realizar a seleção de pontos prévios para a sessão conjunta. (AZEVEDO, 2007, p-29) e (UMBREIT, 2001).

Dentre os procedimentos fundamentais concernentes à Mediação Penal, a confidencialidade está presente, ou seja, têm-se a certeza, por exemplo, de que qualquer assunção de responsabilidade pelo fato não será revelada. Ou mesmo, nos casos em que for ocorrer julgamento processual, não haverá a transmissão de informações obtidas durante a mediação (ex: comportamento das partes) ao juiz competente para julgar a lide penal, salvo se houver autorização do ofensor. (AZEVEDO, 2007, p-30).

Prosseguindo com as etapas definidas pelo professor Ulf, o segundo plano seria a exploração do problema pelo mediador que, através de suas técnicas, faz perguntas às partes, reconstruindo o discurso relatado pelos envolvidos durante o processo. A finalidade desta reelaboração é a criação pelo mediador de um resumo a ser lido ao 
ofensor e ao ofendido, redefinindo o problema de acordo com as conclusões obtidas. Logo em seguida, elabora-se uma agenda de trabalho, estabelecendo os objetivos da vítima e seu ofensor, tais como: os temas que serão tratados, a distribuição do tempo para cada um, como se dará a negociação, quem participará do processo etc. (2005, pp-88-92).

A terceira fase consistirá na elaboração de propostas pelas partes a partir do que considerem como possibilidades de solução do problema, ou seja, suas atuações como protagonistas na resolução do conflito. O mediador, seguindo as regras e procedimentos da Mediação Penal, também pode elaborar propostas durante as reuniões, mas sempre mantendo a imparcialidade. (NORDENSTAHL, 2005, pp-92-94).

A quarta fase ocorre somente quando as partes, após a análise de todas as propostas, vêem a possibilidade de autocompor um resultado para o conflito. Assim, são traçados os pontos fundamentais do acordo, que deve ser de concordância dos envolvidos.

Segundo Mark Umbreit, apesar da maioria dos casos de Mediação Penal resultar em acordo, este não é o seu objetivo principal, mas sim os benefícios e oportunidades que este processo trará às partes em relação ao conflito que as envolve. A restauração do diálogo é de extrema valia, pois há uma grande necessidade de obtenção de informações e extravasamento das emoções da vítima, essencial para sua recuperação. Quanto ao ofensor, o desenvolvimento de uma empatia pela vítima pode levar a uma diminuição da reincidência do crime no futuro. (UMBREIT, Mark, 2007, p-77)

Salienta-se também, que a realização do acordo não consistirá em um reconhecimento de culpa, pois:

"reconhecer o fato e eventualmente assumir uma responsabilidade por suas conseqüências, não equivale a assumir a culpa jurídico-penal, até porque o ofensor pode aceitar que o fato ocorreu, entender que deve reparar suas conseqüências e preservar o direito de alegar causas excludentes ou de justificação para sua conduta, o que só poderá ocorrer em juízo, já que o mediador não desenvolve qualquer atividade probatória e, no mais, as discussões são confidenciais" (AZEVEDO, 2007, pp-158-189). 
A quinta fase do processo de mediação penal na concepção de Ulf é a chamada "seguimento e controle", ou seja, deve haver um monitoramento da manutenção de tudo que fora trabalhado e acordado durante o processo de mediação. (NORDENSTAHL, pp97-98).

Segundo Renato Campos Pinto De Vitto, é possível haver uma análise judicial do acordo firmado entre as partes, condicionando à aprovação de sua homologação à autoridade judicial responsável, que conseqüentemente, também influenciará na definição da repreensão concreta daquele caso (2005, p-41-52).

Além disso, conforme Renato Sócrates Gomes Pinto, o processo de mediação não revoga o princípio da inafastabilidade da jurisdição, podendo todas as partes legitimadas ${ }^{16}$ questionar o acordo restaurativo em juízo. (2005, p-28)

Ressalta-se, novamente, que, na ausência de um acordo, todas as informações obtidas no processo de mediação não poderão ser utilizadas, inclusive para o agravamento da sanção imposta ao ofensor pelo sistema penal tradicional. Como visto anteriormente, são sempre resguardadas sigilosamente todas as conversas realizadas durante o processo, com base no princípio da confidencialidade. (DE VITTO, 2005, pp41-52).

Em casos de não obtenção de êxito na Mediação Penal, não há possibilidades deste procedimento influenciar de alguma maneira a pena a ser aplicada pelo juiz, com a volta do caso para o sistema tradicional penal. O Magistrado Joaquim Domingos concorda com esta afirmativa, tendo em vista que a mediação é cercada de sigilo, ou seja, as informações obtidas não são reveladas. Portanto, fora da esfera que se deu a mediação, não é sabido, por exemplo, quem se recusou a continuar ou se o réu estava sendo intolerante. Isto se dá justamente para não influenciar o juízo de alguma simpatia ou antipatia. O que se faz no JECRIM, quando uma mediação não teve sucesso, é apenas

\footnotetext{
${ }^{16}$ Partes legitimadas: a vítima, o infrator - através de advogados -, assim como o Ministério Público, de ofício ou a requerimento do interessado.
} 
informar que aquele processo de mediação não pôde avançar, devendo ser retomado o sistema tradicional, nos mesmos termos como fora encaminhado à mediação; qualquer outro motivo pelo qual a mediação não pôde avançar não é informado. (Anexo VII)

\subsection{3 - EFEITOS DO PROCESSO DE MEDIAÇÃO PENAL}

Em conformidade com o autor Breno Zaban Carneiro, a mediação penal apresenta efeitos, quais sejam: 1) a satisfação dos envolvidos no processo; 2) a restituição do prejuízo causado pelo ofensor à vítima; 3) a menor utilização do sistema de justiça convencional; 4) a diminuição da reincidência criminal; 5) um impacto psicológico positivo sobre a vítima e 6) a economia de gastos nos casos de ofensas penais. (2007, pp224-225). A seguir, serão detalhados os efeitos supracitados.

1) Foi constatada em diversos estudos sobre a aplicação do processo de mediação uma grande satisfação das partes. As vítimas e ofensores afirmavam terem tido um processo justo e uma boa condução do caso pelo sistema. (CARNEIRO, 2007, pp-224-225).

"Todos esses estudos descobriram que a ampla maioria das vítimas e dos ofensores beneficia-se do processo, encontrando-se com o outro, conversando a respeito do crime e seu impacto sobre todos os envolvidos e elaborando um plano para reposição das perdas. Se os programas de mediação vítima-ofensor não são a solução para todas as formas de crime e delinqüência, eles oferecem, ainda assim, vários benefícios para o sistema de justiça." (UMBREIT, 2007, p-78).

2) Também foram observados altos índices de acordos de reparação, embora a restituição material não seja um elemento essencial da mediação. Além disso, há maior probabilidade de efetiva reparação nos casos mediados se comparados às ordens judiciais para pagamento de restituição. (CARNEIRO, 2007, pp-224-225).

3) Quanto à redução da utilização do sistema convencional de justiça, apesar de não ser também objetivo da Mediação Penal foi constatada uma diminuição do número de julgamentos realizados. (CARNEIRO, 2007, pp-224-225). 
4) A contenção da reincidência criminal foi vista nos estudos: os ofensores que participam da Mediação Penal, em geral, são menos propensos a cometer novos crimes, quando comparados àqueles que não participaram desse processo. (CARNEIRO, 2007, pp-224-225).

5) Há um impacto psicológico positivo sobre a vítima: os índices apontam para uma sensível redução do medo que as vítimas têm de se tornarem novamente alvos dos mesmos ofensores. (CARNEIRO, 2007, pp-224-225).

6) A observância da redução dos gastos nos casos penais é um dado ainda pouco consistente, podendo variar sensivelmente dependendo do custo e do tempo dedicado a cada processo e o número de mediações realizadas. (CARNEIRO, 2007, pp-224-225).

O estudo realizado por Mark Umbreit, publicado em seu artigo "Justiça Restaurativa por meio da mediação vítima-ofensor: uma avaliação a partir de várias experiências locais", estabeleceu os efeitos gerais do processo de mediação penal sobre a vítima e seu ofensor e será explicitado a seguir para um aprofundamento maior do assunto.

O processo de Mediação Penal proporciona para as vítimas, um ganho de confiança pessoal e um sentimento de paz ao serem finalmente ouvidas: deixam de ter medo e raiva, não mais se preocupando com seu ofensor. O infrator deixa de exercer um controle sobre o ofendido, não sendo mais visto como um "monstro" e eliminando a vontade que muitas tinham de se suicidar.

No caso dos ofensores, a Mediação Penal proporciona uma descoberta de emoções e sentimentos de empatia, aumentando o conhecimento pessoal, e de uma melhor visão das consequiências do impacto que seus atos causaram. Os infratores passam a se sentir bem por terem tentado o processo e conseguem olhar o mundo fora da prisão, ao invés de pensarem somente na vida dentro da instituição, alcançando a paz de espírito ao saberem que uma vítima foi ajudada. (UMBREIT, 2007, p-88). 


\section{3 - A INCIDÊNCIA DA MEDIAÇÃO PENAL NA ESFERA PROCESSUAL}

A aplicação da Mediação Penal pode ser vista em diversos países com resultados muito positivos inclusive, quanto ao contentamento das vítimas e seus ofensores. $\mathrm{O}$ autor Mark Umbreit exemplifica esse dado: Estados Unidos da América com 291 programas; Inglaterra com 20 programas; Canadá com 26 programas; Alemanha com 293 programas; Austrália com 05 programas; Finlândia com 130 programas; e Áustria e Nova Zelândia é possível encontrar inúmeros programas. (UMBREIT, 1998).

Com relação à satisfação dos participantes nos programas supracitados nota-se um alto índice de sucesso, como pode ser visto a seguir: 1) da vítima com a indicação do caso para mediação: Estados Unidos tiveram 79\%, Canadá teve 78\% e Inglaterra teve 62\%. 2) do ofensor com a indicação do caso para mediação: Estados Unidos tiveram 87\%, Canadá teve $74 \%$ e Inglaterra teve $79 \%$. 3) da vítima com o resultado da mediação: Estados Unidos tiveram 90\%, Canadá teve $89 \%$ e Inglaterra teve $84 \%$; 4) do ofensor com o resultado da mediação: Estados Unidos tiveram 91\%, Canadá teve 91\% e Inglaterra teve $100 \%$; 5) quanto ao temor da vítima em ser revitimada pelo ofensor: Estados Unidos tiveram 10\% (56\% menos que o índice das vítimas que não participaram desse tipo de processo), Canadá teve 11\% (45\% menos que o índice das vítimas que não participaram desse tipo de processo), Inglaterra teve16\% ( $37 \%$ menos que o índice das vítimas que não participaram desse tipo de processo); 6) quanto à percepção de justiça pela vítima com a indicação do caso para mediação: Estados Unidos tiveram 83\%, Canadá teve 89\% e Inglaterra teve 59\%; 7) quanto à percepção da justiça pelo ofensor com a indicação do caso para mediação: Estados Unidos tiveram $89 \%$, Canadá teve $80 \%$ e Inglaterra teve 89\%. (UMBREIT, Mark e ROBERTS, A.W.,1998).

No caso do Brasil, não há legislação específica regulando a aplicação do processo de Mediação Penal. No entanto, existem dispositivos que garantem o uso dessa alternativa de solução de controvérsias, de forma a complementar o sistema judicial em 
vigor, tais como a Constituição da República Federal do Brasil em seu Artigo 98, I e os institutos da Lei ${ }^{\circ}$ 9.099/95.

O Artigo 98 da Constituição da República Federativa do Brasil prevê:

“A União, no Distrito Federal e nos Territórios, e os Estados criarão: I. Juizados especiais, providos por juizes togados, ou togados e leigos, competentes para a conciliação, o julgamento e a execução de causas cíveis de menor complexidade e infrações penais de menor potencial ofensivo, mediante os procedimentos oral e sumaríssimo, permitidos,nas hipóteses previstas em lei, a transação e o julgamento de recursos por turmas de juízes de primeiro grau;"

A Lei $n^{\circ}$ 9.099/95, que regula os Juizados Especiais Cíveis e Criminais admite o uso do acordo civil (artigo 74 e 74), da transação penal (artigo 76) e da suspensão condicional do processo (artigo 89) nos crimes de menor potencial ofensivo.

Lei $n^{\circ}$ 9.099/95:

Artigo: 72. "Na audiência preliminar, presente o representante do Ministério Público, o autor do fato e a vítima e, se possível, o responsável civil, acompanhados por seus advogados, o Juiz esclarecerá sobre a possibilidade da composição dos danos e da aceitação da proposta de aplicação imediata de pena não privativa de liberdade."

Artigo: 74. "A composição dos danos civis será reduzida a escrito e, homologada pelo Juiz mediante sentença irrecorrível, terá eficácia de título a ser executado no juízo civil competente."

Parágrafo único. "Tratando-se de ação penal de iniciativa privada ou de ação penal pública condicionada à representação, o acordo homologado acarreta a renúncia ao direito de queixa ou representação."

O emprego da Mediação Penal através desses dispositivos dá-se pelo entendimento strito sensu e lato sensu do instituto da conciliação previsto pelos dispositivos acima citados. Sendo assim, a Mediação Penal é abrangida pela forma latu sensu da conciliação, havendo, portanto, caminhos quanto à sua aplicação dentro do ordenamento jurídico brasileiro. Cabe lembrar que embora tenham natureza jurídica 
semelhante, tanto a transação penal quanto a conciliação não se incluem nos conceitos de justiça restaurativa e mediação.

Sendo assim, há a possibilidade de recepção no ordenamento jurídico brasileiro dessas medidas, permitindo a instauração de projetos, tais como nas cidades de Porto Alegre/RS, São Caetano do Sul/ SP, Distrito Federal (SICA, 2007, p-225) e Rio de Janeiro/RJ.

Mesmo que ainda em fase embrionária, foram constatadas pelo autor Leonardo Sica, algumas conclusões com relação à aplicação dos três primeiros projetos. A primeira delas, foi a de que os acordos realizados devem ser amparados por uma legislação da justiça penal e de que a mediação é o meio mais aconselhável para vencer as incompatibilidades específicas da justiça restaurativa com o sistema penal brasileiro. (Ibid.)

Foi percebido também, pouco êxito quanto à indicação para a justiça restaurativa de crimes de bagatela, de casos pouco esclarecidos e/ou de duvidosa adequação típica, pois podem gerar graves ilegalidades, desvios de função e a expansão disfarçada do contole punitivo. Como exemplo do exposto, têm-se no projeto de São Caetando do Sul/SP, uma submissão de menores de idade envolvidos em fatos atípicos, à conferências restaurativas supervisionadas pela justiça comum, com objetivos meramente disciplinadores. (Ibid., p-226).

Concluiu-se também que a justiça restaurativa não pode se sobrepor à justiça tradicional por conta da possibilidade de bis in idem ${ }^{17}$, de revitimização e por serem institutos diferentes. No projeto de Porto Alegre/RS, o exemplo quanto a conclusão mencionada dá-se pela instauração de medidas restaurativas após a sentença pela vara de execução de medidas sócio-educativas, o qua acarreta a acumulação destas com a

\footnotetext{
${ }^{17}$ Bis in idem dentro do contexto analisado corresponde à dupla, ou múltipla punição do mesmo indivíduo. Sendo certo, que o princípio válido no ordenamento jurídico brasileiro é o do non bis in idem, ou seja, a proibição dessa dupla ou múltipla punição.
} 
sentença. Além disso, a aplicação das primeiras ocorre em uma distância temporal do fato o que prejudica sensivelmente o diálogo.

No Rio de Janeiro, os programas em questão referem-se à aplicação da mediação penal no IX e XVI Juizados Especiais Criminais (correspondem respectivamente aos Juizados Barra da Tijuca e Jacarepaguá) e vêm demonstrando resultados bastante positivos quanto aos índices de acordos nos casos encaminhados a esse processo.

Em entrevista realizada com os Juizes do IX e XVI Juizados Especiais Criminais (ou JECRIM) da Comarca da Capital do Rio de Janeiro, puderam ser colhidas informações muito importantes a respeito do trabalho de mediação aplicado nesses Juizados.

Segundo o Dr. Juiz de Direito Arthur Narciso, o XVI Juizado Especial Criminal vem obtendo números bastante satisfatórios com relação à aplicação do processo de mediação. De todos os procedimentos realizados, o índice de acordo foi de 70\%, ou seja, um número bastante elevado.

Conforme o Dr. Juiz de Direito Joaquim Domingos, no IX Juizado Especial Criminal, são realizados dois tipos de mediação: uma realmente penal, ou seja, que influencia em questões de pena, e outra de natureza civil dentro de um Juizado Criminal. A Lei $n{ }^{\circ}$ 9099/95 autoriza essa forma de trabalho, ou seja, a formação de um acordo civil com efeitos penais, afastando totalmente a jurisdição penal. Sendo assim, o que é feito na verdade dentro do IX JECRIM é uma mediação civil que implica na eliminação também o processo penal e não diretamente uma Mediação Penal clássica como é descrita nos livros.

A exemplo do exposto acima, o Dr. Joaquim Domingos ilustra alguns casos de uso da mediação civil dentro de uma área penal: na reparação de danos em um acidente de trânsito, em conflitos de vizinhança e familiares (muitas vezes esses dois últimos se confundem). A mediação realizada nos casos citados é de natureza civil; no entanto seus 
efeitos são penais, extinguindo a punibilidade, terminando o processo e evitando a instauração de outros na Vara Cível. No $1^{\circ}$ caso, são acordados apenas os danos entre o autor e vítima; nos $2^{\circ}$ e $3^{\circ}$ casos, além desta reparação, por se tratar de uma relação continuada, o acordo dá-se pela necessidade de se estabelecer novas formas de convivência entre as partes e regras para o futuro.

Nos fatos narrados, não há a aplicação de uma série de características que a Mediação Penal demanda, esse instituto só seria utilizado em sua forma puramente clássica, se fossem respeitados determinadas características, tais como: 1) quanto à vítima: a realização de um processo em que esta se sentisse satisfeita com o cumprimento de uma determinada pena pelo seu ofensor, fazendo-o enxergar os malefícios causados com o seu ato. Exemplo: a realização de trabalhos voluntários em um determinado local e em um delimitado período. 2) quanto ao ofensor: seria necessária uma assunção de culpa de sua parte:"Cometi o fato criminoso e por isso vou reparar o dano causado prestando serviços à comunidade.', bem como, ser dada ao ofensor a oportunidade de se explicar, relatando os seus sentimentos e a sua maneira de ver o fato ocorrido.

Nos dois Juizados Especiais Criminais analisados, por ser o processo de mediação um recurso muito escasso, é dada a preferência a casos de relações continuadas, familiares, vizinhança, crimes de desobediência, ou até relações societárias (muito freqüentes no IX Juizado Especial Criminal).

O Dr. Joaquim Domingos cita também outros benefícios processuais da mediação, quais sejam: a maior eficácia de um acordo obtido se comparado a uma sentença e a extinção de outros processos que se correlacionam. Isto é, quando analisada a aplicação da mediação em termos de um único processo, muitas vezes pode aparentar ser um processo duradouro. Contudo, ao se verificar os efeitos provocados, uma mediação com êxito, poderá resolver e/ou evitar muitos outros processos que se interligam. Por exemplo, ao se pensar em dividir a duração de três meses de um processo de mediação bem sucedido, por três outros processos existentes entre as partes, o dado obtido é de um 
mês para a resolução de cada um, o que corresponde a um período muito curto dentro do sistema judiciário.

\section{1 - A MEDIAÇÃO PENAL NOS CASOS DE AÇÕES PENAIS PÚBLICAS E PRIVADAS}

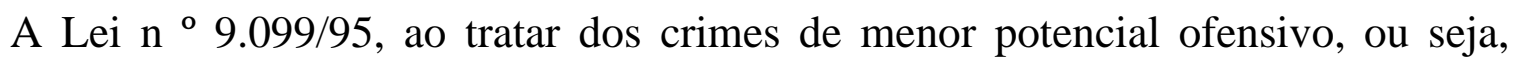
daqueles em que a pena máxima não ultrapasse 2 (dois) anos, abriu um caminho para a implementação da mediação no processo.

Nas Ações Penais Privadas $^{18}$ e Públicas Condicionadas à Representação ${ }^{19}$ previstas na Lei ${ }^{\circ}$ 9.099/95, a mediação se torna uma das opções a serem oferecida às partes, com o intuito de oportunizar a autocomposição do dano, o que pode resultar na renúncia à queixa ou representação antes de formalizadas. (SICA, 2007, p-226).

Cabe ressaltar que a Mediação não se confunde em nada com a conciliação, conforme o caso acima exposto, apesar do resultado processual ser o mesmo quando a aplicabilidade desses dois institutos resultar em um acordo. No entanto, a mediação, além de apresentar este resultado, produz inúmeros outros efeitos positivos, como já mencionados anteriormente neste trabalho.

A reparação do dano neste contexto, materializada por um acordo realizado entre as partes, possibilita a implementação da mediação. Se bem sucedida, ocasiona nas Ações

\footnotetext{
${ }^{18}$ Ação Penal Privada: o direito subjetivo de promover a ação é privativo do ofendido. Contudo, a execução penal permanece sendo de exclusividade do Estado. Há casos em que, diante da inércia do Ministério Público quanto ao oferecimento da denúncia, a ação penal privada funciona como subsidiária da pública, podendo o ofendido apresentar queixa, substituindo a denúncia do Ministério Público que deveria ter atuado para a sua proposição. (BITENCOURT, pp- 749-752)

19 Ação Penal Pública Condicionada à Representação: o Ministério Público é o titular da Ação Penal Pública (Artigo 129, I, Constituição da Republica Federativa Brasileira), porém, nesses casos, a propositura da ação dependerá da representação do ofendido ou de quem tenha qualidade para representá-lo ou, ainda, de requisição do Ministro da Justiça.

Os crimes em que a ação pública ficará condicionada à requisição do Ministro da Justiça são os praticados por estrangeiros contra brasileiros fora do Brasil (artigo $7^{\circ}$, parágrafo $3^{\circ}$ do Código Penal) e aqueles cometidos contra a honra do presidente da República ou chefe de governo estrangeiro (artigo 145, parágrafo único do Código Penal). (Ibid.)
} 
Penais Públicas Condicionadas-antes da representação- e nas Ações Penais Privadas, conforme dito anteriormente, a renúncia ao direito de queixa ou representação, prevista no artigo 74, parágrafo único da Lei ${ }^{\circ} 9.099$ :

Artigo 74, parágrafo único da Lei n ${ }^{\circ} 9.099$ "Tratando-se de ação penal de iniciativa privada ou de ação penal pública condicionada à representação, o acordo homologado acarreta a renúncia ao direito de queixa ou representação.',

\subsection{1 - A MEDIAÇÃO PENAL NO QUE TANGE À SUSPENSÃO CONDICIONAL DO PROCESSO}

O artigo 89 da Lei $n^{0}$ 9.099/95 prevê a suspensão condicional do processo, abrindo-se mais uma vez um caminho direto para a implementação da mediação nos casos de Ação Penal Pública Condicionada e Incondicionada ${ }^{20}$, pois possibilita uma solução consensual em crimes cuja pena mínima cominada for igual ou inferior a um ano, desde de que tenha havido a reparação do dano por parte do ofendido.

"Ao receber a denúncia, o juiz, ao invés de designar o interrogatório, delegaria o caso para ofício de mediação, que se incumbiria de estabelecer o contato com as partes, informá-las da possibilidade de negociar uma solução, realizar as sessões de mediação e conduzir o diálogo que pode ou não resultar na reparação do dano, suficiente para a justiça penal homologar o acordo e decretar a extinção da punibilidade." (SICA, 2007, p-229)

O artigo 89, caput, da Lei no 9.099/95 prevê:

"Artigo. 89. Nos crimes em que a pena mínima cominada for igual ou inferior a um ano, abrangidas ou não por esta Lei, o Ministério Público, ao oferecer a denúncia, poderá propor a suspensão do processo, por dois a quatro anos, desde que o acusado não esteja sendo processado ou não tenha sido condenado por outro crime, presentes os demais requisitos que autorizariam a suspensão condicional da pena (art. 77 do Código Penal)."

\footnotetext{
${ }^{20} \mathrm{O}$ instituto da suspensão condicional do processo só é cabível para os casos de Ação penal Pública Condicionada ou Incondicionada, não sendo estendido às Ações Privadas, devido à falta de previsão legal para esta última. $\mathrm{O}$ artigo 89 da Lei $\mathrm{n}^{\circ}$ 9.099/95, ao determinar que “ o Ministério Público, ao oferecer a denúncia, poderá propor a suspensão do processo", reporta-se aos casos de início das Ação Penais Públicas, tendo em vista que o começo das Ações Penais Privadas dá-se por queixa-crime pelo próprio ofendido, através de seu advogado, ou seja, não se configurando o momento previsto por este dispositivo legal. (BITENCOURT, 2004, pp-660-662).
} 
Com base na letra da lei, constata-se que a suspensão do processo está condicionada a pressupostos e requisitos, como, por exemplo, à pessoa do réu, ao fato, a suas circunstâncias e a uma pena mínima cominada igual ou inferior a um ano.

Esse instituto apresenta um rol abrangente quanto aos crimes que é capaz de englobar -bem como a possibilidade de aplicação do processo de mediação- por exemplo: homicídio culposo, aborto consentido, lesões corporais graves -no caso de debilidade permanente e perigo de vida-, perigo de contágio de moléstia grave, abandono de incapaz, omissão de socorro, rixa qualificada -com morte-, calúnia difamação, injúria quando forem públicas condicionadas-, furto simples, dano -simples e qualificada-, estelionato, falsidade ideológica, corrupção -ativa e passiva-, prevaricação etc. (BITENCOURT, 2004, p-658).

Faz-se necessário também que o acusado não esteja sendo processado, ou seja, o mero fato de o individuo estar respondendo a processo por outro crime constitui um impedimento para a suspensão do processo. A condenação por outro crime é outro obstáculo ao emprego deste instituto; tendo sido o individuo condenado por outra infração penal definitivamente e de forma irrecorrível, não será contemplado pela suspensão condicional do processo.

Além desses requisitos analisados, são demandados também aqueles previstos no artigo 77 do Código Penal, quais sejam: 1) natureza e gradação da pena: apenas nos casos em que incorra pena privativa de liberdade, pode ocorrer a suspensão condicional do processo; em se tratando das penas restritivas de direitos e de multa (artigo 80 do Código Penal), a suspensão analisada não é aplicada; 2) inaplicabilidade de penas restritivas de direito; 3) falta de certeza quanto à reincidência do crime pelo ofensor: alguns elementos possibilitam uma previsão da conduta futura do condenado, que, se positiva, indicam pouca possibilidade de reincidência e servirão de base para a suspensão ou não do processo, tais como: os elementos definidores da medida da pena, culpabilidade, antecedentes, conduta social, personalidade do réu, motivos e circunstâncias do crime. 
Após a análise quanto ao cabimento do instituto da suspensão condicional do processo para determinado caso e a aceitação de sua aplicação pelo acusado e seu defensor, o artigo 89, em seu parágrafo $1^{\circ}$, apresenta as condições impostas para a sua concessão:

Artigo 89, parágrafo $1^{\circ}$ da Lei ${ }^{\circ}{ }^{9}$.099/95:

"Aceita a proposta pelo acusado e seu defensor, na presença do juiz, este, recebendo a denúncia, poderá suspender o processo, submetendo o acusado a período de prova, sob as seguintes condições:

I- $\quad$ reparação do dano, salvo impossibilidade de fazê-lo;

II- $\quad$ proibição de freqüentar determinados lugares;

III- $\quad$ proibição de ausentar-se da comarca onde reside, sem autorização do juiz;

IV- comparecimento pessoal e obrigatório a juízo, mensalmente, para informar e justificar suas atividades.”

Salienta-se que a implementação da mediação dentro da suspensão condicional do processo tem, na reparação do dano, a condição para o acordo entre as partes. $\mathrm{O}$ cumprimento deste provoca a extinção da punibilidade.

De acordo com o autor Cezar Bitencourt, a reparação do dano prevista no inciso I, do parágrafo $1^{\circ}$, do referido artigo é uma das grandes preocupações da Lei ${ }^{\circ}{ }^{\circ}$ 9.099/95, pois se apresenta como uma obrigação natural decorrente da prática da infração penal. O acusado, responsável pela reparação civil, terá como primeira condição para a obtenção da suspensão condicional do processo a obrigação de reparar o dano, salvo efetiva impossibilidade de fazê-lo.

Cabe destacar que a suspensão efetiva do processo fica condicionada ao resultado positivo do período de provas, ou seja, o cumprimento real das condições que foram 
estabelecidas consensualmente no recebimento da denúncia. Se bem sucedida esta condição, ocasiona a extinção da punibilidade.

Leonardo Sica ressalta, ainda, que o uso da Mediação Penal dentro da suspensão condicional do processo, impossibilita a aplicação pelo juiz das demais condições deste instituto previstas nos incisos II, III e IV, do artigo 89, parágrafo $1^{\circ}$, da Lei $n{ }^{\circ} 9.099 / 95$ : II- a proibição de freqüentar determinados lugares; III- proibição de ausentar-se da comarca onde reside, sem autorização do juiz e, IV-o comparecimento pessoal e obrigatório a juízo, mensalmente, para informar e justificar suas atividades. Salvo se as partes acordarem livremente alguma destas, como forma de reparação simbólica e de recomposição da paz jurídica. (2007, p-229)

Ainda em conformidade com o supracitado autor e com uma decisão do Tribunal Regional Federal da 3ª Região (HC 2003.03.0073280-0, julgado em 15/03/2004) presente em sua obra, apesar desse entendimento não ter sido acolhido pela jurisprudência, outra possibilidade de aplicação da mediação, correlacionada à suspensão condicional do processo, seria no caso de crimes cuja pena mínima fosse igual ou inferior a dois anos, isto é, não apenas para os crimes em sua forma simples -crimes em que a pena mínima cominada for igual ou inferior a um ano- mas também quando incidir sua forma qualificada. (SICA, 2007, pp-225-230)

A aplicação da suspensão condicional do processo no exemplo supracitado seria inviável pela redação do artigo 89 da Lei $\mathrm{n}^{\circ}$ 9.099/95; no entanto, conforme o entendimento mencionado acima, ao se utilizar uma maior abrangência do conceito de infração penal de menor potencial ofensivo, tal qual preceituado Lei $\mathrm{n}^{\circ} 10.259 / 01$, em conjunto com os princípios da isonomia e igualdade, haveria a possibilidade jurídica de aplicação da suspensão condicional do processo nos crimes em que a pena mínima fosse igual ou inferior a dois anos.

O citado julgado afirma que o entendimento majoritário contrário ao seu seria uma incongruência jurídica, além de ofender o princípio da isonomia. A visão do autor, 
assim como o da referida decisão, é de que este princípio, bem como o da igualdade, teriam feito com que a Lei $n^{\circ}$ 9.009/95 acolhesse a nova disposição da Lei $n^{\circ}$ 10.259/01, ou seja, abarcando também os crimes em que a pena mínima fosse igual ou inferior a dois anos, portanto, ampliando o rol da suspensão condicional do processo.

"Esse raciocínio lógico e isonômico contemplado na Lei $n^{\circ}$ 9.099/95 deve também nortear a aplicação da Lei $n^{\circ}$ 10.259/01, pois seria incongruente que alguém que não estivesse sendo processado e nem tivesse recebido condenação anterior, e que ainda contasse com os demais requisitos favoráveis do artigo 77 do Código Penal, o que levaria a que se fosse condenado viesse a ter uma pena máxima dentro do limite do conceito de infração de menor potencial ofensivo, e lhe fosse, mesmo assim, afastado do regime mais benéfico trazido pela norma [...]" (Ibid)

\section{2 - APLICAÇÃO DA MEDIAÇÃO PENAL EM CRIMES MAIS GRAVES}

Nos crimes mais graves, a mediação seria possível não no sentido de influenciar sobre o direito de ação, que pertence ao Estado, ou sobre a pena, cujos critérios de fixação se encontram previstos em lei, mas no sentido de permitir o diálogo entre as partes para preservar suas relações, ou restaurar o que fora desconstruído pelo crime, tanto para vítima quanto para seu ofensor.

O Doutor Joaquim Domingos também concorda com esta afirmação. Em conformidade com o magistrado, nos crimes mais graves, como no homicídio, estupro, roubo, há espaço para a aplicação da Mediação Penal -"aliás o seu uso é irrestrito"'-, mas nunca irá substituir ou influenciar a pena; a incidência destes procedimentos terá que vir depois de uma sentença condenatória, com o intuito de tratar da questão pontual de satisfação da vítima, daquela de cunho moral e até mesmo de contato e conversas entre ofendido e ofensor, no intuito de restaurar ou preservar as relações.

"Não há espaço processual para a aplicação da Mediação Penal durante o processo nesses casos supracitados. Dentro do processo ordinário e sumário o rito é muito concentrado, ocorre logo a A.I.J. (Audiência de Instrução e Julgamento). A incidência deste instituto durante o processo só poderia ocorrer com a suspensão condicional do processo, o que não é possível nesses crimes; assim, o momento cabivel se daria apenas depois da condenação. $O$ juiz inclusive poderia fixar na sentença, (dependendo da vontade das partes), a possibilidade de se mediar a indenização, mas em nada poderia influenciar a pena." (Entrevista Doutor Joaquim Anexo VII) 
A aplicação da mediação nesses casos visa principalmente oportunizar às vítimas de crimes violentos, dentro de um local seguro e estruturado, o encontro e o diálogo direto com seus ofensores, tornando mais palpável a restauração. Em alguns estados norte-americanos (Alasca, Califórnia, Nova Iorque, Minnesota e Texas), já existem programas com esse intuito, e os resultados são muito positivos quanto à satisfação de ambas as partes com a sua aplicação. No entanto, a autora Tatiana Sandy Tiago faz uma ressalva; além da voluntariedade de ambas as partes em realizar o procedimento, somente poderão participar aqueles ofensores que assumirem a culpa da infração cometida, estando arrependidos e querendo contribuir para a reparação do dano à vítima. (TIAGO, 2007)

Dentro da prisão, mas, na presença de um mediador, os pais de filhos assassinados e vítimas de crimes violentos podem se encontrar com os ofensores.

\begin{abstract}
"Muitas vítimas necessitam de respostas que apenas os ofensores podem fornecer, precisam expressar as conseqüencias causadas pelo ato criminoso ou simplesmente ouvir diretamente do ofensor que ele reconhece sua responsabilidade pelo dano causado e que se arrepende." (Ibid.)

"Vítimas e ofensores freqüentemente falam da sua participação em um diálogo

mediado como uma experiência poderosa e transformadora que os ajudou no seu processo de recuperação. Pais de crianças mortas expressaram seu sentimento de alívio após encontrarem o ofensor/presidiário e dividirem sua dor. Eles também puderam reconstruir o que aconteceu e o porquê. Uma mãe cujo filho foi assassinado declarou: "Eu apenas precisava deixá-lo ver a dor que ele causou na minha vida e descobrir por que ele puxou o gatilho." Um professor que foi atacado e quase morto comentou, após encontrar com o jovem criminoso na cadeia: "Ajudou-me a acabar com esse ordálio... fez muita diferença na minha vida, apesar desse tipo de encontro não ser para todo mundo." Um ofensor/presidiário que encontrou com a mãe do homem que havia matado declarou: "Foi bom poder trazer algum alivio para ela e expressar o meu remorso." Um médico na Califórnia cuja irmã foi morta por um motorista bêbado estava muito cético inicialmente quanto a encontrar com o ofensor. Após a sessão de mediação, ele declarou: "Eu não pude começar a me recuperar até que deixasse o ódio passar... após a sessão de mediação, eu senti um grande alívio...eu agora estava pronto a encontrar alegria na vida novamente." (UMBREIT, 2007, p-78).
\end{abstract}

Ressalta-se inclusive que parte da doutrina possui o entendimento de que a aplicação da Mediação Penal nesses tipos de casos, apesar de demandar mais cautela quanto ao seu uso, tem uma eficácia maior, sendo muito mais indicada pelo seu maior potencial restaurativo. (CARNEIRO, 2007) 


\section{3 - OUTRAS POSSIBILIDADES DE APLICAÇÃO DA MEDIAÇÃO PENAL NO PROCESSO E SUAS INFLUÊNCIAS}

Leonardo Sica, em sua obra, cita outras possibilidades de aplicação da Mediação Penal no processo. É o caso, por exemplo, do perdão judicial ${ }^{21}$, presente no artigo 120 do Código Penal, cuja previsão mesmo que de maneira limitada, vislumbra sua aplicação nos casos previstos nos artigos 121 , parágrafo $5^{\circ}$ e 129 , parágrafo $8^{\circ}$ do Código Penal, ou seja, restrito aos crimes de homicídio e lesão corporal culposos.

O referido autor também faz menção aos dispositivos presentes na Lei nº 8.137/90, a qual regulamenta os crimes contra a ordem tributária, em conjunto com a Lei $n^{\circ}$ 8.884/94 cujo espectro de abrangência inclui os crimes contra a ordem econômica, além do disposto pela Lei $\mathrm{n}^{\circ}$ 9.605/98 que tem como escopo a normatização dos crimes contra o meio ambiente; todas estas abrem possibilidades para a solução consensual. No caso dos crimes ambientais, apesar de não se ter uma vítima individual, há vários dispositivos que privilegiam a reparação do dano; portanto, havendo caminhos para a aplicação do processo de mediação àqueles interessados e legitimados a discutir uma solução para um determinado dano ambiental: Ministério Público, ofensor, órgãos ambientais e entidades não-governamentais (comunidade).

De acordo com o autor Renato Sócrates, nos crimes contra idosos, o processo restaurativo é possível por força do artigo 94, da Lei ${ }^{\circ}$ 10.741/03 (Estatuto do Idoso). Este artigo prevê a aplicação da Lei no 9.099/95 para crimes contra idosos cuja pena privativa de liberdade não ultrapasse 4 anos.

"Lei $n^{\circ}$ 10.741/03. Artigo 94. Aos crimes previstos nesta lei, cuja pena máxima privativa de liberdade não ultrapasse 4 anos, aplica-se o procedimento previsto na Lei 9.099/95 e, subsidiariamente, no que couber, as disposições do Código Penal e do Código de Processo Penal.',

\footnotetext{
${ }^{21}$ A lei através do perdão judicial possibilita ao juiz deixar de aplicar a pena diante da existência de determinadas circunstâncias expressamente determinadas, a exemplo: artigo 121, parágrafo $5^{\circ}$, artigo 129 , parágrafo $8^{\circ}$, artigo 140 , parágrafo $1^{\circ}$, incisos I e II, artigo 180 , parágrafo $5^{\circ}, 1^{\text {a }}$ parte, artigo 242, parágrafo único e artigo 249, parágrafo $2^{\circ}$, todos do Código Penal. (Bitencourt, 2004, pp-767-768).
} 
Ademais, o Estatuto da Criança e do Adolescente (Lei no 8.069/1990) também prevê e recomenda implicitamente o uso da Mediação Penal em vários de seus dispositivos, representando, de acordo com Leonardo Sica, uma esfera natural para o seu desenvolvimento, além de sua norma adaptar-se facilmente a este instituto e os efeitos quanto a esta aplicação serem bastante positivos, quais sejam: recuperar o sentido da medida socioeducativa -atualmente usada como punição- e evitar a estigmatização e segregação de crianças e adolescentes em conflito com a lei. (2007, p-226).

A medida socioeducativa é aplicada como penalização por prática de ato infracional cometido por adolescentes (Artigo 112 do Estatuto da Criança e do Adolescente, Lei $n^{\circ}$ 8.069/1990), o que, na visão do autor, contradiz a finalidade socioeducativa da medida.

$\mathrm{Na}$ entrevista realizada com o Doutor Joaquim Domingos, foi citada a possibilidade de realização de uma intervenção mediadora em crimes de drogas. Segundo o Magistrado, nesses crimes tem-se a Justiça Restaurativa muito mais presente a partir da Lei $n^{\circ} 11.343 / 2006$, pois a vontade do usuário deve ser respeitada, não pressupondo a sua abstinência para a realização do tratamento -para isso, seria necessário internar o usuário, o que tornaria menos provável a sua receptividade de adesão.

O Doutor Joaquim Domingos ilustrou esta aplicabilidade, relatando um caso concreto que tramitou perante o IX JECRIM. Tratou de uma intervenção mediadora de crime de drogas. No contexto de uma família composta por três irmãos que tinham recebido um apartamento de herança de sua mãe, localizado em bairro privilegiado do Rio de Janeiro, sendo certo que não havia a intenção de desocupação do bem por qualquer deles. No apartamento, viviam três irmãos: uma irmã, que tinha um filho ainda bebê, o irmão do meio, que fazia uso moderado de drogas, inclusive convidando pessoas para dentro do apartamento para consumir e o irmão menor, que tinha um problema mental associado ao uso de droga. Havia, portanto, o cometimento de um fato criminoso ameaças entre os irmãos, que, por vezes, resultavam em lesões corporais, além da posse 
de drogas para uso próprio-, que se agravava pelo risco permanente de a polícia invadir o local pela suspeita de tratar de um ponto de venda de drogas.

A Mediação Penal se deu nesse processo como minoração das repercussões dos fatos. A abordagem técnica aplicada a este procedimento foi apresentada no sentido de incrementar as chances de essa entidade familiar viver harmoniosamente dentro do apartamento que era de propriedade dos três; que tentassem se engajar em algum tipo de tratamento para superar o uso da droga e se comprometessem juntos, a não trazerem mais entorpecentes para dentro de casa. Essa Mediação Penal teve como resultado jurídico o arquivamento do processo pelo Ministério Público. O Dr. Joaquim Domingos tentou dar ao caso uma roupagem de mediação civil e esta já foi suficiente para a resolução do caso dentro da esfera penal, levando à redução dos danos e ao arquivamento do processo sem resposta penal. 


\section{IV - CONCLUSÃO}

A presente monografia procurou mostrar a ineficácia do sistema tradicional penal voltado ao encarceramento, com uma criminalidade e insegurança social cada vez mais acentuada, opressões e agressividades na resolução de conflitos.

Com o exercício da atual Justiça Retributiva, o que se vê é um desvio dos sentidos de prevenção e ressocialização das penas, provocando uma paz social com tensão. Isto é, devido aos regimes carcerários desumanos, ao sistema penal ultrapassado e as condições irrazoáveis de aplicação da pena, os resultados obtidos são de uma ressocialização secundária, que leva a um isolamento, desamparo e desintegração tanto do ofensor quanto da vítima.

Sendo assim, evidencia-se a necessidade de aplicação de mecanismos alternativos na área penal, de forma a complementar o sistema criminal atual e buscar novas soluções em conformidade com as normas jurídicas e princípios fundamentais.

A Justiça Restaurativa aparece como uma possibilidade neste contexto, superando a pouca efetividade e a forma obsoleta do aparato penal atual, pautando-se nos princípios da proporcionalidade e razoabilidade e dando maiores opções de resposta ao crime. A indicação deste modelo de justiça justifica-se devido à compreensão do crime em todos os seus aspectos e conseqüências, buscando a reconstrução das relações e diálogos entre vítimas e ofensores, para que, com a ajuda de um terceiro, possam realizar a autocomposição do conflito que as cercam.

Como já mencionado neste trabalho, tanto a vítima quanto o infrator, demandam uma participação dentro do processo, seja para reparar o trauma moral e os prejuízos emocionais com relação à vítima, seja através da assunção de culpa, reparação e restituição do erro cometido e prestação de serviços comunitários pelo infrator. 
A Mediação Penal foi a modalidade de Justiça Restaurativa estudada neste trabalho, com o objetivo de ser uma alternativa à resolução de conflitos, a fim de complementar o sistema penal tradicional. Através de suas características, procedimentos, formas e benefícios quanto à sua aplicação dentro ou fora do processo penal, pôde-se perceber sua eficácia e obtenção de um elevado índice de resultados positivos tanto para as partes envolvidas no conflito, como para a comunidade.

Dentre essas características supracitadas neste instituto, temos como exemplo: a assunção de culpa por parte do ofensor, uma maior assistência, compensação e participação da vítima no processo, o restabelecimento do diálogo entre as partes, dando ênfase à restauração da vítima, recuperação das perdas morais, patrimoniais e afetivas e também, dá-se à possibilidade de ambas as partes relatarem uma à outra a sua participação e os sentimentos que envolveram e envolvem o ato ocorrido.

Ou seja, permite aos envolvidos no conflito, voluntariamente, dentro de um ambiente seguro e na presença de um terceiro, construírem em conjunto um acordo que leve à resolução do conflito, à obtenção de respostas que na maioria das vezes as vítimas necessitam, bem como oportuniza o direito de fala e expressão de sentimentos, quanto à participação no conflito tanto da vítima como de seu ofensor.

Além destes resultados positivos, o uso deste método alternativo de resolução de conflitos proporciona outros efeitos bastante válidos, quais sejam: a diminuição da reincidência criminal e do uso do sistema penal tradicional -com a indicação à Mediação Penal de casos mais apropriados a aplicação deste processo-, uma elevação do índice de restituição do prejuízo causado e a realização de acordos mais eficazes.

Cabe salientar novamente, que apesar de todos os resultados processuais que a Mediação Penal pode trazer, foi possível concluir que o acordo obtido neste processo não é a sua finalidade em si, mas, sim, todas as oportunidades e benefícios trazidos às partes através deste instituto. 
Com relação à aplicação da Mediação Penal no ordenamento jurídico brasileiro, não há legislação específica que a regule no sistema penal tradicional; contudo, alguns dispositivos permitem o seu uso de maneira a complementá-lo, permitindo que determinados casos sejam encaminhados a este procedimento, por ser considerado o mais apropriado a resolução do conflito.

O artigo 98, inciso I, da Constituição da República Federativa do Brasil, e os institutos da Lei $\mathrm{n}^{\circ}$ 9.099/95, são alguns dos principais exemplos já existentes no ordenamento jurídico que possibilitam a aplicação da Mediação Penal no sistema penal, pois se tem um entendimento lato senso do instituto da conciliação previsto pela Lei ${ }^{\circ}{ }^{\circ}$ 9.099/95, portanto, abrangendo também a Mediação Penal nestes casos.

Em se tratando das Ações Penais Públicas Condicionadas à Representação e das Ações Penais Privadas, o processo de Mediação Penal também se torna uma oportunidade a ser dadas às partes, que se resultar neste momento processual em um acordo, provoca a renúncia à queixa ou representação.

Outra oportunidade vislumbrada neste trabalho para uso da Mediação Penal é a incidência do instituto da suspensão condicional do processo (artigo 89, caput, Lei ${ }^{\circ}$ 9.099/95) nas Ações Penais Públicas Condicionadas e Incondicionadas, através do cumprimento do requisito de reparação do dano pelo ofendido, previsto nos artigos 89, parágrafo $1^{\circ}$, inciso I, da Lei $n^{\circ} 9.099 / 95$.

Nos crimes mais graves, a Mediação Penal seria possível no sentido de oportunizar um diálogo entre as partes, buscando a preservação ou restauração do que foi desconstruído pelo conflito, mas não ao longo do processo, influenciando de alguma maneira a pena ou o direito de ação do Estado. Isto se dá em virtude de o processo ser nesses casos bem concentrado e pelo princípio da confidencialidade da Mediação visto nesta monografia.

Portanto, após todo o estudo realizado sobre o tema, nota-se a importância da aplicação da Mediação Penal dentro do atual sistema criminal, tendo não somente um 
valor jurídico, mas também social. Além disso, experiências vivenciadas pelo Direito brasileiro, como já ilustrado neste trabalho, mostraram a eficiência da aplicação deste instituto. De certo, que não se trata de um processo infalível; contudo, seu objetivo consiste em complementar o sistema tradicional da melhor maneira possível, de forma alternativa. 


\section{BIBLIOGRAFIA}

ALMEIDA, Tânia. Caixa de Ferramentas em Mediação: Técnicas e Procedimentos, Operacionalização das Intervenções e Impactos Esperados. $\quad<$ http://www.mediare.com.br/08artigos_15caixadeferramentas.html >. Acesso em 01/06/2010.

- Século XXI: A mediação de conflitos e outros métodos nãoadversariais de resolução de controvérsias.

<http://www.mediare.com.br/08artigos_02sec21.htm>.Acesso em 15/04/2010.

. Justiça Restaurativa e Mediação de Conflitos

$\langle$ http://www.mediare.com.br/08artigos_06justica_restaurativa.html $>$. Acesso em 09/05/2010.

. Mediação de Conflitos e Políticas Públicas.

http://www.mediare.com.br/08artigos 07mediacao_politicas_publicas.html. Acesso em $12 / 05 / 2010$

ARSÊNIO, Julieta. Mediação Penal - Realidade ou Utopia $\langle$ http://www.pailegal.net/mediation.asp?rvTextoId=1134424107> $>\quad$ (acesso em 10/03/2010).

AZEVEDO, André Gomma de. O Componente de Mediação Vítima-Ofensor na Justiça Restaurativa: Uma Breve Apresentação de uma Inovação Epistemológica na Autocomposição. Coletânea de Artigos. Slakmon, C., R. De Vitto, e R. Gomes Pinto, org., 2005. Justiça Restaurativa. Brasília - DF: Ministério da Justiça e Programa das Nações Unidas para o Desenvolvimento - PNUD. p.135-162. 
Justiça Restaurativa: Críticas e Contra críticas. Revista IOB de Direito

Penal e Processo Penal, Porto Alegre, vol. 8, n. 47, dez.2007/jan. 2008. p.158-189.

. Manual de Mediação Judicial. Brasília/DF: Ministério da Justiça e Programa das Nações Unidas para o Desenvolvimento - PNUD, 2009. 248 p.

BECCARIA, Cesare Bonesana. Dos delitos e das penas. $3^{\text {a }}$ ed. São Paulo: Martins Fontes, 2005. p.139.

BERISTAIN, Antonio. Nova Criminologia à luz do direito penal e da vitimologia. Trad. Cândido Furtado Mais Neto, Brasília, UnB, 2000.

BITENCOURT, Cezar Roberto. Tratado de Direito Penal: Parte Geral. Volume 1. $9^{\mathrm{a}}$ ed. São Paulo: Saraiva, 2004.

BRAITHWAITE, John. Restorative justice and responsive regulation. Nova Iorque: Oxford, 2002.

CARNEIRO, Breno Zaban. A indicação à mediação vítima-ofensor: algumas considerações em referência à sua eficácia em diferentes casos. Estudos em Arbitragem, Mediação e Negociação Vol 4 / André Gomma de Azevedo, Ivan Machado Barbosa (orgs.) - Brasília: Grupos de Pesquisa, 2007. p. 221-236.

DA SILVA, José Afonso. Curso de Direito Constitucional Positivo. $19^{a}$ ed. São Paulo. Editora Malheiros, 2001. p.218-225.

DE VITTO, Renato Campos Pinto. Justiça Criminal, Justiça Restaurativa e Direitos Humanos. Coletânea de Artigos. Slakmon, C., R. De Vitto, e R. Gomes Pinto, org., 2005. Justiça Restaurativa. Brasília - DF: Ministério da Justiça e Programa das Nações Unidas para o Desenvolvimento - PNUD. p.41-51. 
DURKHEIM, Emile. Dos leyes de La evolución penal. Delito y Sociedad. Revista de Ciencias Sociales, número 13. Buenos Aires, 1999. p. 71-90.

EIRAS NORDENSTAHL, Ulf Christian. Médiacion Penal: de La Práctica a La Teoría. Buenos Aires: Librería Histórica, 2005. 232 p.

FILHO, Maurício Vasconcelos Galvão; WEBER, Ana Carolina. Disposições gerais sobre a mediação civil. Teoria Geral da Mediação à Luz do Projeto de Lei e do Direito Comparado. Rio de Janeiro: Lumen Juris, 2008. p. 3- 58.

FOUCAULT, Michel. Vigiar e Punir: Nascimento da prisão. $31^{\text {a }}$ ed. Petrópolis: Editora Vozes, 2005. p.12-14.

MIRABETE, Julio Fabbrini. Manual de Direito Penal: Parte Geral, Volume I. $22^{\mathrm{a}}$ ed. São Paulo: Atlas, 2005. p. 32-37

PAZ, Silvina Marcela; PAZ, Silvana Sandra. Justiça Restaurativa - Processos Possíveis.

Coletânea de Artigos. Slakmon, C., R. De Vitto, e R. Gomes Pinto, org., 2005. Justiça Restaurativa. Brasília - DF: Ministério da Justiça e Programa das Nações Unidas para o Desenvolvimento - PNUD. p.125-130.

. Mediação Penal - Verdade - Justiça Restaurativa. Coletânea de Artigos. Slakmon, C., R. De Vitto, e R. Gomes Pinto, org., 2005. Justiça Restaurativa. Brasília DF: Ministério da Justiça e Programa das Nações Unidas para o Desenvolvimento PNUD. p.131-134.

PINHO, Humberto Dalla Bernardina de (cord). Teoria Geral da mediação à luz do projeto de lei e do direito comparado. Rio de Janeiro: Lumen Juris, 2008. p.241-292.

PINTO, Renato Sócrates Gomes. Justiça Restaurativa é Possível no Brasil?. Coletânea de Artigos. Slakmon, C., R. De Vitto, e R. Gomes Pinto, org., 2005. Justiça Restaurativa. 
Brasília - DF: Ministério da Justiça e Programa das Nações Unidas para o Desenvolvimento - PNUD. p.19-39.

PIRES, Álvaro. A racionalidade penal moderna, o público e os direitos humanos. Novos Estudos CEBRAP. n. 68. São Paulo, CEBRAP, 2004. p. 39-60.

SICA, Leonardo. O Novo Modelo de Justiça Criminal e de Gestão do Crime. Rio de Janeiro: Lumen Juris, 2007. 263 p.

Slakmon, C., R. De Vitto, e R. Gomes Pinto. Prefácio. Coletânea de Artigos. Slakmon, C., R. De Vitto, e R. Gomes Pinto, org., 2005. Justiça Restaurativa. Brasília - DF: Ministério da Justiça e Programa das Nações Unidas para o Desenvolvimento - PNUD. p.135-162.

TIAGO, Tatiana Sandy. Implementação da Justiça Restaurativa por meio da mediação penal. Estudos em Arbitragem, Mediação e Negociação Vol 4 / André Gomma de Azevedo, Ivan Machado Barbosa (orgs.) - Brasília: Grupos de Pesquisa, 2007.

UMBREIT, Mark S.; ROBERTS, A.W. 1996.Mediation of criminal conflict in England: an assessment of services in Coventry and Leeds. St. Paul, MN: Center for Restorative Justice \& Mediation, University of Minnesota. In: UMBREIT, 1998.

$<$ http://www.trf3.jus.br/NXT/Gateway.dll?f=templates\&fn=default.htm\&vid=trf3e:trf3ve $>$

(acesso em 16/05/2010)

UMBREIT, Mark S. The Handbook of Victim Offender Mediation: An Essential Guide to Practice and Research. São Francisco, CA: Jossey Bass, 2001.

- Justiça Restaurativa por meio da mediação vítima-ofensor: uma avaliação a partir de várias experiências locais. Estudos em Arbitragem, Mediação e Negociação Vol 4 / André Gomma de Azevedo, Ivan Machado Barbosa (orgs.) Brasília: Grupos de Pesquisa, 2007. p. 65-92. 
VASCONCELOS, Carlos Eduardo de. Mediação de conflitos e práticas restaurativas. São Paulo: Método, 2008. 206 p.

TRF $3^{\text {a }}$ Região, Quinta Turma, - HABEAS CORPUS - 16133, Rel. Desembargador Federal Andre Nabarrete, São Paulo, 15 de mar. 2004. 


\section{ANEXOS}

PROJETO DE LEI DA CÂMARA N ${ }^{\circ}$ 94, DE 2002

( $n^{\circ} 4.827 / 98$, na Cámara dos Deputados)

Institucionaliza e disciplina a

mediapão, como método de prevencero

- soluçilo consensual de conelitos.

- CONGRESSO NaCIONAL decreta :

Art. $1^{\text {क }}$ para os fins desta tei, mediagão á a atividade tócnica exercida por terceira posnoa, que, escolhida ou aceita pelas partes interessadas, as escuta e orienta ecen o propobsto de lhes permitir que, de modo consensual, previnam ou solucionem conflitos.

Parágrafo unicico. É licita a mediaçĭo en toda matéria que admita conciliaçäo, reconciliação, transação, ou acordo de outra oxdem, para os fins que consinta a lei civil ou penal.

Art. $2^{\circ}$ Podo sor modiador qualquer pessos capaz e que tenha formaç̣̂o técnica ou experiência prática adequada a naturoa do conflito.

$51^{\circ}$ Pode sê-1o também a pessoa juridica quo, nos ternos do objeto social, se dedique ao exerciaio da mediaçẩo por intermédio de pessoas fisicas que atendam às oxigencias deste artigo.

S $2^{\circ}$ No desempenho de sua funclio, o mediador deverá proceder com imparcialidade, independêneía, conpetên= eia, diligência e sigilo.

Art. $3^{\circ}$ A mediação é judicial ou extrajudieial, podendo versar sobre todo o conflito ou parto dele.

Art. $4^{*} \mathrm{Em}$ qualquer tempo o grau de juriadiçầ, pode o juiz buscar convencer as partes da conveniência do se submetorem a modiaçào extrajudicial, ou, com a conoordâneia delas, designar mediador, suspendendo o processo pelo prazo de até três meses, prorrogavel por 1 gra 1 periodo.

Parágrafo único. o mediador judicial está sujeito a coapromisso, mas pode escusar-so ou ser recusado por qualquer das partes, en cinco dias da designação, aplicando-se-1he, no que caibam, as normas que regulan a responaabilidado o a romuneração dos peritos. 


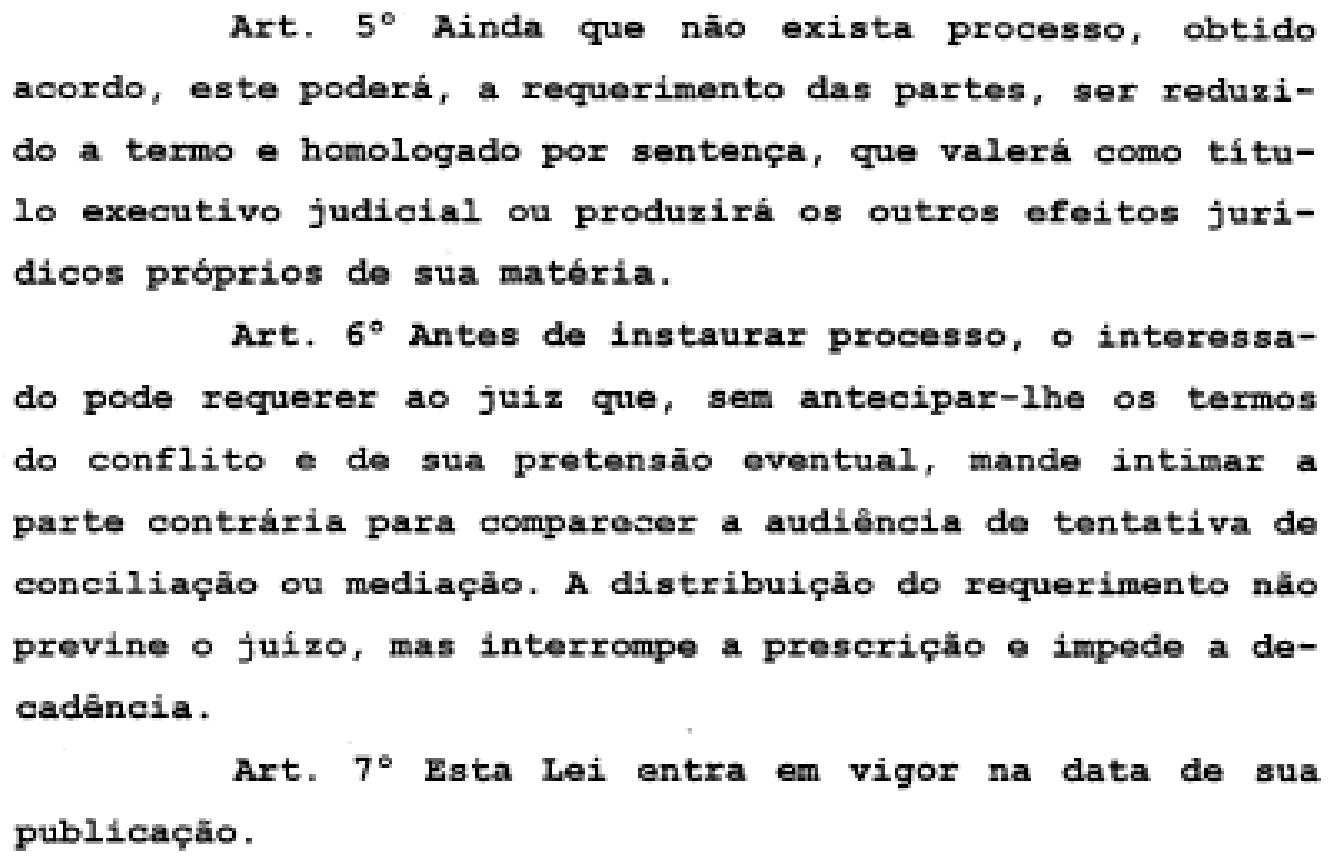

\section{PROJETO DE LEI ORIGINAL Nº 4.827 , DE 1998}

Institucionaliza e disciplina a mediaçâo, com método de prevençăo e soluçăo consensual de confiltos;

O Congresso Nacional decreta:

ART. $1^{\circ}$ - Para os fins desta lei, mediação et a atividade técnica exercida por terceira pessoa, que escolhida ou aceita peias partes interessadas, as escuta e orienta com o proposito de thes permitir que, de modo consensual, previnam ou solucionen conflitos.

Parágrafo único - É licita a mediaçăo em toda matéria que admita conciliação, reconciliação, transação, ou acordo de outra ordem, para os fins que consinta a lei civil ou penal.

ART. $2^{\circ}$ - Pode ser mediadior qualquer pessoa capaz e que tenha formação técnica ou experiència prática adequada à natureza do conflito.

$\S 1^{\circ}$ - Pode sé-lo também a pessoe juridica que nos termos do objeto social, se dedique ao exercicio da mediaçăo por intermédio de pessoas fisicas que atendam as
ex'gências deste artigo.

$\$ 2^{\circ}$ - No desempenho de sua funçı̆o, o mediador deverá procedêr. com imparcialidade, independéncia, competència, diligência e sigilo. 
ART. $3^{\circ}$ - A mediaçăo é judicial ou extrajudicial, podendo versar sobre todo o conflito ou parte dele.

ART. $4^{\circ}$ - Em qualquer tempo e grau de jurisdição, pode o juiz buscar convencer as partes da conveniencia de se submeterem a mediaçåo extrajudicial, ou, com a concordância delas, designar mediador, suspendendo o processo pelo prazo de até 3 (trés) meses, prorrogável por igual periodo.

Parágrafo único - O mediador judicial está sujeito a compromisso, mas pode escusar-se ou ser recusado por qualquer das partes, em cinco dias da designação. Aplicam-se-lhe, no que caibam, as normas que regulam a responsabilidade e a remuneração dos neritos.

ART. $5^{\circ}$ - Ainda que não exista processo, obtido acordo, este poderá, a requerimento das partes, ser reduzido a termo e homologado por sentença, que valerá como titulo executivo judicial ou produzirá os outros efeitos jurídicos próprios de sua matéria.

ART. $6^{\circ}$ - Antes de instaurar processo, o interessado pode requerer ao juiz que, sem antecipar-lhe os termos do conflitos e de sua pretensão eventual, mande intimar a parte contrária para comparecer a audiência de tentativa de conciliação ou mediação. A distribuiçẫo do requerimento năo previne o juizo, mas intertompe a prescrição e impede a decadència.

ART. $7^{\circ}$ - Esta lei entra entra em vigor à data de sugpublicaçăo.

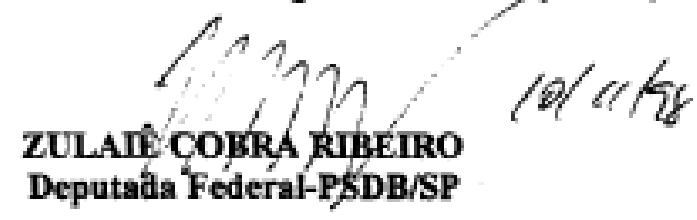




\section{CÓDIGO DE ÉTICA DOS CONCILIADORES E MEDIADORES}

Este Código de Ética se aplica à conduta de todos os conciliadores e mediadores. Nos termos aprovados pelo CONIMA - Conselho Nacional das Instituições de Mediação e Arbitragem -, com as devidas adaptações ao funcionamento das Centrais e Câmaras de Conciliação, Mediação e Arbitragem.

\section{I - AUTONOMIA DA VONTADE DAS PARTES}

A mediação fundamenta-se na autonomia da vontade das partes, devendo o conciliador ou mediador concentrar a sua atuação nessa premissa.

Nota explicativa

O caráter voluntário do procedimento de conciliação ou mediação garante o poder das partes de administrá-lo, estabelecer diferentes procedimentos e a liberdade de tomar as próprias decisões durante ou ao final do processo.

\section{II - PRINCÍPIOS FUNDAMENTAIS}

O conciliador ou mediador pautará sua conduta nos seguintes princípios:

Imparcialidade, Credibilidade, Competência, Confidencialidade e Diligência.

Notas Explicativas

Imparcialidade - condição fundamental ao mediador; não pode existir qualquer conflito de interesses ou relacionamento capaz de afetar sua imparcialidade; deve procurar compreender a realidade dos litigantes, sem que nenhum preconceito ou valores pessoais venham a interferir no seu trabalho.

Credibilidade - $\mathrm{O}$ conciliador ou mediador deve construir e manter a credibilidade perante as partes, sendo independente, franco e coerente.

Competência - a capacidade para efetivamente conciliar ou mediar a controvérsia existente. Por isso o mediador somente deverá aceitar a tarefa quando tiver as qualificações necessárias para satisfazer as expectativas razoáveis das partes.

Confidencialidade - os fatos, situações e propostas ocorridos durante a conciliação ou a mediação são sigilosos e privilegiados. Aqueles que participarem do processo devem obrigatoriamente manter o sigilo sobre todo conteúdo a ele referente, não podendo ser testemunhas do caso, respeitado o princípio da autonomia da vontade das partes, nos termos por elas convencionados, desde que não contrarie a ordem pública.

Diligência - cuidado e a prudência para a observância da regularidade, assegurando a 
qualidade do processo e cuidando ativamente de todos os seus princípios fundamentais.

\section{III - DO CONCILIADOR OU MEDIADOR FRENTE À SUA MISSÃO}

1. Aceitará o encargo somente se estiver imbuído do propósito de atuar de acordo com os Princípios Fundamentais estabelecidos e Normas Éticas, mantendo íntegro o processo de conciliação ou mediação.

2. Revelará, antes de dar início ao seu trabalho, interesse ou relacionamento que possa afetar a imparcialidade, suscitar aparência de parcialidade ou quebra de independência, para que as partes tenham elementos de avaliação e decisão sobre sua continuidade.

3. Avaliará a aplicabilidade ou não de conciliação ou mediação ao caso.

\section{IV - DO CONCILIADOR OU MEDIADOR FRENTE ÀS PARTES}

1. Garantir às partes a oportunidade de entender e avaliar as implicações e o desdobramento do processo e de cada item negociado nas entrevistas preliminares e no curso da conciliação ou da mediação;

2. Utilizar a prudência e a veracidade, abstendo-se de promessas e garantias a respeito dos resultados;

3. Dialogar separadamente com uma parte somente quando for dado o conhecimento e igual oportunidade à outra;

4. Esclarecer à parte, ao finalizar uma sessão em separado, quais os pontos sigilosos e quais aqueles que podem ser do conhecimento da outra parte;

5. Assegurar-se que as partes tenham voz e legitimidade no procedimento, garantindo assim equilíbrio de poder;

6. Assegurar-se de que as partes tenham suficientes informações para avaliar e decidir;

7. Recomendar às partes uma revisão legal do acordo antes de subscrevê-lo.

8. Eximir-se de forçar a aceitação de um acordo e/ou tomar decisões pelas partes.

9. Observar a restrição de não atuar como profissional contratado por qualquer uma das partes, para tratar de questão que tenha correlação com a matéria objeto de sua atividade como conciliador ou mediador.

\section{V - DO CONCILIADOR OU MEDIADOR FRENTE AO PROCEDIMENTO DE CONCILIAÇÃO OU MEDIAÇÃO}

1. Descrever o processo de conciliação ou mediação para as partes;

2. Esclarecer quanto ao sigilo;

3. Assegurar a qualidade do processo, utilizando todas as técnicas disponíveis e capazes de levar a bom termo os objetivos da conciliação ou da mediação;

4. Zelar pelo sigilo dos procedimentos, inclusive no concernente aos cuidados a serem 
tomados pela equipe técnica no manuseio e arquivamento dos dados;

5. Sugerir a busca e/ou a participação de especialistas na medida em que suas presenças se façam necessárias a esclarecimentos para a manutenção da equanimidade;

6. Interromper o procedimento frente a qualquer impedimento ético ou legal; 7. Suspender ou finalizar a conciliação ou a mediação quando concluir que sua continuação possa prejudicar terceiros ou quando houver solicitação das partes; 8. Fornecer às partes, por escrito, as conclusões da conciliação ou da mediação, quando por elas solicitado.

\section{VI - DO CONCILIADOR OU MEDIADOR FRENTE À CENTRAL OU CÂMARA DE CONCILIAÇÃO, MEDIAÇÃO E ARBITRAGEM}

1. Cooperar para a qualidade dos serviços prestados pela CENTRAL OU CÂMARA DE CONCILIAÇÃO, MEDIAÇÃO E ARBITRAGEM;

2. Manter os padrões de qualificação, de formação, aprimoramento e especialização exigidos pela CENTRAL OU CÂMARA DE CONCILIAÇÃO, MEDIAÇÃO E ARBITRAGEM;

3. Acatar as normas institucionais e éticas da profissão;

4. Submeter-se a este Código de Ética, comunicando à Coordenação das CCCMA qualquer violação às suas normas. 


\section{REGULAMENTO - MODELO PARA MEDIAÇÃO}

\section{APRESENTAÇÃO}

As decisões de consenso obtidas por meio da composição são cada vez mais eficazes para a solução das controvérsias. Para tal resultado, é possível valer-se da Mediação.

A Mediação é um Processo não-adversarial e voluntário de resolução de controvérsias por intermédio do qual duas ou mais pessoas, físicas ou jurídicas, buscam obter uma solução consensual que possibilite preservar o relacionamento entre elas. Para isso, recorrem a um terceiro facilitador, o Mediador-especialista imparcial, competente, diligente, com credibilidade e comprometido com o sigilo; que estimule, viabilize a comunicação e auxilie na busca da identificação dos reais interesses envolvidos.

O Mediador, através de uma série de procedimentos e de técnicas próprias, identifica os interesses das partes e constrói com elas, sem caráter vinculativo, opções de solução, visando ao consenso e/ou à realização do acordo.

A Mediação envolve aspectos emocionais, relacionais, negociais, legais, sociológicos, entre outros. Assim, quando necessário, para atender às peculiaridades de cada caso, também poderão participar do Processo profissionais especializados nos diversos aspectos que envolvam a controvérsia, permitindo uma solução interdisciplinar por meio da complementaridade do conhecimento.

Co-mediação é o processo realizado por dois (ou mais mediadores) e que permite uma reflexão e amplia a visão da controvérsia, propiciando um melhor controle da qualidade da Mediação.

A opção pela Mediação prestigia o poder dispositivo das partes, possibilita a celeridade na resolução das controvérsias e reduz os custos. Os procedimentos são confidenciais e a responsabilidade das decisões cabe às partes envolvidas. A Mediação possui características próprias que a diferenciam de outras formas de Resolução de controvérsias, possibilitando inclusive estabelecer, a priori, a futura adoção da arbitragem.

O compromisso com as pessoas envolvidas na controvérsia, a importância do instituto para a sociedade e a seriedade imprescindível ao seu exercício exigem do Mediador uma formação adequada e criteriosa que o habilite.

Mediação é um acordo de vontades ( motivo pelo qual deverá ser objeto de um contrato sempre que for instalado seu procedimento) que prescinde de regulamentação legal, 
muito embora se faça necessário alcançar uma desejável uniformidade dos seus princípios e regras gerais.

\section{PRINCÍPIOS BÁSICOS}

São PRINCÍPIOS BÁSICOS a serem respeitados no Processo da Mediação:

- o caráter voluntário;

- o poder dispositivo das partes, respeitando o princípio da autonomia da vontade, desde que não contrarie os princípios de ordem pública;

- a complementariedade do conhecimento;

- a credibilidade e a imparcialidade do Mediador;

- a competência do Mediador, obtida pela formação adequada e permanente;

- a diligência dos procedimentos;

- a boa fé e a lealdade das práticas aplicadas;

- a flexibilidade, a clareza, a concisão e a simplicidade, tanto na linguagem quanto nos procedimentos, de modo que atendam à compreensão e às necessidades do mercado para o qual se voltam;

- a possibilidade de oferecer segurança jurídica, em contraponto à perturbação e ao prejuízo que as controvérsias geram nas relações sociais;

- a confidencialidade do processo.

\section{NOTAS EXPLICATIVAS}

Estas regras são aplicáveis para o Processo de Mediação de controvérsias surgidas de contratos e outras relações sociais, escolhido pelas partes que buscam um acordo.

O presente regulamento, em conjunto com o Código de Ética dos Mediadores, se aplica a todas as Mediações, ou seja, àquelas organizadas por instituições ou entidades especializadas e, "ad hoc", assim entendida a Mediação que for realizada por 
profissional escolhido pelas partes, desvinculado de qualquer instituição ou entidade, em tudo o que for compatível.

Recomenda-se a todas as instituições e entidades, governamentais e privadas, organizadas para o serviço da Mediação, assim como a todos os Mediadores "ad hoc", que pautem sua atuação pelo Regulamento Modelo da Mediação e o Código de Ética dos Mediadores.

\section{CAPÍTULO I - INÍCIO DO PROCESSO}

Art. $1^{\circ}$ - Qualquer pessoa jurídica ou física capaz pode requerer a Mediação para solução de uma controvérsia a instituições ou entidades especializadas, ou a Mediadores ad hoc.

Art. $2^{\mathbf{o}}$ - A solicitação da Mediação, bem como o convite à outra parte para dela participar, deverão, preferencialmente, ser formulados por escrito.

Art. $3^{\mathbf{0}}$ - Quando a outra parte não concordar em participar da Mediação, a primeira será imediatamente comunicada por escrito.

I. Recomenda-se que o período compreendido entre a procura inicial e a entrevista de Pré-Mediação (Art 5 o) não ultrapasse 30 (trinta) dias.

\section{CAPÍTULO II - REPRESENTAÇÃO E ASSESSORAMENTO}

Art. $4^{\mathbf{0}}$ - As partes deverão participar do Processo pessoalmente. Na impossibilidade comprovada de fazê-lo, podem se fazer representar por uma outra pessoa com procuração que outorgue poderes de decisão.

As partes podem se fazer acompanhar por advogados e outros assessores técnicos e por pessoas de sua confiança ou escolha, desde que estas presenças sejam convencionadas entre as partes e consideradas pelo Mediador úteis e pertinentes ao necessário equilíbrio do processo.

\section{CAPÍTULO III - PREPARAÇÃO (Pré-Mediação)}

Art. $5^{\circ}$ - O Processo iniciará com uma entrevista (Pré-Mediação) que cumprirá os seguintes procedimentos: 
I. as partes deverão descrever a controvérsia e expor as suas expectativas;

II. as partes serão esclarecidas sobre o processo da Mediação, seus procedimentos e suas técnicas;

III. as partes deliberarão se adotarão ou não a Mediação como método de resolução de sua controvérsia;

IV. as partes escolherão o Mediador, nos termos do Capítulo IV, que poderá ser ou não aquele que estiver coordenando os trabalhos da entrevista.

Recomenda-se que o período compreendido entre a entrevista de Pré-Mediação e aquela que propiciará a negociação de procedimentos e a assinatura do Termo de Mediação não ultrapasse 15 (quinze) dias.

Art. $6^{\mathbf{0}}$ - Reunidas após a escolha do Mediador, e com a sua orientação, as partes devem firmar o contrato (Termo de Mediação) onde fiquem estabelecidos:

I. a agenda de trabalho;

II. os objetivos da Mediação proposta;

III. as normas e procedimentos, ainda que sujeitos à redefinição negociada a qualquer momento durante o processo, a saber:

- extensão do sigilo no que diz respeito à instituição, ao mediador, às partes e demais pessoas que venham a participar do processo;

- estimativa do seu tempo de duração, frequiência e duração das reuniões;

- normas relativas às reuniões privadas e conjuntas;

- procedimentos relativos aos documentos aportados à Mediação e aos apontamentos produzidos pelos mediadores;

IV. as pessoas que as representarão, mediante procuração com poderes de decisão expressos, ou as acompanharão, se for o caso;

V. o lugar e o idioma da Mediação, ou, se assim o desejarem, deixar a critério da instituição ou entidade organizadora do serviço;

VI. os custos e forma de pagamento da Mediação, observado o disposto nos artigos 16 e 17 ; 
VII. o nome dos mediadores e, se for o caso, da instituição promotora.

\section{CAPÍTULO IV - ESCOLHA DO MEDIADOR}

Art. $7^{\mathbf{0}}$ - O Mediador será escolhido livremente pelas partes em lista de Mediadores oferecida por instituição ou entidade organizadora do serviço ou, se as partes assim o desejarem, indicado pela referida instituição ou entidade; ou ainda, profissional escolhido pelas partes:

I. o(s) mediador(es) escolhido(s) pelas partes não pertencente(s) à entidade organizadora, estará(ão) sujeito(s) à aprovação da referida entidade;

II. o(s) mediador(es) eleito(s) pelas partes manifestará(ão) sua aceitação e firmará(ão) o Termo de Independência relativo à sua atuação.

Se, no curso da Mediação, sobrevier algum impedimento ou impossibilidade de participação do mediador, haverá a escolha de novo mediador segundo o critério eleito pelas partes.

Art. $\mathbf{8}^{\mathbf{o}}$ - O Mediador único escolhido poderá recomendar a co-mediação, sempre que julgar benéfica ao propósito da Mediação.

\section{CAPÍTULO V - ATUAÇÃO DO MEDIADOR}

Art. $9^{\circ}$ - As reuniões de Mediação serão realizadas preferencialmente em conjunto com as partes.

Parágrafo Único: havendo necessidade e concordância das partes, o Mediador poderá reunir-se separadamente com cada uma delas, respeitado o disposto no Código de Ética dos Mediadores quanto à igualdade de oportunidades e quanto ao sigilo nessa circunstância.

Art. $\mathbf{1 0}^{\circ}$ - O Mediador poderá conduzir os procedimentos da maneira que considerar apropriada, levando em conta as circunstâncias, o estabelecido na negociação com as partes e a própria celeridade do processo.

Art. $1^{\circ}$ - O Mediador cuidará para que haja equilíbrio de participação, informação e poder decisório entre as partes. 
Art. $1^{\circ}$ - Salvo se as partes dispuserem em contrário, ou a lei impedir, o Mediador pode:

I. aumentar ou diminuir qualquer prazo;

II. interrogar o que entender necessário para o bom desenvolvimento do Processo;

III. solicitar às partes que deixem à sua disposição tudo o que precisar para sua própria inspeção ou de qualquer perito, bem como a apresentação de documento ou classe de documentos que se encontrem em sua posse, custódia ou poder de disposição, desde que entenda relevante para sua análise, ou por qualquer das partes;

IV. solicitar às partes que procurem toda informação técnica e legal necessária para a tomada de decisões.

\section{CAPÍTULO VI - IMPEDIMENTOS E SIGILO}

Art. $1^{\circ}$ - O Mediador fica impedido de atuar ou estar diretamente envolvido em procedimentos subseqüentes à Mediação, tais como na Arbitragem ou no Processo Judicial quando a Mediação obtiver êxito ou não, a menos que as partes disponham diferentemente.

Art. $1^{\mathbf{0}}$ - As informações da Mediação são confidenciais e privilegiadas. O Mediador, qualquer das partes, ou outra pessoa que atue na Mediação, não poderão revelar a terceiros ou serem chamados ou compelidos, inclusive em posterior Arbitragem ou Processo Judicial, a revelar fatos, propostas e quaisquer outras informações obtidas durante a Mediação.

Art. $1^{\circ}$ - Os documentos apresentados durante a Mediação deverão ser devolvidos às partes, após análise. Os demais deverão ser destruídos ou arquivados conforme o convencionado.

\section{CAPÍTULO VII - DOS CUSTOS}

Art. $1^{\circ}$ - Os custos, assim consideradas as despesas administrativas e os honorários do Mediador, serão rateados entre as partes, salvo disposição em contrário. No caso da Mediação realizada por instituição ou entidade especializada, estes custos deverão seguir as respectivas tabelas. 
Art. $1^{\mathbf{0}}$ - Os honorários do Mediador deverão ser acordados previamente e poderão ser estabelecidos por hora trabalhada ou outro critério definido com as partes. Quando a Mediação for realizada por meio de instituição ou entidade especializada, serão adotadas as respectivas tabelas.

\section{CAPÍTULO VIII - RESPONSABILIDADE DO MEDIADOR}

Art. $\mathbf{1 8}^{\mathbf{0}}$ - O Mediador não pode ser responsabilizado por qualquer das partes por ato ou omissão relacionada com a Mediação conduzida de acordo com as normas éticas e regras com as partes acordadas.

\section{CAPÍTULO IX - DO ACORDO}

Art. $1^{\circ}$ - Os acordos constituídos na mediação podem ser totais ou parciais.

Caso alguns itens da pauta de mediação não tenham logrado acordo, o mediador poderá atuar na negociação destinada a auxiliar as partes a elegerem outros meios extrajudiciais ou judiciais para a sua resolução.

Art. $2^{\circ}$ - Em consonância com o desejo das partes, os acordos obtidos na mediação podem ser informais ou constituírem-se títulos executivos extrajudiciais incorporando a assinatura de duas testemunhas, preferencialmente os advogados das partes ou outra(s) por elas indicadas.

Se as partes assim o desejarem, os acordos poderão ganhar linguagem jurídica para serem homologados judicialmente. Nestes casos, os mediadores deverão manter-se disponíveis para auxiliar na manutenção da fidelidade ao texto original.

\section{CAPÍTULO X - ENCERRAMENTO}

Art. $21^{\circ}$ - O Processo de Mediação encerra-se:

I. com a assinatura do termo de acordo pelas partes;

II. por uma declaração escrita do Mediador, no sentido de que não se justifica aplicar mais esforços para buscar a composição; 
III. por uma declaração conjunta das partes, dirigida ao Mediador com o efeito de encerrar a Mediação;

IV. por uma declaração escrita de uma parte para a outra, e para o Mediador, com o efeito de encerrar a Mediação.

\section{CAPÍTULO XI - DISPOSIÇÕES FINAIS}

Art. $\mathbf{2 0}^{\circ}$ - É recomendável que as partes passem a inserir Cláusula de Mediação nos contratos em geral que venham a firmar, tal como o modelo proposto:

Se uma controvérsia surgir em razão deste contrato ou posteriores adendos, incluindo, sem limitação, o seu descumprimento, término, validade ou invalidade, ou qualquer questão relacionada com o mesmo, as partes convencionam, desde já, que primeiramente irão buscar uma solução por meio da Mediação, fundada no princípio da boa fé, antes de recorrer a outros meios judiciais ou extrajudiciais para resolução de controvérsias.

Art. $21^{\circ}$ - Caberá às partes deliberarem sobre lacunas do presente regulamento, podendo delegar essa tarefa à instituição ou entidade especializada a que estiver vinculada a Mediação, se assim o desejarem. 


\section{ATO EXECUTIVO TJ Nº 5555, de 10/12/2009 (ESTADUAL) \\ DJERJ, ADM $66(8)$ - 10/12/2009}

\section{ATO EXECUTIVO N 5555/2009}

O Presidente do Tribunal de Justiça do Estado do Rio de Janeiro, no uso de suas atribuições legais;

CONSIDERANDO que o Estado brasileiro adotou solenemente em sua Carta Magna a solução pacífica dos conflitos, como um dos princípios regentes das relações entre os povos, sendo objetivo fundamental da República a construção de uma sociedade livre, justa e solidária;

CONSIDERANDO que a mediação tem por escopo a otimização da solução dos conflitos, a prevenção de litígios, a inclusão social pela valorização do ser humano e pelo respeito aos direitos fundamentais;

CONSIDERANDO a necessidade de implantação no Poder Judiciário de métodos alternativos de resolução de conflitos, observando-se a demanda da lide sociológica para além da lide processual;

CONSIDERANDO a mediação como método de resolução pacífica de disputas, por intermédio de processo autocompositivo;

CONSIDERANDO que a mediação é particularmente indicada em conflitos decorrentes de relações continuadas entre as partes, principalmente as familiares, em cuja solução a qualidade da relação social deve ser resguardada;

CONSIDERANDO o Convênio MJ Nº 82/2008 para realização de cursos de capacitação e aperfeiçoamento em técnicas de mediação e composição de conflitos para magistrados e servidores deste Tribunal, firmado com o Ministério da Justiça, por intermédio da Secretaria de Reforma do Judiciário, Processo MJ No 08025.000735/2008-22, Termo $\mathrm{N}^{\mathrm{o}}$ 003/1124/2008, Processo TJRJ No 313487/2008;

CONSIDERANDO, ainda, os excelentes estudos apresentados pelo Grupo de Trabalho de Soluções Alternativas para Busca de Resolução de Conflitos do Tribunal de Justiça do Estado do Rio de Janeiro, que resultou no anteprojeto de Resolução regulamentando a atividade de mediação no âmbito do Poder Judiciário, tramitando no Órgão Especial deste E. Tribunal de Justiça sob o nº 2009/287748; 


\section{R E S O L V E:}

Art. $1^{\circ}$ Fica instalado o CENTRO DE MEDIAÇÃO DO FORUM CENTRAL DA COMARCA DA CAPITAL, que funcionará no Palácio da Justiça, na Av. Erasmo Braga, $n^{\circ}$ 115, Lâmina I, $2^{\text {o }}$ andar, Corredor D, Sala 223, a partir de 10 de dezembro de 2009, com competência para atender os casos encaminhados pelos Juízes de Direito das Varas de Família da Comarca da Capital.

Parágrafo Único. Quando da indicação do caso para mediação, que dependerá do consentimento dos envolvidos, as partes e advogados deverão ser informados pelo Juízo de origem das características do trabalho, especialmente sobre a gratuidade e o caráter sigiloso.

Art. $2^{\circ} \mathrm{O}$ Centro de Mediação do Fórum Central da Comarca da Capital será dirigido por Juiz de Direito, nomeado pela Presidência do Tribunal de Justiça, dentre os Juízes de Direito Titulares das Varas de Família da Comarca da Capital.

Art. $3^{\circ}$ A Presidência do Tribunal de Justiça, por indicação do Juiz de Direito Diretor do Centro de Mediação do Fórum Central da Comarca da Capital, nomeará servidor que exercerá a função de Coordenador do Centro de Mediação, sem prejuízo de suas demais funções, nem de sua lotação.

Art. $4^{\circ}$ As equipes de mediação serão compostas por mediadores designados por Portaria do Juiz de Direito Diretor, dentre aqueles que necessariamente estiverem inseridos no processo de certificação, a ser regulamentado pelo E. Órgão Especial, após consulta a Presidência do Subgrupo de Trabalho para Conciliação e Mediação do Tribunal de Justiça do Estado do Rio de Janeiro.

Parágrafo Único. A designação das equipes se fará, preferencialmente, em rodízio, observando-se a disponibilidade de horários e sua adequação às necessidades das partes.

Art. $5^{\circ} \mathrm{O}$ controle de processos para mediação caberá ao Coordenador do Centro de Mediação, o qual se responsabilizará pelo acompanhamento administrativo dos trabalhos desenvolvidos e do encaminhamento dos relatórios aos Mediadores Supervisores, indicados pela Presidência do Subgrupo de Trabalho para Conciliação e Mediação do Tribunal de Justiça do Estado do Rio de Janeiro.

Art. $6^{\circ} \mathrm{O}$ quadro de controle de processos deverá ser atualizado mensalmente pelo Coordenador do Centro de Mediação, e informado ao Juiz de Direito Diretor. 
Art. $7^{\circ}$ O Subgrupo de Trabalho para Conciliação e Mediação prestará auxílio administrativo e técnico ao Centro de Mediação do Fórum Central da Comarca da Capital, por intermédio do DEACO - Departamento de Apoio aos Órgãos Colegiados Não-Jurisdicionais do Gabinete da Presidência.

Art. $8^{\circ}$ Quaisquer dúvidas acerca dos procedimentos concernentes a mediação que não estejam regulamentadas por este Ato Executivo serão dirimidas pelos Presidentes do Grupo de Trabalho de Soluções Alternativas para Busca de Resolução de Conflitos e do Subgrupo de Trabalho para Conciliação e Mediação do Tribunal de Justiça do Estado do Rio de Janeiro.

Art. $9^{\circ}$ Sob a presidência do Juiz de Direito Diretor designado, o Coordenador do Centro de Mediação lavrará a Ata de Instalação, remetendo cópia ao Presidente do Tribunal de Justiça e ao Corregedor-Geral da Justiça.

Art. $10^{\circ} \mathrm{O}$ presente Ato entrará em vigor na data da sua publicação, revogando as disposições em contrário.

Rio de Janeiro, 10 de dezembro de 2009.

DESEMBARGADOR LUIZ ZVEITER

PRESIDENTE 
ATO EXECUTIVO TJ No 1597, de 15/04/2010 (ESTADUAL)

DJERJ, ADM 146 (4) - 16/04/2010

\section{ATO EXECUTIVO N $1597 / 2010$}

O Presidente do Tribunal de Justiça do Estado do Rio de Janeiro, no uso de suas atribuições legais;

CONSIDERANDO que a mediação tem por escopo a otimização da solução dos conflitos, a prevenção de litígios, a inclusão social pela valorização do ser humano e pelo respeito aos direitos fundamentais;

CONSIDERANDO a mediação como método de resolução pacífica de disputas, por intermédio de processo autocompositivo;

CONSIDERANDO a necessidade de implantação no Poder Judiciário de métodos alternativos de resolução de conflitos, observando-se a demanda da lide sociológica para além da lide processual;

CONSIDERANDO a expedição da Resolução TJ/OE nº 19/2009 que dispõe sobre a regulamentação da atividade de Mediação no âmbito do Poder Judiciário do Estado do Rio de Janeiro;

CONSIDERANDO a expedição do Ato Executivo $\mathrm{n}^{\circ}$ 5555/2009 que trata do funcionamento do Centro de Mediação no Fórum Central e dá outras providências;

R E S O L V E

Art. $1^{\circ}$ Ficam instalados os centros de mediação abaixo relacionados, que passam a funcionar a partir de 16 de abril de 2010, no atendimento aos processos encaminhados pelos Juízes de Direito em exercício na respectiva área atendida pelo fórum regional ou comarca:

Capital - Fórum Regional da Barra da Tijuca - Avenida Luiz Carlos Prestes, s/n $\mathrm{n}^{\mathrm{o}}-1^{\mathrm{o}}$ andar - Barra da Tijuca

Capital - Fórum Regional de Campo Grande - Rua Carlos da Silva Costa, 141 - $3^{\circ}$ andar Campo Grande

Capital - Fórum Regional de Jacarepaguá - Rua Professora Francisca Piragibe, 80 - $2^{\circ}$ andar - Taquara 
Capital - Fórum Regional de Madureira - Avenida Ernani Cardoso, 152 - $1^{\circ}$ andar Cascadura

Capital - Fórum Regional do Méier - Rua Aristides Caire, 53 - Méier

Capital - Fórum Regional da Pavuna - Avenida Sargento de Milícias, s/n ${ }^{\circ}$ - $2^{\mathbf{o}}$ andar Pavuna

Capital - Fórum Regional de Santa Cruz - Rua Olavo Bilac, s/n $\mathrm{n}^{\circ} 2^{\circ}$ andar - Santa Cruz

Comarca de Belford Roxo - Avenida Joaquim da Costa Lima, s/n $\mathbf{n}^{\circ} 2^{\circ}$ andar - São Bernardo

Comarca de Duque de Caxias - Rua General Dionísio, 764 - Bairro 25 de Agosto - Duque de Caxias

Comarca de Niterói - Rua Coronel Gomes Machado, s/nº - Centro - Niterói

Comarca de Nova Iguaçu - Rua Doutor Mário Guimarães, 968 - Bairro da Luz

Comarca de Nova Friburgo - Avenida Euterpe Friburguense, 201 - Sobrado - Centro

Comarca de Petrópolis - Avenida Barão do Rio Branco, 2001 - 2º Andar - Centro

Comarca de São Gonçalo - Rua Francisco Portela, 2814 - Fórum dos Juizados Especiais

Comarca de São João de Meriti - Avenida Presidente Lincoln, 857 - Centro

Comarca de Três Rios - Praça São Sebastião, 224 - $1^{\circ}$ Pavimento - Centro

Parágrafo Único Quando da indicação do caso para mediação, que dependerá do consentimento dos envolvidos, as partes e advogados deverão ser informados pelo Juízo de origem das características do trabalho, especialmente sobre a gratuidade e o caráter sigiloso.

Art. $2^{\circ} \mathrm{O}$ centro de mediação será dirigido por Juiz de Direito, nomeado pela Presidência do Tribunal de Justiça.

Art. $3^{\circ}$ A Presidência do Tribunal de Justiça, por indicação do Juiz de Direito Diretor do centro de mediação, designará servidor devidamente capacitado em mediação para exercer a função de Coordenador, sem prejuízo de suas demais funções, nem de sua lotação, a quem competirá:

I - organizar as equipes de mediação;

II - promover os rodízios de mediadores entre as equipes, conforme o $\$ 3^{\mathrm{a}}$ do art. $4^{\mathrm{o}}$; III - informar mensalmente ao Departamento de Apoio aos Órgãos Colegiados Nãojurisdicionais - DEACO, até o dia 10 do mês subseqüente, as horas de observação, comediação e mediação do seu quadro de mediadores; 
IV - acompanhar o quadro de controle de processos atualizado mensalmente pelo apoio administrativo, informado ao Juiz de Direito Diretor;

Art. $4^{\circ}$ As equipes de mediação serão compostas por mediadores designados por Portaria do Juiz de Direito Diretor, dentre aqueles que necessariamente estiverem inseridos no processo de certificação, regulamentado pelo E. Órgão Especial, pela Resolução $n^{\circ}$ $\underline{19 / 2009}$, após consulta a Presidência do Subgrupo de Trabalho para Conciliação e Mediação do Tribunal de Justiça do Estado do Rio de Janeiro.

$\S 1^{\circ}$ A consulta prévia deverá ser encaminhada ao endereço eletrônico do DEACO gabpresdeaco@tjrj.jus.br, dirigida a Presidência do Subgrupo, com a relação dos nomes dos mediadores a serem designados.

$\S 2^{\circ} \mathrm{O}$ DEACO irá certificar se os candidatos participaram do curso básico de formação em mediação, submetendo os nomes à aprovação da Presidência do Subgrupo. Os nomes aprovados serão informados por correio eletrônico ao Juiz de Direito Diretor do respectivo Centro de Mediação, a fim de possibilitar a edição da Portaria de designação.

$\S 3^{\circ}$ A designação das equipes se fará, preferencialmente, em rodízio, observando-se a disponibilidade de horários e sua adequação às necessidades das partes.

Art. $5^{\circ}$ A Direção do Fórum a que estiver vinculado o centro de mediação prestará o apoio administrativo necessário para o seu bom funcionamento, que consistirá, entre outros, nos serviços de:

I - recepção;

II - atendimento telefônico;

III - controle de processos referentes à mediação, por planilha própria, aprovada pelo Subgrupo de Trabalho;

IV - agendamento de sessões de mediação ou de outros atendimentos;

V - controle de material, formulários, dos vídeos institucionais e de sua transmissão;

Art. $6^{\circ}$ O Subgrupo de Trabalho para Conciliação e Mediação, por intermédio do DEACO, prestará apoio técnico-administrativo aos centros de mediação e mediadores, 
inclusive, recebendo diretamente dos mediadores os concernentes relatórios de mediação, encaminhando-os aos mediadores supervisores.

Art. $7^{\circ}$ Quaisquer dúvidas acerca dos procedimentos concernentes a mediação que não estejam regulamentadas por este Ato Executivo serão dirimidas pelos Presidentes do Grupo de Trabalho de Soluções Alternativas para Busca de Resolução de Conflitos e do Subgrupo de Trabalho para Conciliação e Mediação do Tribunal de Justiça do Estado do Rio de Janeiro.

Art. $8^{\circ}$ Sob a presidência do Juiz de Direito Diretor designado, a Direção do Fórum a que estiver vinculado o centro de mediação lavrará a Ata de Instalação, remetendo cópia à Presidência do Tribunal de Justiça e à Corregedoria-Geral da Justiça.

Art. $9^{\circ} \mathrm{O}$ presente Ato entrará em vigor na data da sua publicação, revogando as disposições em contrário.

Rio de Janeiro, 15 de abril de 2010.

DESEMBARGADOR LUIZ ZVEITER PRESIDENTE 
Rio de Janeiro, 17 de dezembro de 2009.

Desembargador LUIZ ZVEITER

Presidente

id: 761076

RESOLUÇÃO No $19 / 2009$

Dispõe sobre a regulamentação da atividade de Mediação no âmbito do Poder Judiciário dp Estado do Rio de Janeiro.

O Órgão Especial do Tribunal de Justiça do Estado do Rio de Janeiro, no exercício de suas atribuições legais e regimentais, e tendo em vista o decidido na sessão de 14 de dezembro de 2009 (Processo 2009-287748),

CONSIDERANDO que o Estado brasileiro adotou solenemente em sua Carta Magna a solução pacífica dos conflitos, como um dos princípios regentes das relações entre os povos, sendo objetivo fundamental da República a construção de uma sociedade livre, justa e solidária;

CONSIDERANDO que a mediação tem por escopo a otimização da solução dos conflitos, a prevenção de litígios, a inclusão social pela valorização do ser humano e pelo respeito aos direitos fundamentais;

CONSIDERANDO os princípios contidos na Lei Federal nº 9.307, de 23 de setembro de 1996, que dispõe sobre a arbitragem;

\section{RESOLVE:}

Art. $1^{0}$ Para fins desta resolução, mediação significa um processo por meio do qual uma terceira pessoa neutra, denominada mediador, atua encorajando ou facilitando a resolução de uma disputa entre duas ou mais pessoas, físicas e/ou jurídicas, de modo informal e não adversarial, com o objetivo de auxiliar as partes disputantes a alcançarem um acordo mutuamente aceitável e voluntário. Em mediação, a autoridade decisória é das próprias partes e a tarefa do mediador inclui, mas não se limita a isso, a de ajudar as partes a identificarem questões e interesses subjacentes à lide a serem resolvidos em comum, bem como alternativas de acordos.

Art. $2^{\mathbf{0}}$ A mediação pode ter lugar antes mesmo da distribuição da ação e ainda que na pendência de recursos interpostos pelas partes, e não se limita aos processos de natureza civil, aí incluídas, preferencialmente, as questões referentes a consumo, família, a relações de vizinhança e todas as demais de trato continuado, mas se estende, também, às ações penais privadas; às públicas que versem sobre infrações de menor potencial ofensivo ou não, quando sujeitas a representação; às públicas incondicionadas de 
infrações de menor potencial ofensivo quando houver vítima direta, sujeita, entretanto, à apreciação do MP e do Juiz a aceitação do acordo como forma de encerramento do processo por falta de justa causa, e bem assim às demais ações penais públicas, como cláusula ou condição de eventual suspensão do cumprimento da pena ou do processo.

$\S \mathbf{1}^{\mathbf{0}}$ As questões de família acima mencionadas, se referem tanto às que resultam do matrimônio, como das uniões, estáveis ou não, antes e depois da dissolução do vínculo matrimonial ou da união, envolvendo divisão de bens, custódia partilhada, ou não, dos filhos, alimentos, visitação, e outras questões emocionais e/ou financeiras usualmente não consideradas no sistema heterocompositivo;

$\S 2^{\mathbf{0}}$ Sendo facultativa, como é, a assistência, se uma das partes comparecer assistida por advogado, a outra, se quiser, terá assistência judiciária prestada, se for o caso, pela Defensoria Pública, cabendo ao mediador estimulá-los a participarem do processo autocompositivo, esclarecendo-os a respeito da mediação, das possibilidades da autocomposição e das dúvidas que eventualmente tenham.

Art. $3^{\mathbf{o}}$ Toda e qualquer mediação será necessariamente conduzida segundo as técnicas e procedimentos próprios da mediação, por mediador certificado pelo Tribunal de Justiça do Estado, depois da frequência ao respectivo curso, com aproveitamento aferido por testes teórico e prático, na forma do que dispuserem as diretrizes para certificação de mediadores do TJRJ.

Parágrafo Único - Na hipótese de mediação não voluntária, o respectivo procedimento não poderá superar o período de quarenta e cinco dias, prorrogáveis a critério do juiz ou do relator, durante o qual ficará suspenso o respectivo processo, salvo se antes disso o mediador declarar impasse nas tratativas ou a impossibilidade de se chegar a um acordo.

Art. $4^{\circ} \mathrm{O}$ mediador estará imune a qualquer tipo de responsabilização, civil ou criminal decorrente do respectivo procedimento, salvo as hipóteses de má-fé, propósito malsão, conduta imprópria ou de desrespeito aos direitos fundamentais, à segurança ou à propriedade das partes ou de terceiros.

Art. $5^{\circ}$ A mediação será necessariamente precedida de informações às partes e seus eventuais advogados, de modo a esclarecê-los suficientemente sobre o respectivo procedimento e objetivo, e obter-lhes, por escrito, o necessário assentimento.

$\S 1^{0}$ Comunicação, em mediação, significa uma declaração oral ou escrita, ou ainda, uma conduta não verbal, assertiva, entretanto, feita pelos participantes da mediação durante seu curso, ou mesmo antes, desde que ao escopo de apoiar ou facilitar a mediação, e despida de conteúdo ofensivo ou criminoso; 
§ $2^{\mathbf{0}}$ São participantes da mediação as partes ou a pessoa que atende à mediação por telefone, videoconferência ou outros meios eletrônicos. Partes, entretanto, são as que participam da mediação diretamente, ou ainda as pessoas que tenham interesse jurídico na solução da disputa, titulares de direito ou de posições jurídicas que possam ser afetados pela resolução do conflito;

$\S 3^{\mathbf{o}}$ Mediador é a Terceira pessoa, neutra e imparcial, que facilita o processo de mediação, de modo a eliminar os obstáculos à comunicação, identificar questões e explorar as respectivas alternativas de solução, sem, entretanto, indicar ou sugerir a resolução a ser tomada;

§ $4^{0}$ A mediação se inicia com a declaração de abertura e de sua aceitação pelas partes, e termina com a homologação judicial, quando necessária, do acordo total ou parcial por essas firmado no sentido da resolução da disputa, ou ainda com a declaração de impasse pelo mediador ou determinação de seu término pelo juiz ou relator do processo. Também porá termo à mediação plurissubjetiva, a declaração escrita de uma das partes endereçada às outras dando-lhes ciência do término de sua participação no procedimento.

Art. $6^{\circ}$ Toda comunicação em mediação será absolutamente confidencial, sendo defeso a seus participantes, eventuais supervisores e observadores, a revelação de seu conteúdo a qualquer outra pessoa que não a seus participantes. A violação dessa confidencialidade sujeitará os respectivos participantes, eventuais supervisores e observadores, às penas do artigo 154 do Código Penal, sem prejuízo da reparação razoável e equitativa dos danos eventualmente suportados pela(s) parte(s), nos termos da lei civil.

$\S \mathbf{1}^{\mathbf{0}}$ À parte na mediação é assegurado o direito de se recusar a testemunhar e o de impedir que outra pessoa o faça no procedimento subsequente, assim definido o da adjudicação judicial que se segue à mediação não exitosa. Tal prerrogativa é assegurada, também à parte que, em mediação plurissubjetiva, assim entendida a que se processa entre mais de duas pessoas, dela se retire mediante aviso escrito às demais partes, exclusivamente, entretanto, quanto às comunicações anteriores ao aviso;

$\S 2^{\circ}$ Não são confidenciais, todavia:

.os termos do acordo alcançado durante a mediação, salvo se em contrário dispuserem as partes;

.as comunicações a cujo respeito as partes a dispensem, bem como as que revelem o planejamento de crime, seu cometimento ou tentativa, ou atividade criminosa em progresso ou andamento;

.as comunicações reveladas ao intuito único e exclusivo de provar a má prática de atividade profissional ou de conduta inadequada ou imprópria no decorrer da mediação; 
§ $3^{\mathbf{o}}$ A confidencialidade da mediação entre marido e mulher ou companheiros, ou ainda entre profissionais e seus clientes, exceção feita a advogados e seus constituintes, não se aplica a nenhuma comunicação que em seu decurso revele abuso ou suspeita de abuso, abandono ou negligência de menor, e não se constituirá em fundamento para a recusa de detalhado relatório sobre o fato ou de colaboração com as autoridades no sentido da apuração do evento reportado.

Art. $7^{\mathbf{o}}$ Se as partes chegarem a acordo, parcial que seja, quanto às questões em debate, o mediador elaborará o respectivo termo e o submeterá às partes e seus advogados e somente depois de por esses aprovado, será encaminhado ao juiz ou ao relator do processo para a devida revisão e homologação, respeitados os limites que são postos ao poder dispositivo das partes pelos direitos fundamentais e demais princípios de ordem pública, éticos e morais a que se submete.

Parágrafo único - Toda informação proveniente de arquivos, relatos, sumários do caso, notas do mediador, ou qualquer outro material referente às informações obtidas no decurso do procedimento de mediação por qualquer de seus participantes, não poderão ser utilizadas por quaisquer deles, nem admitidas como prova em juízo ou fora dele, salvo as hipóteses dos parágrafos $2^{\circ}$ e $4^{\circ}$, do artigo anterior.

Art. $\mathbf{8}^{\mathbf{0}}$ A mediação poderá, a todo tempo, ainda que na pendência de recurso das partes, ser por essas voluntariamente solicitada, ou pelo juiz ou relator promovida (CPC, art. 125) a seu prudente critério, e eventualmente limitada a certa parte do conflito.

Parágrafo Único - Não poderão, entretanto, ser objeto de mediação, os conflitos em que um dos participantes não demonstre interesse no procedimento, careça de capacidade intelecto volitiva necessária à negociação, verse sobre fato tipificado em lei como crime de ação penal pública incondicionada, ressalvadas as hipóteses previstas na parte final do artigo $2^{\circ}$ desta Resolução, e as ações de habeas corpus.

Art. $9^{\circ}$ Em no máximo 05 (cinco) dias após o encaminhamento do caso à mediação, o mediador designado procederá à notificação das partes para a primeira conferência em dia, hora e local que fixar, a menos que a autoridade judicial que o encaminhou já os tenha ela própria, designado.

$\S 1^{\mathbf{0}}$ As partes podem, em 05 (cinco) dias, contados do respectivo encaminhamento do caso à mediação, requerer a respectiva dispensa se a questão em debate já tiver sido antes mediada entre as mesmas partes; a questão for unicamente de direito ou se algum motivo relevante a impeça de participar da mediação. Da decisão do juiz ou relator do processo que solver tal pedido não caberá recurso de espécie alguma;

$\S 2^{\circ}$ É também assegurado às partes, no mesmo prazo de 05 (cinco) dias contados do encaminhamento do caso à mediação, ou da superveniência do motivo incapacitante, o 
direito de impugnar o mediador designado que se sujeita desde logo às causas de suspeição e impedimento previstas no Código de Processo Civil;

$\$ 3^{\mathbf{0}} \mathrm{O}$ mediador, durante todo seu desenrolar, deve estar no controle do procedimento de mediação, permitida, entretanto, aos advogados das partes a comunicação reservada com seus clientes. Entretanto, sob a discrição do mediador e desde que com o assentimento das partes, o procedimento de mediação pode desenrolar-se na ausência de seus advogados, salvo se ao contrário houver determinado o juiz ou o relator do processo;

$\$ 4^{\mathbf{0}}$ No desempenho de suas relevantes funções, o mediador está sujeito à observância do respectivo código de ética, orientado pelos princípios da voluntariedade, eticidade, boafé, confidencialidade e competência, sujeitando-se, além de à reparação dos danos eventualmente causados às partes, à perda da respectiva certificação. Ao mediador é absolutamente defeso orientar as partes a respeito de questões jurídicas, prerrogativa exclusiva dos advogados que eventualmente as assistam;

$\S \mathbf{5}^{\mathbf{0}} \mathrm{O}$ exercício das funções de mediador certificado, por período contínuo superior a um ano, constitui relevante serviço público a ser anotado nos assentamentos funcionais de servidor, além de título em concurso público realizado no âmbito do Poder Judiciário do Estado, inclusive no de provas e títulos para ingresso na magistratura de carreira estadual e critério de desempate nesse, ou em qualquer concurso realizado por esse Poder. Quando exercida por bacharel em direito, é também considerada atividade jurídica para os fins de que cuida o artigo 58, da Resolução $\mathrm{n}^{\circ}$ 75, de 12 de maio de 2009, do Conselho Nacional de Justiça, desde que exercida por, no mínimo 16 (dezesseis) horas mensais, no período de 1 (hum) ano;

$\S 6^{\circ}$ É defeso ao juiz ou relator do processo, ainda quando mediador certificado, proceder a mediação dos casos que lhe estejam submetidos à respectiva jurisdição.

Art. 10 Sem prejuízo de outras disposições a propósito do tema, é requisito para candidatar-se à certificação como mediador a formação em nível superior de ensino.

$\S \mathbf{1}^{\mathbf{0}}$ Ao escopo de proteger os participantes da mediação e como salvaguarda do sistema judicial, o candidato à certificação deve exibir vida anteacta funcional e/ou pessoal sem anotações desabonadoras, desqualificando-o desde logo, condenações criminais anteriores ou sobrevindas à certificação, pelo menos enquanto não reabilitado nos termos da lei penal;

$\$ 2^{\mathbf{0}}$ Os mediadores certificados pelo Tribunal e estranhos a seus quadros, prestarão pelos menos 150 horas de mediação a título de reembolso dos ativos despendidos na respectiva formação. 
Art. 11 O Presidente do Tribunal de Justiça poderá criar Centros de Mediação, compostos por um juiz coordenador, e por, no mínimo, quatro mediadores, desde que todos devidamente certificados pelo Tribunal de Justiça, podendo extingui-los, depois de ouvido o Órgão Especial.

$\S 1^{\mathbf{0}}$ Os Centros de Mediação, que terão Regimento Interno vinculado aos termos desta Resolução, a ser elaborado pelo Grupo de Trabalho de Soluções Alternativas para Busca de Resolução de Conflitos do Tribunal de Justiça do Estado do Rio de Janeiro, Subgrupo de Mediação, serão montados em espaço próprio dos fóruns das Comarcas-sedes, e se comporão, na medida do possível, de pelo menos 3 (três) salas de mediação, mobiliadas com mesas redondas, que deverão dispor de som ambiente, antessalas de espera, e uma sala de suporte administrativo, no formato indicado pelo Grupo de Trabalho de Soluções Alternativas para Busca de Resolução de Conflitos, da Presidência do Tribunal.

§ $2^{\mathbf{0}}$ Além da mediação em si mesma, caberá aos Centros da Mediação a promoção de palestras, conferências, painéis, cursos de fim-de-semana, destinados à educação comunitária, à formação e multiplicação de mediadores, bem como programas de reinserção social de menores e de condenados pela prática de infrações de menor potencial ofensivo; de condenados que se encontrem em cumprimento de pena sob o regime aberto ou em livramento condicional, ou mesmo em período de suspensão de execução de pena, e de réu de processo suspenso em decorrência de transação penal;

$\S 3^{\text {o }}$ Incumbirá também aos Centros de Mediação, a formação de mediadores comunitários, com atuação, de preferência, nas comunidades a que pertencem sob a supervisão direta do Subgrupo de Mediação, do Grupo de Trabalho de Soluções Alternativas para Busca de Resolução de Conflitos do Tribunal de Justiça do Estado do Rio de Janeiro, que deles se utilizará, assim como de juízes mediadores, nos eventos de Justiça em Ação, Itinerante e similares.

Art. 12 Os mediadores voluntários formados por outras Instituições de ensino, serão avaliados e certificados pelo Tribunal de Justiça a partir do respectivo histórico escolar, consideradas as informações dos juízes junto aos quais vêm exercendo tal função, e se submetem às disposições desta resolução, especialmente às que dizem respeito ao exercício da mediação e suas consequências civis e criminais, estas por força do artigo 327 do Código Penal.

Parágrafo Único - Divergindo o conteúdo programático dos respectivos cursos de formação, com o do ministrado pelo Tribunal de Justiça, serão eventualmente submetidos a testes teórico e prático que os habilite à certificação e, quando necessário, à frequência, com aferição de aproveitamento, ao Curso de Formação de Mediadores do Tribunal de Justiça. 
Art. 13 Nos projetos de construção e/ou reforma dos edifícios dos Fóruns estaduais, será necessariamente previsto e reservado espaço para montagem de Centro de Mediação, no formato a ser indicado pelo Grupo de Trabalho de Soluções Alternativas para Busca de Resolução de Conflitos, da Presidência do Tribunal.

Art. 14 Esta Resolução entrará em vigor na data da sua publicação, revogadas as disposições em contrário.

Rio de Janeiro, 17 de dezembro de 2009.

Desembargador Luiz Zveiter

Presidente 


\section{Entrevista realizada em 05/05/2010 com o Juiz Joaquim Domingos de Almeida Neto do 9o Juizado Especial Criminal da Comarca da Capital do Rio de Janeiro.}

Em termos de Mediação Penal dentro do JECRIM (pois não tenho experiência quanto a este processo dentro de Vara Criminal) no meu sentir, realizamos dois tipos de mediação: uma mediação realmente penal, ou seja, que influencie em questões de pena, e uma mediação civil dentro de um Juizado Criminal, que é o que também se faz mais corriqueiramente aqui e no Brasil inteiro, pelo o que eu sei.

Eu faço essa distinção porque, $1^{\circ}$ quando você fala em Mediação Penal, me leva a pensar muito em justiça restaurativa, em círculos de restauração entre ofensor e vítima visando a questão criminal mais especificamente.

A Lei $n^{\circ}$ 9099/95 dá autorização para que eu possa realizar um acordo civil com efeitos penais, e que afasta totalmente a jurisdição penal. Então, na verdade o que se faz dentro de um JECRIM, é mediação civil com alguns efeitos de eliminar o processo penal também. Assim, não ocorre diretamente uma Mediação Penal tal como é descrito nos livros.

O que é usado mais em termos Justiça Restaurativa no JECRIM são as questão de drogas. Nós estamos tentando construir um modelo de audiência para drogas que seja: $1^{\circ}$ coletivo, $2^{\circ}$ que respeite os princípios da Lei ${ }^{\circ} 11.343 / 2006$, (a autonomia da vontade, tratamento sempre voluntário, responsabilidade individual) e $3^{\circ}$ procuramos afastar o estigma da Justiça Terapêutica, que ao meu ver é uma coisa muito negativa dentro do sistema penal brasileiro. Ao tentarmos transportar o modelo de Justiça Terapêutica norteamericano para o nosso modelo, encontramos uma serie de dificuldades, até mesmo constitucionais. Como por exemplo, eu não tenho como negociar no sistema brasileiro a culpa, já o sistema americano é possível.

O sistema americano quando fala em Justiça Restaurativa, pressupõe um sistema retributivo, se eu não cumpro as condições estabelecidas pelo juiz para tratamento, eu tenho como sanção a privação da liberdade. Se eu me submeto a testagem e não sou considerado "limpo" eu tenho como sanção a prisão. E tem prisões previstas pelo sistema americano que não são cabíveis no nosso sistema brasileiro.

Na Lei de Drogas Brasileiras (Lei no 11.343/2006) pressupõe voluntariedade, por isso que o sistema de Justiça Terapêutica não pode ser transplantado de lá pra cá. Não 
pode ser simplesmente importado tal como ele existe. Outra incoerência do sistema de justiça terapêutica norte-americano que eu vejo comparando ao nosso sistema, é que neste, tem-se como pressuposto que se o réu reincide e para mim, no caso do crime de drogas não ocorre a reincidência e sim, a recorrência do crime, pois é o mesmo crime que se repete.

Em termos de Justiça Retributiva, se o réu reincide, a sanção pela reincidência é o afastamento do tratamento. E na filosofia da Lei $\mathrm{n}^{\circ} 11.343 / 2006$, se você tem o reuso da droga, ou seja, eu estava usando e não consegui me manter "limpo" e fui preso novamente eu tenho a necessidade de um maior tratamento e não o afastamento do tratamento e desligamento do sistema, eu não posso voltar para o sistema retributivo.

Assim, o sistema que a Lei $n^{\circ} 11.343 / 2006$ prevê se confina muito mais com o sistema de Justiça Restaurativa que pressupõe utilizar a Justiça Criminal e a sua força simbólica para facilitar o tratamento e não para impedi-lo ou determiná-lo. Não é o juiz que vai tratar ou fixar o período de tratamento e não vai também condicionar o fim do processo penal à recuperação ou cura, pois não existe a cura em uso de drogas e álcool, existe se manter "limpo", em conseguir resistir a droga.

Nos casos de drogas eu tenha a Justiça Restaurativa muito mais presente com a Lei $n^{\circ} 11343 / 2006$, porque eu tenho que respeitar a vontade do usuário, eu não pressuponho abstinência para ter um tratamento (para isso, eu teria que internar a pessoa), e isso não seria eficaz.

Com isso, é um sistema muito mais próximo da Justiça Restaurativa. E ele é feito em uma audiência em conjunto, pois eu pude perceber que: $1^{\circ}$ ) por ser uma questão de economia de mão de obra, eu juiz, não tenho condições de fazer 300 audiências iguais. $\mathrm{Na} 3^{\mathrm{a}}$ audiência, por exemplo, o conteúdo que eu vou passar para a parte será muito inferior, mais simplificado. Então, eu faço audiências coletivas, para que eu possa disseminar o mesmo conteúdo para um número grande de pessoas; $2^{\circ}$ ) eu tenho interação com os usuários de drogas. Os usuários também passam a ver que seu problema é também da sociedade, deve ser tratado dentro da sociedade e que tem tratamento, pois o individuo ao seu lado vai aderir ao tratamento igualmente, porque ele também não conseguiria.

Assim, eu acho que a Mediação Penal poderia ser vista no processo de drogas. Eu inclusive já realizei uma intervenção mediadora ( seria muito ousado chamar de Mediação Penal). O caso tratava-se de uma família, composta por três irmãos que tinham recebido de herança um apartamento localizado em bairro privilegiado do Rio de Janeiro. 
No apartamento viviam três irmãos, uma menina, (a mais velha) que tinha um filho, o irmão do meio e o menor que tinha um problema mental associado ao uso da droga. $\mathrm{O}$ irmão do meio fazia uso moderado de droga, inclusive convidando pessoas para dentro do apartamento para consumir. E a Mediação Penal se deu nesse processo quase como redução de danos. O irmão do meio está cometendo um fato criminoso, a irmã tem um filho pequeno que não pode ser prejudicado pelo seu ato criminoso, e essa circunstância põe em risco permanente a entrada da policia entrar no apartamento e dizer que o local é um ponto de venda de drogas e sair todo mundo preso, inclusive a criança (filho da irmã mais velha) ser levado par um reformatório.

As condições da Mediação Penal foram feitas para favorecer essa entidade familiar a conseguir viver harmoniosamente dentro do apartamento que era de propriedade dos três, (pois nenhum deles queria se desapossar do apartamento) e também, que eles tentassem se engajar em algum tipo de tratamento para melhorar o uso da droga e se comprometessem, os três irmãos juntos, de não trazer a droga para dentro do apartamento, porque isso prejudicava o irmão que era doente mental e prejudicava a irmã que tinha um filho pequeno. Essa Mediação Penal foi feita no intuito de que o processo fosse arquivado pelo Ministério Público. Nesse caso eu tinha ameaça entre os irmãos, lesão corporal e tinha a posse de drogas para uso próprio. Eu (Juiz) tentei dar uma roupagem de mediação civil, porque na verdade a Mediação Penal incluiu a redução dos danos e o final do processo foi o seu arquivamento sem resposta penal, pois a civil foi suficiente.

Agora no caso aqui do JECRIM Barra da Tijuca eu faço uma mediação civil, dentro de um espaço que é penal. Exemplo: mediação civil sobre reparação de danos e acidente de trânsito. Não é uma Mediação Penal, só seria se eu fizesse um processo de mediação em que a vítima dissesse se sentir confortável pelo cumprimento de uma determinada pena pelo seu ofensor, por exemplo, a realização de trabalhos voluntários em um determinado local e em um determinado período, para que ele pudesse enxergar os malefícios causados. E também seria necessário uma assunção de culpa por parte do ofensor, ou seja, ele assume o fato criminoso que fez e por isso, vai reparar o dano causado, prestando serviços à comunidade. Essa seria a Mediação Penal clássica.

No caso da transação penal para ser uma Mediação Penal, seria necessário a presença da vítima acordando junto com o réu e o Ministério Público. A transação penal não é Mediação Penal, é o acordo do Ministério Público com o réu. Existe espaço para a Mediação Penal, mas não é utilizado com frequiência. 
O que se faz dentro do processo de Mediação Penal realizada no JECRIM, é uma mediação civil dentro do espaço penal, pois eu acordo danos entre autor do fato e vítima. Exemplo: vc bateu no meu carro e eu fiquei um mês sem poder ir trabalhar, tive um prejuízo grande, meu carro está no conserto até hoje, então tenta-se compor civilmente este litígio através da mediação. No entanto, não terei uma série de características que Mediação Penal demanda, por exemplo: assunção de culpa.

O que ocorre é uma mediação civil, em que eu extingo a punibilidade, conseqüência do acordo civil e termino com o processo evitando também um processo na Vara Cível.

Nos casos de vizinhança, também fica nítida a necessidade da mediação. Eu tenho uma relação continuada em que há necessidade de se estabelecer novas formas de convivência. Esse é o objeto da mediação. Mas esta não deixa de ser uma mediação civil também entre partes. Esses casos, também poderiam ser realizados através da mediação no Juizado Cível, em um Programa Comunitário ou em um espaço criminal. Reafirmo, não há assunção de culpa, ou caráter de pena, que se afasta da Mediação Penal, mas é mediação clássica civil, que estabelece regras para o futuro, regras de convivência, uma relação continuada, tudo se adéqua à mediação.

Vou resolver meu processo criminal através de um acordo civil, extinguindo a punibilidade e vou evitar o processo civil também.

Nos casos de relacionamentos familiares, desobediência e visitação é um crime de ação penal pública incondicionada. Muitos vão dizer que não é crime, não existe crime de desobediência sobre uma ordem judicial, mas eu tenho a possibilidade de estabelecer um novo relacionamento para aquele casal parental que não consegue se entender, que não foi resolvido na Vara de Família (deveria ter sido realizada a mediação para o caso nessa esfera) e não foi feito, o que acaba levando a realização de uma mediação familiar em um espaço criminal.

Como o processo de mediação é um recurso muito escasso, nós privilegiamos os casos de relações continuadas, familiares, vizinhança, crimes de desobediência, ou até relações societárias.

Na Barra da Tijuca (R.J.) temos muitos casos de empresas, familiares ou não, que não conseguem resolver a solução de sua sociedade ou a nova forma de encarar a sociedade, (exemplo no caso de sucessão por morte de algum sócio fundador), o caso chega ao JECRIM geralmente por crimes de ameaça ou contra a honra. 
A triagem é feita pelo juiz ou pelo conciliador na sala de conciliação, a proposta é feita às partes e dependendo da aceitação, são encaminhadas à mediação.

A duração das sessões é variada, depende de cada caso, há mediações em que o problema é resolvido na $1^{\mathrm{a}}$ sessão e já ocorreu mediação de seis meses de duração, pois as partes resolveram estabelecer no curso da mediação um teste de realidade, ou seja, estabeleceram um acordo parcial e o processo ficou suspenso aguardando aquele acordo parcial. Depois de testado o acordo parcial pelas partes, puderam ver que existia a confiabilidade entre eles. Passado um tempo, a sessão de mediação foi retomada e foi firmado um acordo, pois a confiança foi confirmada entre as partes e o acordo inclusive foi ampliado para abarcar outros 5 processos que existiam na Vara de Família.

Se formos pensar em termos de um processo só, uma mediação que dura seis meses é realmente um período muito longo, no entanto, é um processo que vai resolver outros seis processos, por exemplo. Se formos dividir a duração do processo de mediação pelo número de processos em outras Varas, temos como resultado um mês para a resolução de cada um, o que é pouco tempo para um resultado que vai ser muito mais duradouro e eficaz que uma sentença dada por um juiz a cada um desses seis processos.

Só a aceitação das partes em participar do processo de mediação já é um primeiro acordo, seria o $1^{\circ}$ passo da mediação, até mesmo antes da pré-mediação. A aceitação da idéia da mediação é uma etapa muito importante, pois no Brasil é uma idéia nova, o brasileiro não conhece esses procedimentos, tornando muito difícil seu emprego em nosso país.

No Brasil, não há qualquer tipo de freio às solicitações no Judiciário. Diferentemente do que ocorre, por exemplo, nos Estados Unidos, em que a mediação evoluiu muito. A voluntariedade não é tão grande como a que ocorre no Brasil, pois lá, ou o indivíduo participa da mediação ou terá que desembolsar um valor muito alto para abrir uma ação. Se a pessoa não tem dinheiro para entrar com a ação, a única solução que lhe resta é participar da mediação para obter alguma resposta. Essa voluntariedade de certa maneira é domada, diferentemente do que ocorre no Brasil, para se "vender" a mediação, é necessário mostrar a parte que apesar deste processo não ser sempre o mais econômico, o mais rápido, é o mais adequado para o tipo de demanda em questão.

$\mathrm{Na}$ cultura brasileira estamos acostumados a viver sob a tutela de nossos pais, de nosso marido e etc; e de repente dá-se a oportunidade de resolver a sua vida de acordo com a sua vontade, é um choque cultural muito grande. O indivíduo geralmente não quer decidir, prefere que o juiz faça por ele, ele é quem tem que dizer o que eu devo fazer. 
Exemplo: Não vou estabelecer em conjunto com o meu ex-marido, o que é melhor para o meu filho ter convivência familiar, é o juiz que vai ter que dizer a maneira. Logo, implementar a mediação é algo culturalmente difícil no Brasil, pois temos um juiz constitucionalmente posto e, que tem que me receber, quer seja pela gratuidade de justiça, quer seja pela ação coletiva, quer seja por Juizado Especial, que não tem custas, múltiplas portas estão abertas.

A mediação seria mais uma porta que se abre, mas vender essa opção aqui no Brasil é muito difícil. A cultura do Brasil é de terceirizar o conflito, meu pai resolve, o padre resolve, a escola resolve. Quando a parte aceita em pensar nessa idéia, já é o $1^{\circ}$ acordo obtido pela mediação. A meu ver, seria interessante também, quantificarmos nas pesquisas sobre mediação no Brasil, quantas pessoas aceitaram chegar numa sala e conversar com o mediador, mesmo que eles não aceitem ir para a mediação depois. Mas só o fato deles se disporem a tentar e deixar em segundo plano a decisão do juiz, já é um passo para a mediação.

O processo de Mediação Penal não poderia influenciar na pena, porque a mediação é cercada de sigilo, tudo que aconteceu lá, ninguém pode saber. Não se sabe quem se recusou a continuar, justamente para não influenciar o juízo alguma simpatia ou antipatia. A mediação pode ter sido desconsiderada porque o réu é intolerante, por exemplo, mas fora do contexto mediação nunca se terá essa informação devido ao sigilo. Se o juiz sabe desse dado, por exemplo, seria um motivo para que se exaspere a pena dele e não melhorar. Por isso, qualquer dado deve ser mantido em sigilo e não pode ser comunicado de maneira nenhuma com o processo.

O que se faz no JECRIM quando uma mediação não teve sucesso é apenas informar que aquele processo de mediação não pode avançar. E não é informado o motivo pelo qual não se pode avançar com essa mediação, não se sabe se foi porque as partes não quiseram, ou se o mediador detectou algum ponto que não é possível ser mediado (Ex: abuso contra menor), ou simplesmente porque as partes abandonaram. A única informação é que a mediação não pode ser continuada, e deve ser retomado o processo exatamente no zero a zero, tal como foi para a mediação.

A tentativa de composição do dano vai influenciar a pena, pois uma das obrigações do réu condenado é de reparar o dano. Se eu estou diante de um processo penal tradicional na Vara Criminal, o espaço para mediação nesses casos é com a Suspensão Condicional do Processo, essa seria a Mediação Penal Típica, você tem uma denúncia que vai ser recebida e eu posso acordar (uma das condições da suspensão condicional do processo é a reparação de dano). 
Então, eu tenho instrumento legal pra chamar a vítima, colocar em uma sala de mediação com o ofensor e tentar mediar esse conflito. Várias coisas podem resultar daí, até a extinção da punibilidade, porque a vítima pode alegar que não tem necessidade deste determinado processo (e o processo é sujeito a representação), eu posso sair também com um acordo parcial com relação a indenização que o juiz tem que fixar. (Ex: se tive meu celular furtado, quero como indenização o ressarcimento do valor do aparelho - Vitima) (Um dos pressupostos da suspensão condicional do processo é a reparação do dano.)

Ou então, a vítima pode ser representante de vendas e o furto do seu celular não lhe causou apenas o prejuízo do aparelho, mas atrapalhou também a sua vinda inteira, pois todos os contatos de venda que o indivíduo tinha estavam naquele celular e para ele, o ressarcimento de dano é poder dizer isso para o seu ofensor e ele assumir que causou esse prejuízo para vítima e sua família. Isso seria uma Mediação Penal clássica. Ou então, poderia ser exigido apenas um valor simbólico de ressarcimento, uma reparação moral, por exemplo, a vítima quer que o ofensor vá até uma determinada instituição de caridade e faça determinada ação durante um determinado tempo, renunciando ao dano cível.

Nos crimes mais graves, homicídio, estupro, roubo. Também existe a obrigação de indenizar que é feita na sentença condenatória (o que é muito difícil para o juiz fixar). No crime de roubo, vou fixar apenas o dano moral. Existe espaço para a Mediação Penal nesses casos também (seu uso é irrestrito), mas é claro que ela nunca vai substituir ou influenciar a pena, ela vai ter que vir depois de uma sentença condenatória para tratar dessa questão pontual da satisfação da vítima, moral e até mesmo de contato, conversas.

A aplicação da Mediação Penal nesses casos, durante o processo, a meu ver não há muito espaço processual, somente se ocorrer a suspensão condicional do processo. Dentro do processo ordinário, sumário, o rito é muito concentrado, ocorre logo a A.I.J.(Audiência de Instrução e Julgamento), portanto, não se tem espaço processual para aplicação da mediação. O que pode ocorrer é depois da condenação, o juiz fixar na sentença que a decisão(ele pode até consultar as partes quanto a possibilidade de se mediar a indenização na mediação) quanto ao valor da indenização será fixado em mediação pelas partes. Mas ai já foi dado a sentença.

A aplicação do processo de mediação nesses casos é vislumbrado por mim, apenas depois da sentença. Diferentemente do que ocorre nos casos de JECRIM, pois o espaço é amplo, já o processo da Vara Criminal apesar de ser grande dentro da suspensão condicional, é pequeno dentro dos crimes de maior potencial ofensivo. Quanto menor a 
disponibilidade da vítima, menor a possibilidade de mediação e mais rígido o processo. No $9^{\circ}$ JECRIM (Barra da Tijuca) a vítima está em quase total disponibilidade.

A equipe de mediação é composta por voluntários e servidores voluntários do tribunal. Por ser voluntária, a mediação ocorre de quinze em quinze dias e a média são quatro sessões de mediação, se comparados a uma mediação privada o prazo seria de no máximo uma semana de trabalho.

Quando pensamos em uma Vara Criminal, em um Juizado Criminal, nós temos litígios que já estão bem cronificados, que já estão no final da linha. No IX JECRIM, nós fazemos um atendimento que deveria ter sido feito no inicio, na $1^{\mathrm{a}}$ reunião de condomínio que a pessoa reclamou que o carro estava mal parado na vaga, depois do barulho do salto, do filho que fazia barulho e assim, tudo passou a ser motivo de reclamação. Quando chega a ser registrado uma ocorrência criminal, o conflito já esta na fase final, cronificado. As pessoas precisam até mesmo de um tempo de maturação para ouvir o que o mediador falou para poderem refletir.

Não há nenhuma legislação com relação à Mediação Penal, só foi criado uma diretriz definindo quem é mediador. O TJ do RJ exige como mediador, pessoa capacitada, que tenha um acompanhamento constante, ou seja, capacitação permanente e uma supervisão para praticar a mediação dentro do Tribunal. O Tribunal do RJ pode se dar o luxo de dizer que tem o seu trabalho em dia e que a mediação não é solução para o Tribunal como substituto da conciliação para dar fim aos processos não julgados, mas sim, o TJ precisa da mediação para atender aos processos que é sabido que o instituto da mediação seria a mais indicada.

O fato da mediação não ter legislação ainda no Brasil é muito positivo, porque dá liberdade para se criar e o momento atual é de criação, não podemos engessar o processo, pois não sabemos até onde a mediação vai e o que é melhor pra mediação, seria muito cedo pra fazermos legislação. Caso fosse criado uma legislação seria necessário discutir meios de torná-la uma etapa obrigatória do processo.

Só há voluntariedade se esta for informada, só se decide voluntariamente, soberanamente for sabido o que é a mediação. É necessário passar pelo processo para saber o que é mediação, uma obrigatoriedade de existir a fase para o Estado, advogados e partes conhecerem. Depois de escutar o que é este processo, poderá ser dito se quer ou não participar do processo, contudo, a fase de apresentação do processo permanece obrigatória. 
Para se fazer o trabalho já realizado no IX JECRIM não é necessário uma legislação, a lei já dá todos os amparos suficientes para isso. Além disso, no Brasil não se não tem mediadores capacitados para realização do processo em todos os campos.

Com relação a iniciativas de introduzir a Mediação Penal em uma justiça minorista (Ex: caso de menores de idade), esta não seria local para experiência, pelo contrario, é a justiça mais séria que existe, sendo um lugar para a aplicação de projetos sérios e não projetos pilotos. É muito perigoso se mexer com adolescente, mesmo que infrator, pois se tem um prazo muito curto de processo, vai de 14 anos à 21 anos e fazer algum tipo de improviso nessa fase é muito perigoso.

No processo civil não há nenhuma necessidade de legislação, se eu posso me divorciar no cartório, é claro que eu posso mediar isso e levar para escritura pública. Há o monopólio da jurisdição na Constituição para aquilo que é jurisdicional, Se as partes resolvem decidir sozinhas não precisando do Estado é um direito que se tem. Se as partes tem o direito de continuar o processo, também tem o direito de terminar.

O resultado da Mediação Penal visto no JECRIM é fantástico. A participação do indivíduo no processo já é um resultado muito positivo. 


\section{Entrevista realizada em 21/04/2010 com o Juiz Arthur Narciso de Oliveira Neto do XVI Juizado Especial Criminal da Comarca da Capital do Rio de Janeiro.}

Eu conheci a Mediação Penal através de um programa desenvolvido pela SENASP (Secretaria Nacional de Segurança Pública), um órgão do Ministério da Justiça, que promoveu no RJ um curso de capacitação de mediadores e teve como publico alvo juízes, defensores e promotores de justiça. Durante um fim de semana foram realizadas palestras e simulações, podendo se ter um contato com a mediação tanto na esfera teórica quanto na prática.

Depois, ainda promovido por este mesmo programa e ministrado também pela SENASP, ocorreu um outro curso, com maior uma duração (uma semana) com formações teóricas e práticas. O público alvo eram juízes, promotores e defensores, mas havia também a participação de policiais civis e militares, o que dava um aspecto interessante ao curso. Saliento que isso é possível pois, a mediação independe da formação anterior da pessoa. Esse programa teve como professores, Célia Passos, Tânia Almeida e Gabriela Asmar.

A idéia inicial desse programa era de realizar após a sua conclusão, um trabalho através de centros de mediação junto aos núcleos de $1^{\circ}$ atendimento da Defensoria Pública, contudo, o seu objetivo não foi atingido. Seu aspecto marcante foi o de ter plantado uma semente para que a mediação fosse abraçada e difundida. Foi por causa desse curso que muitos colegas meus resolveram implementar na Escola da Magistratura o fórum de estudos permanentes de resolução pacífica de conflitos que está em funcionamento desde então.

Depois pude participar de um curso em Brasília, promovido pelo Conselho Nacional de Justiça e pela Escola Nacional da Magistratura, com representantes dos Estados, voltados a formação de mediadores.

Foi a partir dessas experiências que surgiu a minha idéia de implementar o processo de mediação no XVI JECRIM. Na prática já tínhamos a pelo menos três anos, intervenções mediadoras. Já se fazia um arremesso de mediação com a equipe técnica. Esta equipe técnica em nosso Juizado, é formada por dois assistentes sociais e uma psicóloga (essa equipe já fazia uma intervenção mediadora, apesar de não seguir o formato da mediação.) e é compartilhada entre o XV JECRIM (Madureira), XVI JECRIM (Jacarepaguá)e IX JECRIM (Barra da Tijuca). 
A partir disso, desde abril de 2009, o XVI JECRIM (Jacarápaguá) decidiu realizar esse trabalho no formato de mediação, aproveitando essa equipe e outros servidores que passaram a ser formados pelo Tribunal. O Tribunal a partir do início do ano passado (2009) começou a formar mediadores com um curso de duração de uma semana promovido para servidores do próprio quadro. A grande maioria dos servidores que procuraram esse curso foram assistentes sociais e psicólogos, apesar de estar aberto a qualquer serventuário que se interessasse. Foram formados centenas de servidores como mediadores através desse curso desde o ano passado.

Os mediadores formados por esses cursos serão distribuídos pelos centros de mediação instalados nesta última $6^{\text {a }}$ feira (16/04/2010). Apesar dessas experiências realizadas nos Juizados Especiais Criminais de Jacarepaguá, da Barra da Tijuca, São João de Meriti, Ilha do Governador e de Petrópolis serem ainda embrionárias, passaram a ser chanceladas pelo Tribunal, com a instalação no dia 16/04/2010 dos centros de mediação. Esses centros criados destinam-se inicialmente as Varas de Família e aos Juizados Criminais, mas a idéia é que eles atendam a todos os juízos da sua área de abrangência a medida que forem se estruturando para tanto.

Contudo, aqui no XVI JECRIM de Jacarepaguá, nós começamos a fazer desde abril de 2009 esse trabalho de intervenção mediadora, passando a adotar o formato da mediação. Os mediadores trabalham em um sistema de co-mediação (presença de dois mediadores em cada sessão) e um observador. As sessões são quinzenais, com duração aproximadamente de 3 horas por sessão e previsão de duração de todo o trabalho de 2 meses, mas podendo ser prorrogado de acordo com a necessidade.

A triagem dos casos que serão levados a tentativa de mediação é feita pelos juízes.

O Núcleo de Mediação de Jacarepaguá abrangia tanto o Juizado Criminal como as quatro Varas de Família. Foi combinado pelos juízes que integram esse núcleo que eles mesmos fariam essa triagem, pois a capacidade de atendimento é muito limitada.

No XVI JECRIM (Jacarepaguá) nós temos em torno de 3.000 processos com uma entrada mensal em média de 300 novos procedimentos, e uma capacidade limitada do Centro de Mediação, devido à especialização e voluntariedade do trabalho. Assim, os juízes optaram, por selecionar os casos em que o processo de mediação seria o meio mais indicado, por isso, a triagem é feita por eles mesmos, nas audiências especiais ou nas audiências de instrução e julgamento.

Os juízes aproveitam a audiência, (em que se detecta a necessidade daquele caso para a mediação), para fazer também uma exposição de como o trabalho será 
desenvolvido. É como se fosse aproveitado esse mesmo momento para se fazer uma espécie de audiência de pré-mediação sem prejuízo dessas explicações serem renovadas na $1^{\mathrm{a}}$ sessão de mediação. É como se os juízes realizassem uma "pré pré" audiência de pré mediação.

Os juízes procuram deixar de maneira bem clara que a mediação só acontece se ela for do consentimento das pessoas. Em momento algum ela é imposta, é claro que procuramos persuadir de uma certa maneira, mas em momento algum ela é imposta. Só há mediação se houver a aceitação de ambos os envolvidos.

Nesta oportunidade, são mencionados certas características que envolvem o processo de mediação, tais como: a gratuidade, o lugar em que será realizado o trabalho e o sigilo do processo são mencionados. É mito importante para as partes saberem que não irão precisar se deslocar para algum local para participar dos procedimentos. O processo de mediação tem um fim em si mesmo, as partes irão participar desse trabalho com o único objetivo de encontrar uma função autocompositiva, nada que for conversado com os mediadores será relatado para ser usado como informação. Então nesse $1^{\circ}$ contato, os juízes buscam prestar essas informações para as pessoas.

Essa prática do XVI JECRIM Jacarepaguá esta completando praticamente um ano e já temos 50 casos que foram encaminhados para a mediação.

$\mathrm{O}$ processo quando encaminhado à mediação, fica suspenso enquanto durar o trabalho. É explicado para as pessoas que a previsão é de dois meses, mas que ele pode ser prorrogado a pedido do mediador. A suspensão é por tempo indeterminado, enquanto perdurar a mediação, mas geralmente a previsão é de dois meses para todo o processo.

Nós aqui no XVI JECRIM já obtivemos números bastante interessantes com relação a aplicação do processo de mediação. De todas as mediações realizadas, nós temos um índice de acordo de setenta por cento.

Nós procuramos indicar para a mediação única e exclusivamente os casos de relação continuada devido a restrita capacidade de atendimento do Núcleo de Mediação, procura-se portanto, selecionar bastante.

Basicamente aqui no Juizado (XVI JECRIM) os casos envolvem conflitos de relações de vizinhança e familiares. Em alguns casos essas duas relações até se confundem, ou seja, vizinhos que são da mesma família.

Com relação a repercussão da pena sobre os casos encaminhados a mediação ainda não foi possível criar um mecanismo de acompanhamento para saber qual efeito da 
mediação nos casos em que não se chegou até o fim ou não se conseguiu gerar algum tipo de acordo, pois ainda é um trabalho embrionário. Mas o índice de composição é muito elevado.

No caso de não haver acordo no processo de mediação, o caso volta novamente ao procedimento da justiça tradicional. Mas isso não quer dizer que o caso vá chegar a julgamento, pois no JECRIM, além da possibilidade de acordo há a possibilidade de transação penal.

No XVI JECRIM Jacarepaguá eu diria que a proporção de processos que chegam até o julgamento de mérito efetivo não deve ultrapassar 5\%, o índice é bem reduzido e ainda dentre esses $5 \%$, dois terços dos casos geralmente são de réu revel, pois na maioria esmagadora dos casos ou ocorre denúncia, ou ocorre acordo ou a transação penal. 